\title{
Development of High Waste Loading Glasses for Advanced Melter Technologies
}

\section{D.K. Peeler \\ T.B. Edwards \\ C.C. Herman \\ R.J. Workman \\ I.A. Reamer}

Westinghouse Savannah River Company

Savannah River Technology Center

Aiken, South Carolina

\section{J.D. Vienna \\ J.V. Crum \\ D.E. Smith \\ D.S. Kim}

Pacific Northwest National Laboratory

Richland, WA

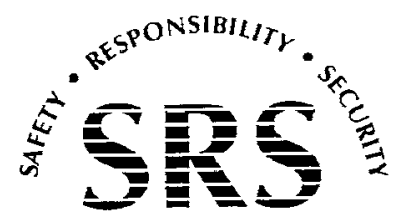


This document was prepared in conjunction with work accomplished under Contract No. DE-AC09-96SR18500 with the U. S. Department of Energy.

\section{DISCLAIMER}

This report was prepared as an account of work sponsored by an agency of the United States Government. Neither the United States Government nor any agency thereof, nor any of their employees, makes any warranty, express or implied, or assumes any legal liability or responsibility for the accuracy, completeness, or usefulness of any information, apparatus, product or process disclosed, or represents that its use would not infringe privately owned rights. Reference herein to any specific commercial product, process or service by trade name, trademark, manufacturer, or otherwise does not necessarily constitute or imply its endorsement, recommendation, or favoring by the United States Government or any agency thereof. The views and opinions of authors expressed herein do not necessarily state or reflect those of the United States Government or any agency thereof.

This report has been reproduced directly from the best available copy.

Available for sale to the public, in paper, from: U.S. Department of Commerce, National Technical Information Service, 5285 Port Royal Road, Springfield, VA 22161, phone: (800) 553-6847, fax: (703) 605-6900

email: orders@ntis.fedworld.gov

online ordering: http://www.ntis.gov/help/index.asp

Available electronically at http://www.osti.gov/bridge

Available for a processing fee to U.S. Department of Energy and its contractors, in paper, from: U.S. Department of Energy, Office of Scientific and Technical Information, P.O. Box 62, Oak Ridge, TN 37831-0062,

phone: (865)576-8401,

fax: (865)576-5728

email: $\underline{\text { reports@ adonis.osti.gov }}$ 


\title{
Development of High Waste Loading Glasses for Advanced Melter Technologies
}

\author{
D.K. Peeler \\ T.B. Edwards \\ C.C. Herman \\ R.J. Workman \\ I.A. Reamer
}

Westinghouse Savannah River Company

Savannah River Technology Center

Aiken, South Carolina

\section{J.D. Vienna \\ J.V. Crum \\ D.E. Smith \\ D.S. Kim}

Pacific Northwest National Laboratory

Richland, WA

This report was prepared by Westinghouse Savannah River Company (WSRC) for the United States Department of Energy under Contract No. DE-AC09-96SR18500 and is an account of work performed under that contract. 


\begin{tabular}{|c|c|c|c|}
\hline $\begin{array}{l}\text { Task Title: } \\
\text { High Waste Loaded Glasses }\end{array}$ & $\begin{array}{l}\text { ITS Task Number: } \\
\text { NA }\end{array}$ & $\begin{array}{l}\text { TTP Number: } \\
\text { SR16WT31, Subtask F }\end{array}$ & $\begin{array}{l}\text { TTP Date: } \\
\text { 10/15/2002 }\end{array}$ \\
\hline $\begin{array}{l}\text { Task Lead: } \\
\text { D.K. Peeler }\end{array}$ & Sigrature:y ledulu & $\begin{array}{l}\text { Organization: } \\
\text { ITS }\end{array}$ & $\begin{array}{l}\text { Date: } \\
10 / 1 / 02\end{array}$ \\
\hline $\begin{array}{l}\text { Task Lead: } \\
\text { J.D. Vienna }\end{array}$ & Signature: & $\begin{array}{l}\text { Organization: } \\
\text { PNNL }\end{array}$ & $\begin{array}{l}\text { Date: } \\
10 / 4 / 02\end{array}$ \\
\hline $\begin{array}{l}\text { Co-author: } \\
\text { C.C. Herman }\end{array}$ & $\begin{array}{l}\text { Signature: } \\
\text { Connul } C\end{array}$ & $\begin{array}{l}\text { Organization: } \\
\text { ITS } \\
\end{array}$ & $\begin{array}{l}\text { Date: } \\
10 / 1 / 02\end{array}$ \\
\hline $\begin{array}{l}\text { Co-author: } \\
\text { T.B. Edwards }\end{array}$ & Sighayure: $\mathrm{OCl}$ & $\begin{array}{l}\text { Organization: } \\
\text { SCS }\end{array}$ & Date: $1011 / 0^{2}$ \\
\hline $\begin{array}{l}\text { Technical Reviewer: } \\
\text { A.D. Cozzi }\end{array}$ & Signature: Cos' & $\begin{array}{l}\text { Organization: } \\
\text { ITS }\end{array}$ & Date: $10 / 1 / 02$ \\
\hline $\begin{array}{l}\text { Level 3 Manager: } \\
\text { E.W. Holtzscheiter }\end{array}$ & Signature: & $\begin{array}{l}\text { Organization: } \\
\text { ITS }\end{array}$ & Date: $10 / 102$ \\
\hline $\begin{array}{l}\text { Level } 4 \text { Manager: } \\
\text { S.L. Marra }\end{array}$ & Signature: 1 Mavon 0 & $\begin{array}{l}\text { Organization: } \\
\text { ITS }\end{array}$ & Date: $10 / 02$ \\
\hline
\end{tabular}




\section{Executive Summary}

Waste streams at the U.S. Department of Energy's (DOE's) Hanford and Savannah River sites contain a varied array of chemical compounds, a number of which can limit the waste loading or cause operating difficulties with melt rate or equipment corrosion. One such stream is the Hanford C-106/AY-102 High Level Waste (HLW) simulant which represents a blend of tanks that will be processed during initial HLW vitrification efforts at Hanford. The non-radioactive surrogate is based on a specific Hanford waste stream but will also provide valuable information to the Savannah River Site (SRS) - given the relatively high concentrations of $\mathrm{Fe}_{2} \mathrm{O}_{3}, \mathrm{Cr}_{2} \mathrm{O}_{3}$, and $\mathrm{Al}_{2} \mathrm{O}_{3}$ and the cross-cutting assessment of the strontium/transuranic (TRU) precipitation or permanganate-based pretreatment process being considered at both sites.

The vitrification programs at Hanford and Savannah River may benefit from higher temperature glass formulations that are processable in advanced melters (e.g., induction-heated, cold-crucible melter (ICCM)) or by changing the current liquidus temperature $\left(\mathrm{T}_{\mathrm{L}}\right)$ limit for Joule heated ceramic melters (JHCM).

The focus of this report was on the glass formulation activities in support of the ICCM and JHCM demonstrations with C-106/AY-102 simulant. The intent was to provide preliminary (non-optimized) glass formulations for a specific waste stream that met processing requirements, DOE product quality specifications, and programmatic objectives for the two melter types.

In general, the glasses developed (with waste loadings of $\geq 60$ mass $\%$ ) were very prone to devitrification (especially upon centerline canister cooling). The Product Consistency Test (PCT) response was primarily driven by the type and extent of crystallization and its ultimate impact on the residual glass matrix. Although the formation of nepheline was the primary suspect for the negative impact on durability in some glasses, its formation had little or no impact in other glasses - indicating that the residual glass matrix for each of these glasses is durable and acceptable.

One of the frit formulations, ICCM-2, was recommended to support initial ICCM demonstrations in Russia given the resulting glass (at 70 mass $\%$ waste loading) met all of the pre-defined acceptance criteria. The initial ICCM tests using ICCM-2 indicated potential processing difficulties. ${ }^{1}$ Circumstantial evidence from the test suggested that temperatures near the bottom of the melter were as low as $1100^{\circ} \mathrm{C}$, which caused crystallization of spinel and nepheline in significant concentrations.

Given these uncertainties, it was determined that a new formulation may need to be developed with a lower propensity for nepheline formation and, more importantly, a lower viscosity and lower slope of the logarithm viscosity vs. inverse temperature (increased length). ICCM-14 was developed to meet these requirements while maintaining a waste loading of 70 mass $\%$ and adequate processing and product quality properties. An additional frit, Aloy-3, was developed by researchers at the V.G. Khlopin Radium Institute (KRI) as a potential candidate for use in follow-on tests. Its composition and properties are similar to those of ICCM-14. The U.S. investigators recommended that either ICCM-14 or Aloy-3 be used on subsequent tests at KRI. Pending a review of their respective properties, researchers at KRI determined which glass was more suited for this technology.

\footnotetext{
${ }^{1}$ C.C. Herman, Meeting Minutes for Planning Meeting with Khlopin for High Alkaline Waste Testing, SRT-GPD2002-00107, August 13, 2002.
} 
With respect to supporting a JHCM demonstration, ICCM-13 (60 mass\% WL glass) was recommended, as this glass met all processing and product performance criteria. The high waste loadings in a JHCM for this particular waste stream can only be achieved by balancing the glass composition so that the crystal content in the melt is minimized (e.g., increasing $\mathrm{Na}_{2} \mathrm{O}$ and other alkali) while simultaneously minimizing the PCT release from $\mathrm{CCC}$ glass (e.g., reducing $\mathrm{Na}_{2} \mathrm{O}$ and other alkali). The recommendation was made in light of pre-existing knowledge of the potential for a limited amount of devitrification at the melt temperature $\left(T_{M}\right)$. This challenges the existing (and potentially conservative) $T_{L}$ processing criterion driving most JHCM glass formulations (e.g., $\mathrm{T}_{\mathrm{L}}<1050^{\circ} \mathrm{C}$ ). Goles et al. (2002) provide a summary of the JHCM demonstration using ICCM-13. 


\section{Glossary}

\begin{tabular}{|c|c|}
\hline $\mathrm{ADS}$ & Analytical Development Section \\
\hline ARM & Approved Reference Material (ARM-1) \\
\hline ASTM & American Society for Testing and Materials \\
\hline $\mathrm{CCC}$ & centerline canister cooling \\
\hline DOE & U.S. Department of Energy \\
\hline DWPF & Defense Waste Processing Facility \\
\hline EA & environmental assessment \\
\hline HLW & high-level waste \\
\hline ICCM & induction-heated, cold-crucible melter \\
\hline ICP-AES & inductively coupled plasma-atomic emission spectroscopy \\
\hline INEEL & Idaho National Environmental and Engineering Laboratory \\
\hline INTEC & Idaho Nuclear Technology and Engineering Center \\
\hline JHCM & Joule-heated, ceramic-lined melter \\
\hline KRI & V.G. Khlopin Radium Institute \\
\hline LAW & low-activity waste \\
\hline PCT & Product Consistency Test \\
\hline PNNL & Pacific Northwest National Laboratory \\
\hline RSM & research scaled melter \\
\hline SBW & sodium-bearing waste \\
\hline SEM-EDS & scanning electron microscopy-electron dispersive spectroscopy \\
\hline SIA & Scientific and Industrial Association \\
\hline SRS & Savannah River Site \\
\hline SRTC & Savannah River Technology Center \\
\hline $\mathrm{T}$ & temperature \\
\hline $\mathrm{T}_{\mathrm{L}}$ & liquidus temperature \\
\hline $\mathrm{T}_{\mathrm{M}}$ & melt temperature \\
\hline TRU & transuranic (waste) \\
\hline
\end{tabular}


Immobilization Technology Section

WSRC-TR-2002-00426

Savannah River Technology Center

Rev. 0

Westinghouse Savannah River Company

$\eta \quad$ viscosity

VSL Vitreous State Laboratory

WAPS Waste Acceptance Product Specification

WL waste loading

WSRC Westinghouse Savannah River Company

WVDP West Valley Demonstration Project

XRD X-ray diffraction 


\section{Contents}

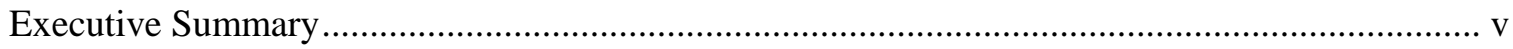

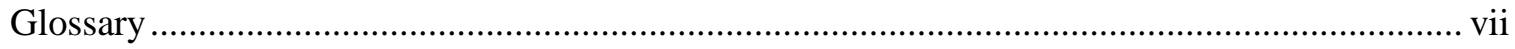

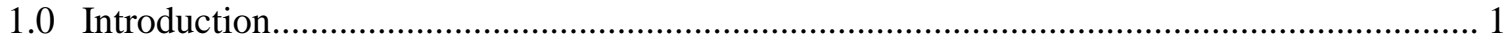

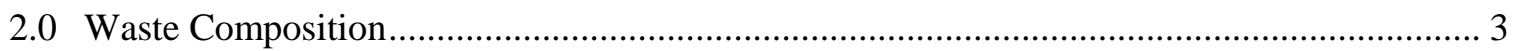

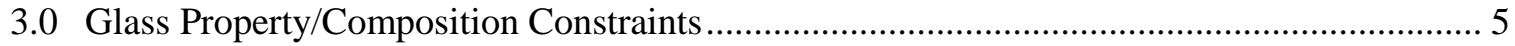

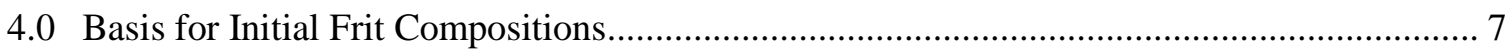

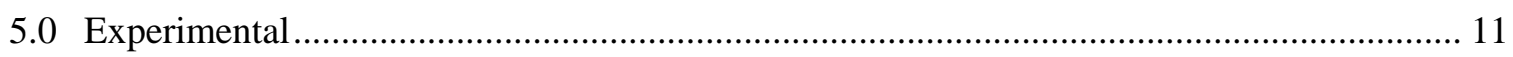

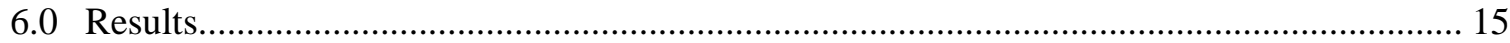

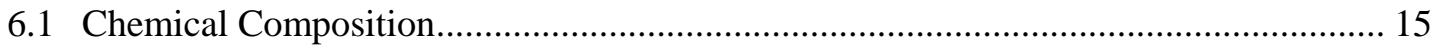

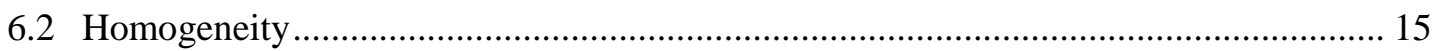

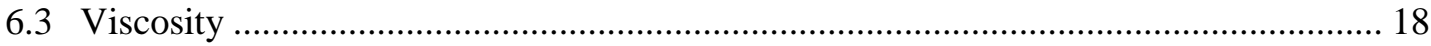

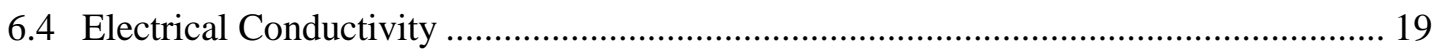

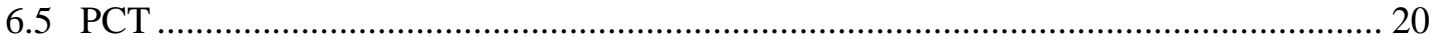

6.5.1 Effect of Crystallization on Durability …….................................................. 22

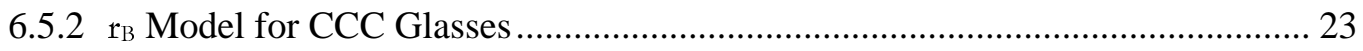

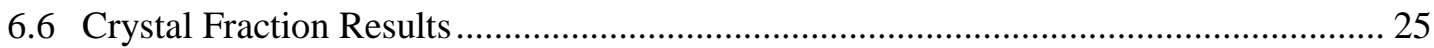

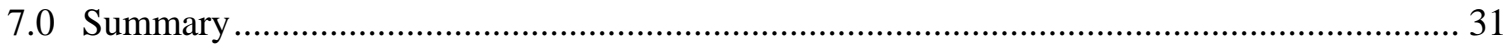

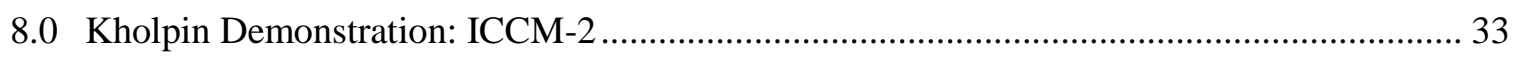

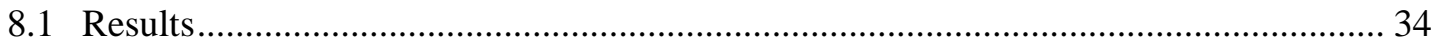

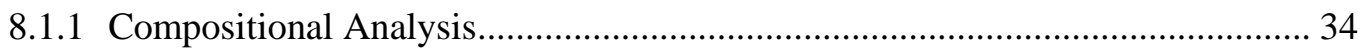

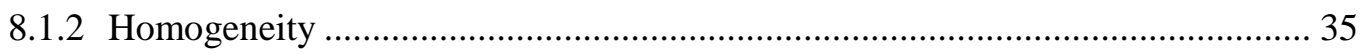

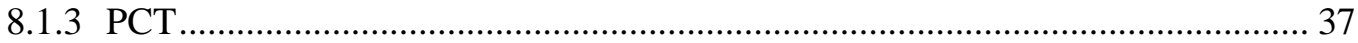

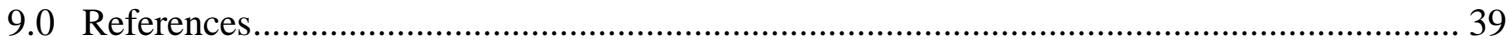

Appendix A Target Versus Measured Chemical Composition Data ......................................... 41

Appendix B XRD Results for ICCM Glasses as a Function of Heat Treatment ........................ 47

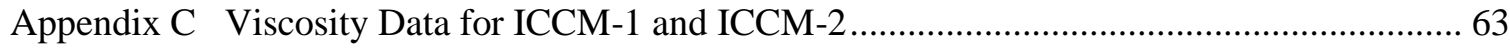


Immobilization Technology Section

WSRC-TR-2002-00426

Savannah River Technology Center

Rev. 0

Westinghouse Savannah River Company

This page intentionally left blank. 


\section{List of Figures}

Figure 4-1. Scatter Plot of ICCM-1 Through -10 Glass Composition Variables 9

Figure 6-1. Electrical Conductivity of ICCM-2 at 60\% WL Melt as a Function of Inverse Temperature

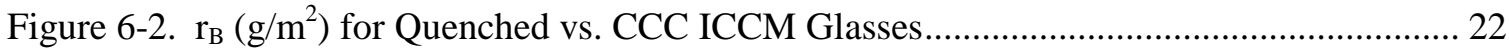

Figure 6-3. $\ln r_{B}$ from CCC Versus Quenched Glasses Within Hanford Composition Region (Kim et al. 1995)

Figure 6-4. Comparison of Measured and Predicted $\ln \left[\mathrm{r}_{\mathrm{B}}\right]$ from CCC ICCM Glasses 24

Figure 6-5. SEM Micrographs of Spinel in ICCM-2 Heat-treated Glass 27

Figure 6-6. Equilibrium Crystal Fraction in ICCM-2 as a Function of Temperature. 28

Figure 6-7. Comparison of Measured and Predicted $\mathrm{C}_{0,1050}$ Values in Mass\%. 29

Figure 8-1. Sample of ICCM-2 Glass Received from Kholpin (monolith was approximately half the diameter of the 155 -mm crucible) 34

Figure 8-2. XRD Pattern of ICCM-2 Interior. 36

Figure 8-3. XRD Pattern of ICCM-2 Exterior 36 
Immobilization Technology Section

WSRC-TR-2002-00426

Savannah River Technology Center

Rev. 0

Westinghouse Savannah River Company

This page intentionally left blank. 


\section{List of Tables}

Table 2-1. Composition Summary for C-106/AY-102 Waste Simulant...................................... 4

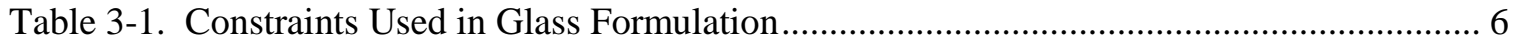

Table 4-1. Frit Compositions Tested in This Study .............................................................. 10

Table 5-1. Centerline Canister Cooling Schedule Utilized...................................................... 12

Table 6-1. Visual Observations of Homogeneity for Quenched ICCM Glasses ........................ 16

Table 6-2. Visual Observations of Homogeneity for CCC ICCM Glasses ................................ 17

Table 6-3. Measured $\eta_{1250^{\circ} \mathrm{C}}$ for the ICCM-1 and ICCM-2 Glasses .......................................... 18

Table 6-4. Electrical Conductivity Data for ICCM-2 (70 mass\% WL) Glass Melt ..................... 19

Table 6-5. Normalized PCT Results $\left(\mathrm{g} / \mathrm{m}^{2}\right)$ for Quenched and CCC ICCM Glasses ................... 21

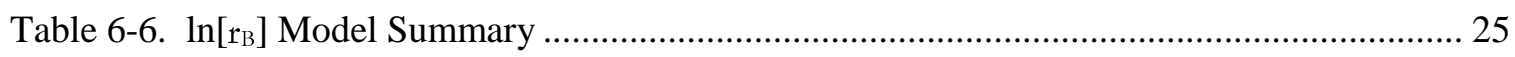

Table 6-7. Crystal Fraction in ICCM Test Glasses (in mass\%) ............................................... 25

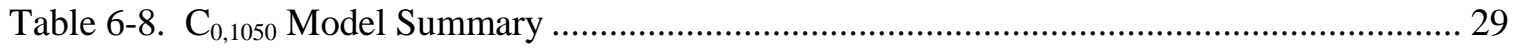

Table 8-1. Chemical Composition of the Glass Produced in Khlopin Testing (mass\%)............. 35

Table 8-2. Average Measured PCT Normalized Release (g/L) ............................................... 37 
Immobilization Technology Section

WSRC-TR-2002-00426

Savannah River Technology Center

Rev. 0

Westinghouse Savannah River Company

This page intentionally left blank. 


\subsection{Introduction}

Waste streams at the U.S. Department of Energy's (DOE's) Hanford and Savannah River sites contain a varied array of chemical compounds, a number of which can limit the waste loading or cause operating difficulties with melt rate or equipment corrosion. The vitrification programs at Hanford and Savannah River may benefit from higher temperature glass formulations that are processable in advanced melters. In many cases, higher melt temperatures permit higher waste loadings in the glass given solubility limits of refractory components, such as aluminum, zirconium, and chromium, can be increased. A higher tolerance for solid phases in the melter (e.g., processing with a minimal volume fraction of solid phases) would also permit higher loadings of many high-level wastes (HLW) in glass (Perez et al. 2001).

However, prior to implementation or routine use of advanced melters in DOE radioactive waste treatment facilities, some technical issues need to be addressed. Some of the issues include:

- Life of melter materials;

- Ability to accommodate electrically conductive noble metal fission products;

- Power requirements and control stability (with slurry feeding and secondary phases);

- Ability to meet production rate goals with liquid feed (melt rate);

- Ability to increase waste loading; and

- Offgas emissions treatment.

It has been proposed that the induction-heated, cold-crucible melter (ICCM) technology, because of the formation of a cold glass layer at the glass/crucible interface, may be able to achieve these higher temperatures while also being less susceptible to corrosion by high halide and sulfate feeds than current HLW melters. It has also been proposed that this melter technology is more resistant to electrical shorting due to noble metals because electrodes are not used and strong convection currents are invoked in the melter. This technology may also provide a higher tolerance for solid phases in the melt without adversely affecting processing. If proven or shown to be effective, this could potentially open up the operating window to assess higher waste loaded systems. Other possible advantages directly related to the ICCM include a smaller footprint size, possibly lower design and fabrication costs, and an increase in melter life and reduction in cost for disposal. Some designs of the cold crucible melters may also incorporate mechanical stirring devices potentially leading to increased throughput. Melter simplicity and smaller, yet potentially higher-throughput, equipment provide the opportunity to reduce the life-cycle cost and simplify final melter disposal.

The DOE and the Russian Ministry of Atomic Energy are collaborating to investigate high temperature induction heated cold crucible melters for application to DOE wastes. Determination of the benefit and applicability of this type of technology to U.S. waste streams was initiated in fiscal year 2001 with limited testing performed on Idaho National Engineering and Environmental Laboratory (INEEL) sodiumbearing waste (SBW) surrogate (Herman 2002a; Herman 2002b). Cooperative tests with the V.G. Khlopin Radium Institute (KRI) and the Scientific and Industrial Association (SIA) Radon Facility are being performed to determine the incentive and applicability of the ICCM technology to DOE high level waste streams (Herman et al. 2002a; Herman et al. 2002b). The key goals of this program are to obtain enough information on this technology with DOE wastes to estimate design modification requirements, production capacities, product quality, melter life, and associated costs to determine if full-scale testing is desirable and necessary. This program will provide the general information to permit the individual sites to perform more detailed cost/benefit analyses for implementation. 
The initial tests were held at KRI in the spring of fiscal year 2002 with a DOE surrogate high-alkaline waste. The non-radioactive surrogate is based on a specific Hanford waste stream but will also provide valuable information to the Savannah River Site (SRS) - given the relatively high concentrations of $\mathrm{Fe}_{2} \mathrm{O}_{3}, \mathrm{Cr}_{2} \mathrm{O}_{3}$, and $\mathrm{Al}_{2} \mathrm{O}_{3}$ and the cross-cutting assessment of the Strontium/TRU precipitation or permanganate-based pretreatment process being considered at both sites. It should be noted that the glass formulation efforts to support the advanced melter task may not provide optimum processing or product performance properties but are solely scoping in nature to assure the incentives for this technology are met or defined. Major incentives include:

1. Demonstrate the ability to run slurry feed in an ICCM.

2. Demonstrate that the melter system can produce an acceptable glass in terms of product quality as dictated by the Waste Acceptance Product Specifications (WAPS) (DOE 1996).

3. Demonstrate the potential for processing high waste loading glasses $(\geq 60 \%$ on a calcined, oxide basis).

It has also been proposed (Hrma et al. 2002) that standard Joule-heated ceramic-melters (JHCM) may be able to operate effectively with greater crystal solid fraction than is currently allowed. Hrma et al. (2002) have shown that the major factor controlling sludge accumulation within the melter is crystal size rather than liquidus temperature $\left(\mathrm{T}_{\mathrm{L}}\right)$. The first step toward demonstrating the feasibility of changing the current $\mathrm{T}_{\mathrm{L}}$-based limit for JHCMs is to operate scaled melters and characterize the fate and distribution of crystals formed.

The focus of this report is on the glass formulation activities in support of the ICCM and JHCM demonstrations with the high-alkaline waste stream. Again, the intent is to provide preliminary (nonoptimized) glass formulations for a specific waste stream that met processing requirements, DOE product quality specifications, and programmatic objectives for the two melter types.

In Section 2.0, the waste composition selected for this study is presented. In Section 3.0, glass property/composition constraints used to guide glass formulation efforts are established. The basis for initial frit development activities is discussed in Section 4.0. Details of the glass fabrication and characterization are discussed in Section 5.0. Section 6.0 summarizes the results with emphasis placed on two key areas: (1) the impact of devitrification on product quality and (2) the preliminary model development to predict the crystalline volume fraction as a function of temperature and composition. Section 7.0 summarizes this work scope and provides recommendations for subsequent JHCM and ICCM demonstrations. Section 8.0 provides a brief description and characterization of glass produced during initial tests at KRI using the ICCM technology. 


\subsection{Waste Composition}

The Hanford C-106/AY-102 High Level Waste simulant was selected as the waste stream to be tested to represent the DOE high-alkaline surrogate. This surrogate represents a blend of tanks that will be processed during initial HLW vitrification efforts at Hanford. Iron and aluminum are the predominant cations in the simulant - thus making it directly applicable to SRS wastes. The projected composition also accounts for sludge washing that will be performed as part of the Hanford HLW pretreatment process as well as recycle products from the waste pretreatment processes as currently defined. The major pretreatment contributors are $\mathrm{MnO}$ and $\mathrm{SrO}$. Inclusion of the recycle products $\mathrm{MnO}$ and $\mathrm{SrO}$ are also directly applicable to SRS given the current assessment of the permanganate-based pretreatment process (Duff et al. 2002).

Table 2-1 presents the waste simulant composition (with pretreatment products) as provided by the Vitreous State Laboratory at The Catholic University of America (VSL-00R2520-1, "Physical and Rheological Properties of Waste Simulants and Melter Feeds for RPP-WTP HLW Vitrification"). This simulant has been the focus of recent glass formulation activities in support of JHCM testing and will thus allow some comparisons to be made between melter technologies. 
Table 2-1. Composition Summary for C-106/AY-102 Waste Simulant

\begin{tabular}{|c|c|}
\hline & $\begin{array}{l}\text { C-106/AY-102 } \\
\text { Sludge + } \\
\text { Pretreatment } \\
\text { Products }\end{array}$ \\
\hline $\mathrm{Ag}_{2} \mathrm{O}$ & $0.46 \%$ \\
\hline $\mathrm{Al}_{2} \mathrm{O}_{3}$ & $20.91 \%$ \\
\hline $\mathrm{BaO}$ & $0.13 \%$ \\
\hline $\mathrm{CaO}$ & $1.39 \%$ \\
\hline $\mathrm{CdO}$ & $0.09 \%$ \\
\hline $\mathrm{CeO}_{2}$ & $0.06 \%$ \\
\hline $\mathrm{Cl}$ & $0.05 \%$ \\
\hline $\mathrm{Cr}_{2} \mathrm{O}_{3}$ & $0.32 \%$ \\
\hline $\mathrm{Cs}_{2} \mathrm{O}$ & $0.20 \%$ \\
\hline $\mathrm{F}$ & $0.05 \%$ \\
\hline $\mathrm{Fe}_{2} \mathrm{O}_{3}$ & $22.76 \%$ \\
\hline $\mathrm{K}_{2} \mathrm{O}$ & $0.05 \%$ \\
\hline $\mathrm{La}_{2} \mathrm{O}_{3}$ & $0.22 \%$ \\
\hline $\mathrm{MgO}$ & $0.43 \%$ \\
\hline $\mathrm{MnO}$ & $8.61 \%$ \\
\hline $\mathrm{Na}_{2} \mathrm{O}$ & $16.23 \%$ \\
\hline $\mathrm{NiO}$ & $0.30 \%$ \\
\hline $\mathrm{P}_{2} \mathrm{O}_{5}$ & $0.29 \%$ \\
\hline $\mathrm{PbO}$ & $0.42 \%$ \\
\hline $\mathrm{PdO}$ & $0.01 \%$ \\
\hline $\mathrm{Rh}_{2} \mathrm{O}_{3}$ & $0.01 \%$ \\
\hline $\mathrm{RuO}_{2}$ & $0.02 \%$ \\
\hline $\mathrm{SO}_{3}$ & $0.05 \%$ \\
\hline $\mathrm{SiO}_{2}$ & $11.43 \%$ \\
\hline $\mathrm{SrO}$ & $14.26 \%$ \\
\hline $\mathrm{TiO}_{2}$ & $0.08 \%$ \\
\hline $\mathrm{UO}_{2}$ & $1.01 \%$ \\
\hline $\mathrm{ZrO}_{2}$ & $0.23 \%$ \\
\hline TOTAL & $100 \%$ \\
\hline
\end{tabular}




\subsection{Glass Property/Composition Constraints}

With the goal of developing an acceptable glass to demonstrate relatively high waste loadings for HLW waste streams, a definition of an acceptable glass must first be established. Two types of glass-property limitations must be considered: 1) those product properties required for waste-form acceptance and 2) those processing properties required for adequate melter operation. The product-property requirements for acceptance in the federal repository are dictated by the WAPS (DOE 1996). The WAPS imposes limitations on the response of glass to the product consistency test (PCT) (ASTM 1998) and requires that chemical and phase-stability information be reported. The specific limit set on the PCT response is that the releases of boron, sodium, and lithium, normalized to glass composition, must be significantly less than those of the Defense Waste Processing Facility (DWPF) Environmental Assessment (EA) glass. The normalized releases of boron $\left(\mathrm{r}_{\mathrm{B}}\right)$, sodium $\left(\mathrm{r}_{\mathrm{Na}}\right)$, and lithium $\left(\mathrm{r}_{\mathrm{Li}}\right)$ for the DWPF-EA glass are $8.35 \mathrm{~g} / \mathrm{m}^{2}$, $6.67 \mathrm{~g} / \mathrm{m}^{2}$, and $4.78 \mathrm{~g} / \mathrm{m}^{2}$, respectively (Jantzen et al. 1993). ${ }^{2}$ For the purposes of this study, we used a conservative (with respect to EA) upper release limit of $2 \mathrm{~g} / \mathrm{m}^{2}$ for $\mathrm{r}_{\mathrm{B}}, \mathrm{r}_{\mathrm{Na}}$, and $\mathrm{r}_{\mathrm{Li}}$ for acceptability to guide glass formulation efforts. Although a conservative normalized release limit was used, glasses exceeding this limit were tested to gain insight into potential compositional adjustments that would minimize crystal formation with potential adverse impacts on both processability and product quality. It should also be noted that acceptability should not be based on this conservative limit but solely on DOE established criteria.

An additional product property related restriction considered in this study relates to the formation of secondary phases during cooling, which may detract from the durability of glass. Specifically, glasses formed from wastes high in $\mathrm{Na}$ and $\mathrm{Al}$ are susceptible to nepheline crystallization during cooling, which has been shown to increase the normalized PCT releases of some glasses ( $\mathrm{Li}$ et al. 1997; Li et al. 1998). $\mathrm{Li}$ et al. (1997) showed that glasses with $\mathrm{Na}_{2} \mathrm{O} \cdot \mathrm{Al}_{2} \mathrm{O}_{3} \cdot \mathrm{SiO}_{2}$ sub-mixtures within the nepheline primary phase field in that ternary mixture are susceptible to nepheline formation. For practical purposes, glasses with $\left[\mathrm{SiO}_{2}\right] /\left(\left[\mathrm{Na}_{2} \mathrm{O}\right]+\left[\mathrm{Al}_{2} \mathrm{O}_{3}\right]+\left[\mathrm{SiO}_{2}\right]\right) \geq 0.62$ are less susceptible to nepheline formation. In this study, the formation of nepheline on a simulated canister centerline cooling (CCC) schedule did not eliminate a particular glass from further consideration. However, the durability of the resulting multiphase borosilicate glass (using bounding thermal histories) was required to meet the standard for acceptability set forth by the WAPS.

The processing related properties used in development of the glass formulations include those assumed to be pertinent to processing in either the ICCM or the JHCM depending upon the purpose. The waste vitrification experiences in France and Russia were guides for processing constraints for the ICCM. For this melter technology, a nominal melter operating temperature limit was not considered given the glass contact material is not (or at least is less) susceptible to corrosion. However, at high temperatures the volatility from the glass melt can be excessive for high alkali waste glasses and at excessively low temperatures the feed-to-glass process rates are low. Based on the process temperatures used in waste immobilization by ICCM, the acceptable processing range is considered to be between 1100 and $1400^{\circ} \mathrm{C}$ and a determination will be made if this criterion is restrictive. The process viscosity can be easily adjusted through temperature by altering the melter power input. The nominal operating viscosity was assumed to be between 2 and $10 \mathrm{~Pa} \cdot \mathrm{s}$. The electrical conductivity of glass was restricted to between 10 and $100 \mathrm{~S} / \mathrm{m}$ at the nominal melter operating temperature and a frequency $>1 \mathrm{kHz}{ }^{3}$ With a bottom drain configuration, operated in semi-batch mode, the ICCM is expected to tolerate a larger fraction of solid

\footnotetext{
${ }^{2}$ To convert $\mathrm{g} / \mathrm{m}^{2}$ to $\mathrm{g} / \mathrm{L}$ multiply by 2 for a $2000 \mathrm{~m}^{-1}$ surface-area to volume ratio based test.

${ }^{3}$ The electrical conductivity is assumed to be independent of frequency at frequencies $\geq 1 \mathrm{kHz}$.
} 
phase than permitted by the standard DWPF or West Valley Demonstration Project (WVDP) designed JHCMs. Therefore, in place of a liquidus temperature $\left(\mathrm{T}_{\mathrm{L}}\right)$ restriction, the volume fraction of crystalline phase in equilibrium with the melt (at $\mathrm{T}_{\mathrm{M}}$ ) will be restricted to $\leq 3 \mathrm{vol} . \%$. No specific constraints on the power absorption or the skull stability related properties were used. Table 3-1 summarizes the glass property and composition constraints used to develop a glass to demonstrate the processability of relatively high waste loaded glasses.

To determine the processing property requirements for the JHCM, the DWPF and WVDP melter requirements with the exception of the $T_{L}$ constraint were used. Instead of the $T_{L}$ constraint, an upper limit of $3 \mathrm{vol} . \%$ was imposed on solid phases present at $1050^{\circ} \mathrm{C}$ in the melt at equilibrium. These constraints are listed in Table 3-1 As previously mentioned, although these constraints define the criteria for glass acceptability, glasses outside these constraints were included in the development efforts to better understand the effects of compositional variation on specific glass properties of interest. As will be discussed in more detail in Section 4.0, of particular interest was the glass formulation strategy taken to balance the volume percent crystallization issues encountered with the potential formation of nepheline and its ultimate impact on product quality.

Table 3-1. Constraints Used in Glass Formulation

\begin{tabular}{||c|c|c|}
\hline Property & ICCM & JHCM \\
\hline Nominal operating temperature $\left(\mathrm{T}_{\mathrm{M}}\right)$ & $1100 \leq \mathrm{T}_{\mathrm{M}} \leq 1400$ & $\mathrm{~T}_{\mathrm{M}} \leq 1150^{\circ} \mathrm{C}$ \\
\hline Viscosity at $\mathrm{T}_{\mathrm{M}}\left(\eta_{\mathrm{M}}\right)$ & $2<\eta_{\mathrm{M}}<10 \mathrm{~Pa} \cdot \mathrm{s}$ & $2<\eta_{\mathrm{M}}<10 \mathrm{~Pa} \cdot \mathrm{s}$ \\
\hline Electrical conductivity at $\mathrm{T}_{\mathrm{M}}\left(\varepsilon_{\mathrm{M}}\right)$ & $10<\varepsilon_{\mathrm{M}}<100 \mathrm{~S} / \mathrm{m}$ & $10<\varepsilon_{\mathrm{M}}<100 \mathrm{~S} / \mathrm{m}$ \\
\hline Liquidus temperature $\left(\mathrm{T}_{\mathrm{L}}\right)$ & -- & -- \\
\hline $\begin{array}{c}\text { Normalized PCT boron release }\left(\mathrm{r}_{\mathrm{B}}\right) \text { (both } \\
\text { quenched and CCC samples) }\end{array}$ & $\mathrm{r}_{\mathrm{B}}<2 \mathrm{~g} / \mathrm{m}^{2}$ & $\mathrm{r}_{\mathrm{B}}<2 \mathrm{~g} / \mathrm{m}^{2}$ \\
\hline $\begin{array}{c}\text { Normalized PCT sodium release }\left(\mathrm{r}_{\mathrm{Na}}\right) \text { (both } \\
\text { quenched and CCC samples) }\end{array}$ & $\mathrm{r}_{\mathrm{Na}}<2 \mathrm{~g} / \mathrm{m}^{2}$ & $\mathrm{r}_{\mathrm{Na}}<2 \mathrm{~g} / \mathrm{m}^{2}$ \\
\hline $\begin{array}{c}\text { Normalized PCT lithium release }\left(\mathrm{r}_{\mathrm{Li}}\right) \text { (both } \\
\text { quenched and CCC samples) }\end{array}$ & $\mathrm{r}_{\mathrm{Li}}<2 \mathrm{~g} / \mathrm{m}^{2}$ & $\mathrm{r}_{\mathrm{Li}}<2 \mathrm{~g} / \mathrm{m}^{2}$ \\
\hline Crystalline Volume Percent at $\mathrm{T}_{\mathrm{M}}$ & $\leq 3 \mathrm{vol} . \%$ & $\leq 3 \mathrm{vol} . \%$ \\
\hline
\end{tabular}




\subsection{Basis for Initial Frit Compositions}

For the glasses formulated in this study, the main obstacle for obtaining high WLs (e.g., $\geq 60$ mass\%) was a balance between the crystal fraction and the CCC PCT release constraints. More specifically, the high concentrations of $\mathrm{MnO}$ and $\mathrm{Fe}_{2} \mathrm{O}_{3}, 8.61$ and 22.76 mass\%, respectively, promote the formation of high concentrations of spinel in the glass melt. While the high concentrations of $\mathrm{Na}_{2} \mathrm{O}$ and $\mathrm{Al}_{2} \mathrm{O}_{3}, 16.23$ and 20.91 mass \%, respectively, promote the formation of nepheline on CCC, which can increase PCT releases in some glasses - depending upon volume percent and the impact on the residual glass composition. High waste loading in a JHCM for this particular waste stream can only be achieved by balancing the glass composition so that the crystal content in the melt is minimized (e.g., increasing $\mathrm{Na}_{2} \mathrm{O}$ and other alkali) while minimizing the PCT release from CCC glass (e.g., reducing $\mathrm{Na}_{2} \mathrm{O}$ and other alkali).

Therefore, to challenge the existing (and potentially conservative) $\mathrm{T}_{\mathrm{L}}$ processing criterion driving most JHCM glass formulations, a balance between an acceptable (yet undefined) crystalline volume fraction and the PCT response must be met. The ICCM, as we will discuss later, has the potential to achieve a higher waste loading even with the same product quality and crystallinity constraints by increasing $\mathrm{T}_{\mathrm{M}}$. At a fixed $\mathrm{T}_{\mathrm{M}}$, the potential for higher waste loadings is also a function of the melter's ability to tolerate a higher crystalline volume fraction. It is anticipated that the ICCM will tolerate higher crystal fractions than current JHCM designs.

To develop glasses with the appropriate processing and product quality related properties, glass property composition models were used. These models include: Arrhenius viscosity model (Vienna et al. 2002), Arrhenius electrical conductivity model (Hrma et al. 1994), logarithm PCT release models for quenched glasses (Vienna et al. 2002), nepheline formation estimate (Li et al. 1998), and spinel volume fraction estimate (Hrma and Vienna 2003). It should be noted that the glasses fabricated were outside of the valid composition region for all property models used. Therefore, these property models were only useful as rough indicators of properties and could not be relied upon for accurate property prediction.

A number of frits were developed for specific loadings of the C106/AY102 simulant (with pretreatment products) and target $\mathrm{T}_{\mathrm{M}}$ values. The compositions of these frits are given in Table 4-1. Although the glasses were designed for different melter technologies, the nomenclature used is ICCM-XX to associate them with the same study.

The first glass developed (ICCM-1) was targeted to have a viscosity of $7.5 \mathrm{~Pa} \cdot \mathrm{s}$ at $1200^{\circ} \mathrm{C}$, with a normalized silica concentration $\left(\mathrm{N}_{\mathrm{Si}}=\left[\mathrm{SiO}_{2}\right] /\left(\left[\mathrm{SiO}_{2}\right]+\left[\mathrm{Al}_{2} \mathrm{O}_{3}\right]+\left[\mathrm{Na}_{2} \mathrm{O}\right]\right)\right)$ of 62 mass\% to minimize the potential formation of nepheline during CCC. ${ }^{4}$ ICCM-1 contained 60 mass $\%$ of the simulated waste and met the property criteria set forth in Table 3-1. To take advantage of the higher temperature melting capabilities of the ICCM, ICCM-2 was formulated with 70\% WL and an estimated viscosity of $5 \mathrm{~Pa} \cdot \mathrm{s}$ at $1350^{\circ} \mathrm{C}$. This glass had a $\mathrm{N}_{\mathrm{Si}}$ of only $56.5 \%$ which would indicate that nepheline formation on cooling was expected. The residual glass composition was estimated assuming that the nepheline formed was stoichiometric $\left(\mathrm{NaAlSiO}_{4}\right)$ and that nepheline continued to form until at least one of the constituents was exhausted from the melt. This residual glass composition, although outside the range of model validity, was estimated by the PCT models to have adequate release. ICCM-2 was the target composition for the initial ICCM test described by Herman et al. (2002a and 2002b). Section 8.0 summarizes the limited characterization efforts of the ICCM-2 glass resulting from preliminary KRI tests.

\footnotetext{
${ }^{4}$ Note that the predicted $\mathrm{N}_{\mathrm{Si}}$ of 0.62 lies directly on the discriminatory line for nepheline formation ignoring uncertainties associated with the application of this submixture model to this compositional space.
} 
After the development of ICCM-2, formulation efforts shifted to developing glasses to support the JHCM demonstration. ICCM-3 through -13 were designed to melt at $1150^{\circ} \mathrm{C}$, with varying waste loading, $\mathrm{N}_{\mathrm{Si}}$, and composition. Based on the property-composition models, these glasses were expected to have adequate quenched glass PCT release, viscosity, and electrical conductivity. The focus of these ten melts was to minimize equilibrium crystal volume fraction of the melt while obtaining adequate CCC glass PCT releases - the balanced approach previously discussed. The equilibrium crystal volume fraction model (Hrma and Vienna 2003), developed over a distinctly different glass composition region, was found to poorly predict the measured crystal fractions of ICCM-1 through -13. It is assumed that this poor prediction is due to the high concentrations of $\mathrm{SrO}$ and $\mathrm{MnO}$ in these glasses. To better estimate the crystal volume fraction at $1050^{\circ} \mathrm{C}$ and the PCT response of CCC glasses, ICCM-1 through ICCM-10 were fabricated and tested with systematic variation in frit component concentrations (while maintaining adequate predicted responses to those properties which could be estimated by models - viscosity, electrical conductivity, and quenched glass PCT release). Section 5.0 provides a detailed discussion of the fabrication and testing of the ICCM glasses. Figure 4-1 shows a scatter plot matrix of the components varied in ICCM-1 through ICCM-10. A relatively good coverage of the composition region was obtained despite the constraints on other glass properties. This data set was used to develop $1^{\text {st }}$ order empirical models for equilibrium crystal volume fraction of crystals at $1050^{\circ} \mathrm{C}$ and $\ln \left[\mathrm{r}_{\mathrm{B}}\right]$ from CCC glass. The models, discussed in Section 6.0 were used to develop glasses ICCM-11 through -13. ICCM-13 was chosen for testing in the JHCM (Goles et al. 2002).

The initial testing with the ICCM-2 composition in a small scale ICCM (based on a batch process - not continuous slurry fed) indicated potential processing difficulties. ${ }^{5}$ Circumstantial evidence from the test suggested that temperatures near the bottom of the melter were as low as $1100^{\circ} \mathrm{C}$, which caused crystallization of spinel and nepheline in relatively large concentrations. Section 8.0 provides more details on the glass resulting from the initial tests at KRI. It was determined that a new formulation may be required with a lower propensity for nepheline formation and, more importantly, a lower viscosity and lower slope of the logarithm viscosity versus inverse temperature relationship (increased length or decreased sensitivity of viscosity to temperature). The lower viscosity and increased glass length is expected to help maintain more uniform temperature in the small scale ICCM being used for testing. ICCM-14 was developed to meet these requirements while maintaining a waste loading of 70 mass\% and adequate processing and product quality properties. This glass was designed to have a viscosity of 3.7 $\mathrm{Pa} \cdot \mathrm{s}$ at $1300^{\circ} \mathrm{C}$. An additional frit, Aloy-3, was developed by researchers at KRI as a candidate for use in follow-on tests. Its composition and properties are similar to those of ICCM-14.

\footnotetext{
${ }^{5}$ C.C. Herman, Meeting Minutes for Planning Meeting with Khlopin for High Alkaline Waste Testing, SRT-GPD2002-00107, August 13, 2002.
} 


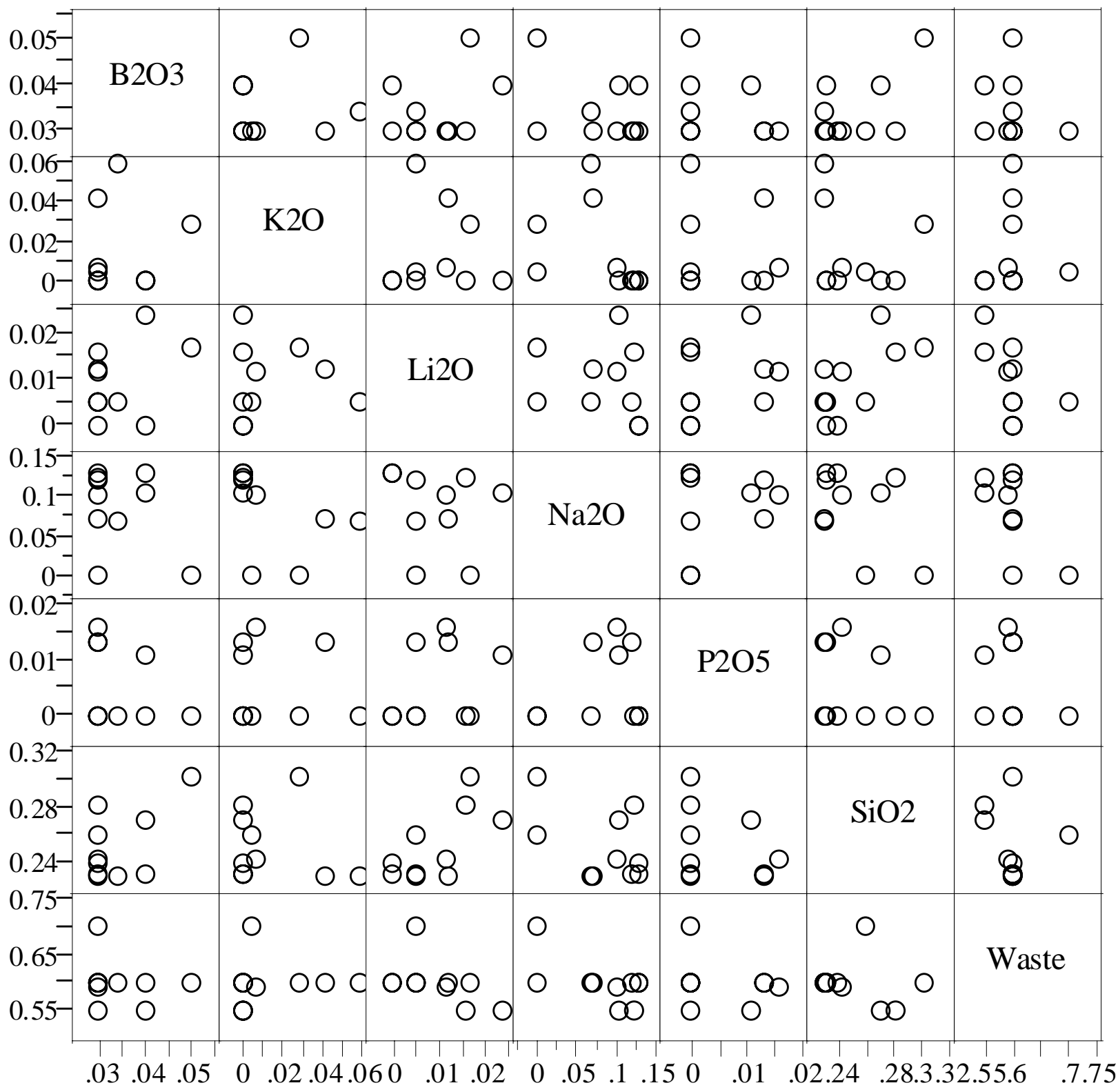

Figure 4-1. Scatter Plot of ICCM-1 Through -10 Glass Composition Variables 
Table 4-1. Frit Compositions Tested in This Study

\begin{tabular}{|c|c|c|c|c|c|c|c|c|}
\hline Frit & ICCM-1 & ICCM-2 & ICCM-3 & ICCM-4 & ICCM-5 & ICCM-6 & ICCM-7 & ICCM-8 \\
\hline $\mathrm{B}_{2} \mathrm{O}_{3}$ & 12.500 & 10.000 & 8.537 & 7.500 & 7.317 & 8.889 & 7.500 & 6.667 \\
\hline $\mathrm{K}_{2} \mathrm{O}$ & 7.323 & 1.550 & 14.925 & 10.614 & 1.742 & 0.000 & 0.000 & 0.000 \\
\hline $\mathrm{Li}_{2} \mathrm{O}$ & 4.243 & 1.667 & 1.264 & 2.998 & 2.839 & 5.250 & 1.250 & 3.497 \\
\hline $\mathrm{Na}_{2} \mathrm{O}$ & 0.524 & 0.000 & 17.594 & 17.907 & 24.987 & 23.295 & 30.000 & 27.270 \\
\hline $\mathrm{P}_{2} \mathrm{O}_{5}$ & 0.000 & 0.000 & 0.000 & 3.300 & 3.837 & 2.411 & 3.300 & 0.000 \\
\hline $\mathrm{SiO}_{2}$ & 75.410 & 86.783 & 57.680 & 57.680 & 59.279 & 60.155 & 57.950 & 62.566 \\
\hline Sum & 100.000 & 100.000 & 100.000 & 100.000 & 100.000 & 100.000 & 100.000 & 100.000 \\
\hline Target WL & $60 \%$ & $70 \%$ & $60 \%$ & $60 \%$ & ב59\% & ב55\% & $60 \%$ & ב55\% \\
\hline $\begin{array}{l}\text { Target } \\
\text { Melter }\end{array}$ & ICCM & ICCM & $\mathrm{JHCM}$ & JHCM & $\mathrm{JHCM}$ & $\mathrm{JHCM}$ & $\mathrm{JHCM}$ & JHCM \\
\hline Frit & ICCM-9 & ICCM-10 & ICCM-11 & ICCM-12 & ICCM-13 & ICCM-14 & Aloy-3 & \\
\hline $\mathrm{B}_{2} \mathrm{O}_{3}$ & 7.500 & 10.000 & 17.262 & 15.000 & 30.200 & 8.33 & 13.33 & \\
\hline $\mathrm{K}_{2} \mathrm{O}$ & 0.000 & 0.000 & 13.055 & 14.925 & 0.000 & 0.00 & 0.00 & \\
\hline $\mathrm{Li}_{2} \mathrm{O}$ & 0.000 & 0.000 & 2.586 & 1.333 & 2.702 & 6.66 & 6.67 & \\
\hline $\mathrm{Na}_{2} \mathrm{O}$ & 32.532 & 32.067 & 0.000 & 3.505 & 0.000 & 0.00 & 0.00 & \\
\hline $\mathrm{P}_{2} \mathrm{O}_{5}$ & 0.000 & 0.000 & 0.000 & 0.000 & 0.000 & 0.00 & 0.00 & \\
\hline $\mathrm{SiO}_{2}$ & 59.968 & 57.933 & 67.097 & 65.238 & 67.097 & 85.01 & 80.00 & \\
\hline Sum & 100.000 & 100.000 & 100.000 & 100.000 & 100.000 & 100.000 & 100.000 & \\
\hline Target WL & $60 \%$ & $60 \%$ & $60 \%$ & $60 \%$ & $60 \%$ & $70 \%$ & $70 \%$ & \\
\hline $\begin{array}{l}\text { Target } \\
\text { Melter }\end{array}$ & JHCM & JHCM & JHCM & JHCM & JHCM & ICCM & ICCM & \\
\hline
\end{tabular}




\subsection{Experimental}

A series of crucible tests was performed using reagent-grade oxides, carbonates, and boric acid prior to recommending a frit composition in support of melter demonstrations. Glasses produced in this series were based on the C-106/AY-102 simulant composition with pretreatment products (see Table 2-1) coupled with the candidate frit compositions (see Table 4-1) at specific waste loadings of interest. This section discusses the experimental procedures and characterization techniques used to assess various glass formulations against the pre-defined acceptance criteria (see Table 3-1).

Each batch was prepared from the proper proportions of reagent-grade metal oxides, carbonates, $\mathrm{H}_{3} \mathrm{BO}_{3}$, and salts in 150-g batches using standard batching and melting procedures. Batch sheets were filled out as the materials were weighed. Once batched, the glasses were melted using a standard thermal heat treatment. In general, the raw materials were thoroughly mixed and placed into a 95\% Platinum / 5\% Gold $250 \mathrm{~mL}$ crucible. The batch was subsequently placed into a high temperature furnace and the temperature was increased at $\sim 8^{\circ} \mathrm{C} /$ minute until the target melt temperature $\left(\mathrm{T}_{\mathrm{M}}\right)$ was reached. After an isothermal hold at $\mathrm{T}_{\mathrm{M}}$ for $1.0 \mathrm{~h}$, the crucible was removed and the glass was poured onto a clean stainless steel plate and allowed to air cool. Visual observations on the resulting pour patty and residual crucible glass were documented.

The pour patty and residual crucible glass were ground and the crushed glass was subsequently transferred to its original crucible for a second melt at $\mathrm{T}_{\mathrm{M}}$. After an isothermal hold at $\mathrm{T}_{\mathrm{M}}$ for $1.0 \mathrm{~h}$, the crucible was removed and the glass was poured onto a clean stainless steel plate and allowed to air cool. Visual observations on the resulting pour patty and residual crucible glass were documented. Approximately 140 grams of glass were removed (poured) from the crucible while $\sim 10$ grams remained in the crucible along the walls. The pour patty was used as a sampling stock for the various heat treatments and property measurements (e.g., chemical composition, homogeneity, crystalline volume fraction, viscosity and/or durability).

Although it was recognized that the sole use of laboratory-scale tests to predict performance of actual melter processing adds risk, the use of laboratory scale tests has been effective in the past to down select frit candidates for potential recommendation. The crucible-scale tests provide an effective method of evaluating candidate frits as well as assessing the properties constraining formulation efforts.

To bound the effects of thermal history on product performance, approximately 25 grams of each glass were heat treated to simulate cooling along the centerline of a DWPF-type canister (Marra and Jantzen 1993). This cooling regime, commonly referred to as the canister centerline cooling (CCC) curve, is described Table 5-1. This terminology will be utilized in this report to differentiate samples from the two cooling regimes (quenched versus CCC). 
Table 5-1. Centerline Canister Cooling Schedule Utilized

\begin{tabular}{||c|c|c|c||}
\hline \hline Step & $\begin{array}{c}\text { Ramp } \\
\left({ }^{\circ} \mathrm{C} / \mathrm{min}\right)\end{array}$ & $\begin{array}{c}\text { Target } \\
\text { Temperature }\left({ }^{\circ} \mathrm{C}\right)\end{array}$ & $\begin{array}{c}\text { Dwell } \\
(\mathrm{hr})\end{array}$ \\
\hline 1 & 10 & 1150 & 4 \\
\hline 2 & 8 & 926 & 0.1 \\
\hline 3 & 1 & 779 & 2.8 \\
\hline 4 & 1 & 715 & 3.4 \\
\hline 5 & 1 & 598 & 4.2 \\
\hline 6 & 1 & 490 & 4.3 \\
\hline 7 & 1 & 382 & 7.4 \\
\hline 8 & 1 & 70 & End \\
\hline
\end{tabular}

To confirm that the as-fabricated or quenched glasses corresponded to the defined target compositions, a representative sample from each glass pour patty was submitted for chemical analysis. Concentrations (as mass \%) for the cations of interest were measured by Inductively Coupled Plasma - Atomic Emission Spectroscopy (ICP - AES). To assess the performance of the ICP over the course of these analyses, glass standards were intermittently run.

Homogeneity was evaluated and documented for each ICCM glass. Homogeneity in this context refers to the presence of crystallization, not the presence of glass-in-glass phase separation (amorphous phase separation). Two methods were used to assess homogeneity: (1) X-ray diffraction (XRD) for all quenched and CCC glasses and (2) determination of the volume fraction crystallization for select ICCM glasses.

For the first assessment, representative samples for all "as-fabricated" (or quenched) and CCC ICCM glasses were analyzed using XRD. Samples were run under conditions allowing an approximate 1.0vol. $\%$ detection limit. That is, if crystals (or undissolved solids) are present at 1.0 vol.\% (or greater), the diffractometer will not only be capable of detecting these crystals, but will also allow a qualitative measure (i.e., determine the type of crystal[s] present). Otherwise, a characteristic high background devoid of crystalline spectral lines indicates that the glass product is amorphous.

To determine the volume fraction crystallization, selected glass samples were heat treated in Pt alloy crucibles with tight fitting lids at selected temperatures for $24 \mathrm{~h}$ to obtain equilibrium with solid phases that form. The crystal type and content of these samples were determined using XRD. Crystal fraction was determined from cell refinement methodology using Riqas 4.0 software (MDI, Livermore California) with a $\mathrm{CaF}_{2}$ standard. The crystal fractions of selected $\mathrm{CCC}$ samples were also analyzed by this method.

High-temperature $\eta$ was measured as a function of temperature (T) using a spindle viscometer for selected ICCM glasses. The measurements were obtained using standard procedures (SRTC 1999; Schumacher and Peeler 1998), which are compliant with the ASTM C 965-81 [ASTM 1990]. Hightemperature $\eta$ data were measured over the maximum temperature range allowable for each glass.

Electrical conductivity $(\varepsilon)$ was measured as a function of both temperature and frequency for ICCM-2 glass using an opposing plate probe as described previously (Hrma et al. 1994). The results were sufficiently close to model predictions to use glass property models to estimate the $\varepsilon$ of other glasses. 
The PCT was performed on each glass to assess chemical durability via the PCT (ASTM 1998). The PCT was conducted in triplicate for each ICCM glass (both quenched and CCC versions). Also included in this experimental test matrix were the EA glass (Jantzen et al. 1993), the Approved Reference Material (ARM-1) glass, and blanks. Samples were ground, washed, and prepared according to version A of the procedure. Fifteen (15) $\mathrm{mL}$ of Type I ASTM water were added to 1.5 grams of glass in stainless steel vessels. The vessels were closed, sealed, and placed in an oven at $90 \pm 2{ }^{\circ} \mathrm{C}$ for 7 days. The resulting solutions (once cooled) were sampled (filtered and acidified), labeled, and analyzed by ICP-AES. Normalized release rates were calculated based on targeted compositions using the average of the logs of the leachate concentrations. 
Immobilization Technology Section

WSRC-TR-2002-00426

Savannah River Technology Center

Rev. 0

Westinghouse Savannah River Company

This page intentionally left blank. 


\subsection{Results}

\subsection{Chemical Composition}

Appendix A summarizes the target and measured compositions for all the ICCM glasses. Overall, comparisons between the measured and targeted compositions suggest that there were no significant problems in the batching or fabrication of the study glasses.

\subsection{Homogeneity}

Table 6-1 summarizes the visual observations of homogeneity and XRD results for each quenched ICCM glass. Table 6-2 summarizes the visual observations of homogeneity as well as XRD results for each ICCM glass after CCC. Appendix B provides all the XRD patterns for all ICCM glasses (both quenched and $\mathrm{CCC}$ ).

For those ICCM glasses that were visually not homogeneous (e.g., multi-phased), two primary characteristics or features were observed: (1) a dull-brown cross section and (2) a metallic coating, swirls, or haze on the glass surface. Although no scanning electron microscopy-electron dispersive spectroscopy (SEM-EDS) analysis was performed on the ICCM glasses, XRD results indicate the presence of spinels (including magnetite, jacobsite, franklinite, magnesioferrite and/or nepheline) in both the quenched and CCC glasses.

In a separate study, Peeler et al. (2001) determined the formation of spinel-type phases was responsible for similar features. In that study, SEM-EDS analysis of similar dull brown cross-sections indicated the crystals were enriched in $\mathrm{Fe}, \mathrm{Ni}, \mathrm{Mn}$, and $\mathrm{Cr}$ with subsequent XRD analysis identifying various spineltype phases. It was hypothesized that the high density or concentration of crystals in the bulk imparts the dull-brown appearance to the cross section.

As with several ICCM glasses, metallic streaks, spots, coatings, or haze on the top surface of the pour patty also characterized several glasses in that previous study. SEM-EDS and XRD analysis indicated the presence of spinel-type crystals - extremely small and densely populating the surface of these pour patties presumably leading to the metallic appearance observed. Given the identification of spinels in most of the ICCM glasses, it is hypothesized that their presence accounts for the metallic nature or characteristics observed.

It should be noted that in six ICCM quenched glasses there appears to be a discrepancy between the visual observations and XRD results. In five (ICCM-5, -6, -8, -9, and -10) of the six, the presence of a metallic haze or film on the surface of the pour patties was noted by visual observations but XRD results suggest these glasses are homogeneous (single-phase or crystal-free). Samples were run under conditions allowing an approximate $1.0 \mathrm{vol} . \%$ detection limit that may have contributed to this discrepancy. Visual observations of ICCM-13 (quenched) suggested that the glass was single-phase while the XRD detected franklinite $\left(\mathrm{ZnFe}_{2} \mathrm{O}_{4}\right)$. 


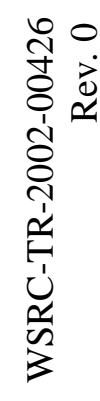
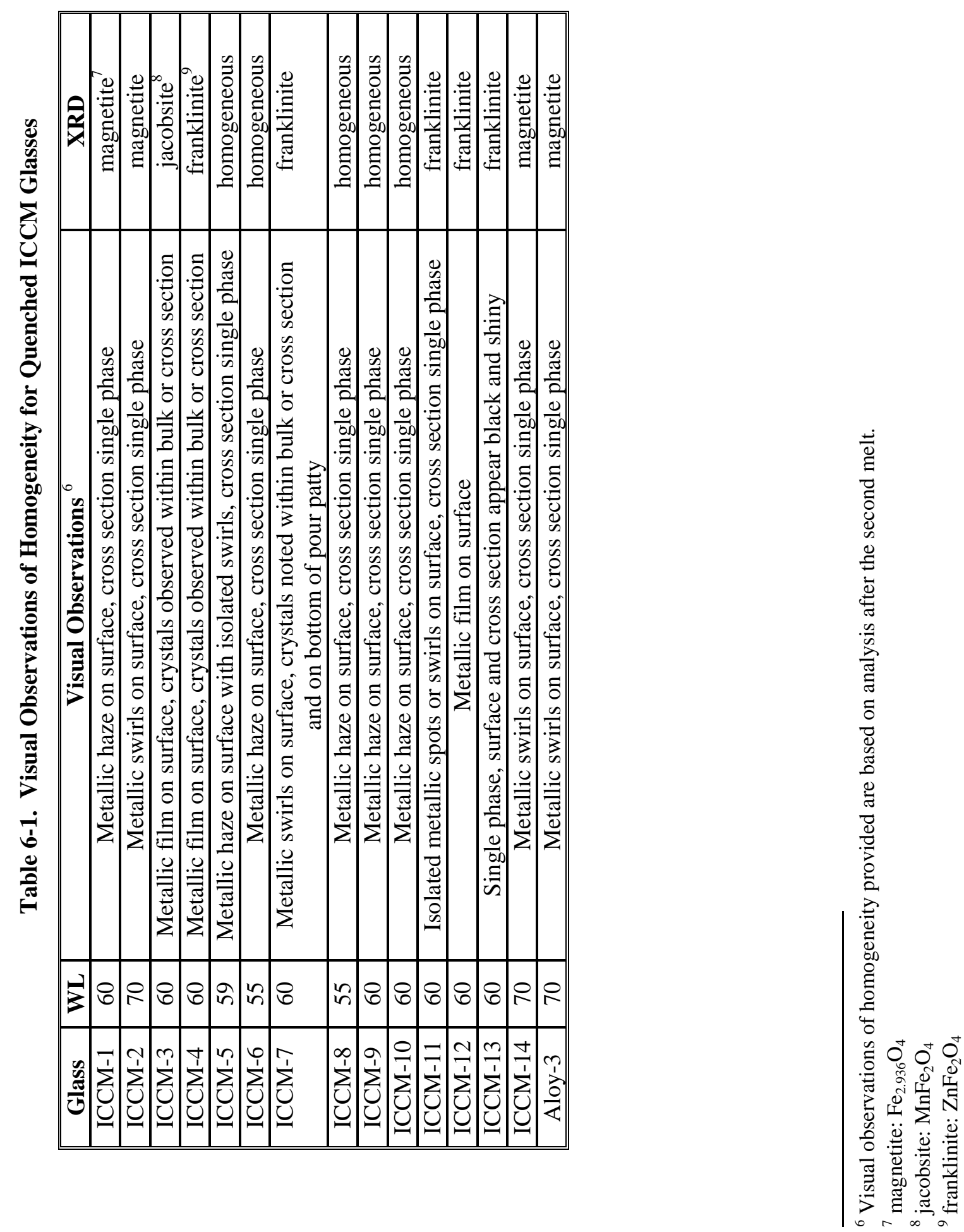


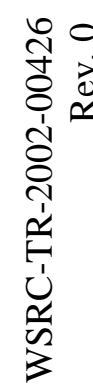

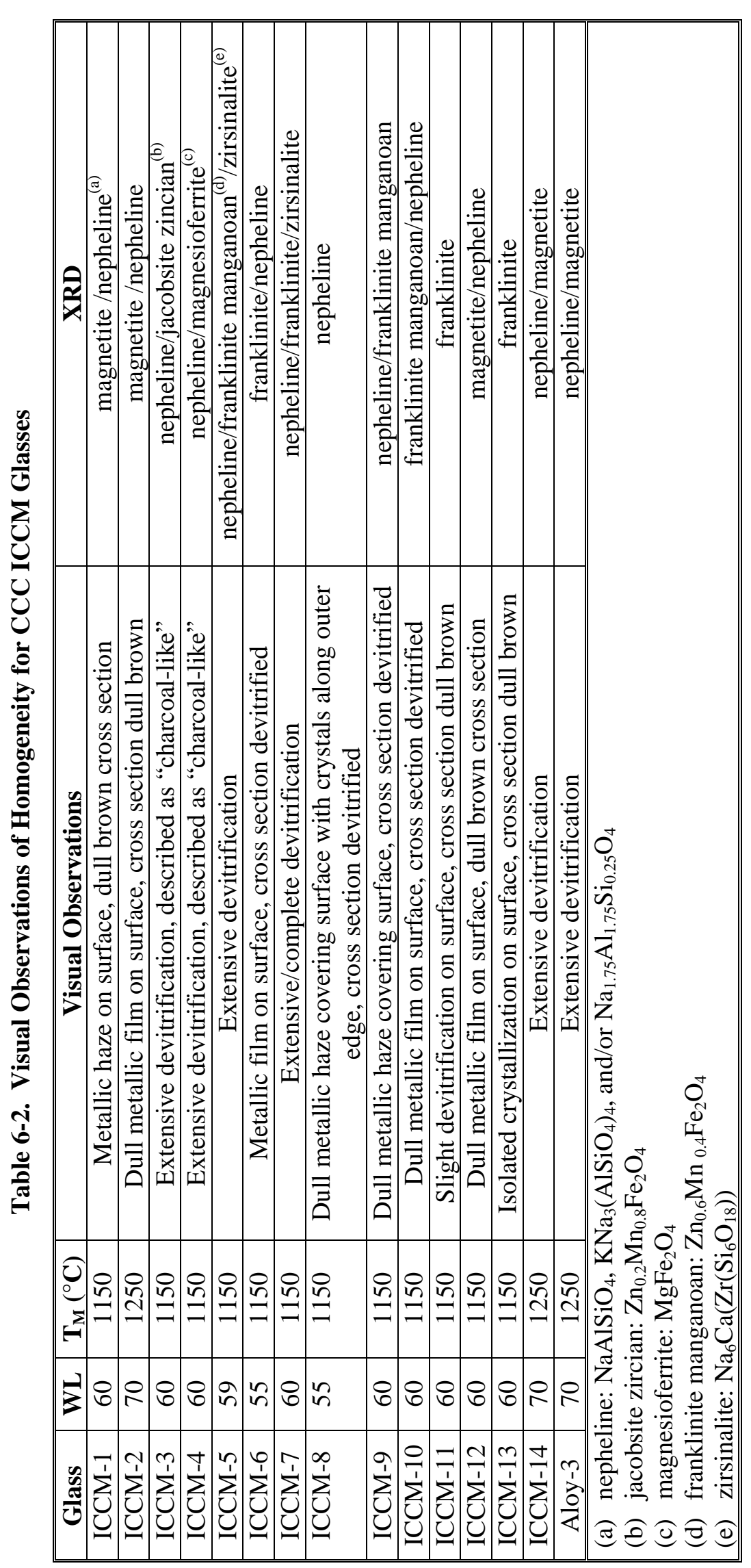




\subsection{Viscosity}

High-temperature viscosity $(\eta)$ was measured as a function of temperature $(T)$ using a spindle viscometer for two ICCM glasses: ICCM-1 (60\% WL) and ICCM-2 (70\% WL). A hysteresis-type approach was used in measuring viscosity that centered on the target $\mathrm{T}_{\mathrm{M}}$. The initial temperature targeted $1250^{\circ} \mathrm{C}$, and was then increased to approximately $1350^{\circ} \mathrm{C}$ in $50^{\circ} \mathrm{C}$ increments then lowered to $1250^{\circ} \mathrm{C}$ for the second viscosity reading at $1250^{\circ} \mathrm{C}$. The higher temperature portion of the hysteresis was followed by a lower portion in which the temperature was decreased to approximately $1150^{\circ} \mathrm{C}$ in $50^{\circ} \mathrm{C}$ increments and then returned to $1250^{\circ} \mathrm{C}$ for a third and final measurement. This approach was used to allow for a measure of the potential impacts of devitrification and/or volatilization. More specifically, if devitrification occurred at a lower temperature and remained suspended in the glass matrix at higher temperatures, their presence may be shown through a different viscosity reading at the target $\mathrm{T}_{\mathrm{M}}$ (assuming no or minimal crystallization at the target $\mathrm{T}_{\mathrm{M}}$ ). If volatilization occurs at temperatures exceeding $\mathrm{T}_{\mathrm{M}}$, higher viscosity readings would be anticipated once temperatures were lowered.

Table 6-3 summarizes the three measured viscosities at $\sim 1250^{\circ} \mathrm{C}$ for both ICCM- 1 and ICCM- 2 . Appendix $\mathrm{C}$ provides all the measured data for both glasses. The measured viscosity readings at $\sim 1250^{\circ} \mathrm{C}$ $\left(\eta_{1250^{\circ} \mathrm{C}}\right)$ for ICCM-1 all appear to be relatively consistent, ranging from $3.32-3.83 \mathrm{~Pa}$-s. This indicates that the viscosity readings were not strongly impacted by the presence of crystallization - this does not rule out the presence of crystals at $\mathrm{T}_{\mathrm{M}}$ but suggests, if present, that they had a minimal impact. ICCM-1 was developed to have a viscosity of $7.5 \mathrm{~Pa} \cdot \mathrm{s}$ at $1200^{\circ} \mathrm{C}$. The measured viscosity at $1200^{\circ} \mathrm{C}$ was approximately 5.5 Pa.s (see Appendix C) - well within the acceptance criterion (see Table 3-1).

Viscosity readings for ICCM-2 are quite "unstable" at $1250^{\circ} \mathrm{C}$ ranging from a low of $6.15 \mathrm{~Pa}-\mathrm{s}\left(2^{\text {nd }}\right.$ reading at $1250^{\circ} \mathrm{C}$ after going to maximum temperature of $\left.\sim 1350^{\circ} \mathrm{C}\right)$ to a high of $10.97 \mathrm{~Pa}-\mathrm{s}\left(3^{\text {rd }}\right.$ reading at $1250^{\circ} \mathrm{C}$ after going to minimum temperature of $\sim 1125^{\circ} \mathrm{C}$ ). The overall instability of the measurements is directly related to crystal formation. As discussed in Section 6.6, subsequent determination of the equilibrium volume fraction crystallization at $1250^{\circ} \mathrm{C}$ indicates approximately 6 vol. $\%$ of spinels. Based on the volume fraction measurements, at temperatures exceeding $1300^{\circ} \mathrm{C}$, no crystals were observed. It is therefore not surprising that the viscosity readings at $1250^{\circ} \mathrm{C}$ were erratic. The measured viscosity at $1350^{\circ} \mathrm{C}$ (the target melt temperature for ICCM-2) was approximately $1.7 \mathrm{~Pa} \cdot \mathrm{s}$ - slightly below the acceptance criteria. This latter statement assumes that there were no crystals at $1350^{\circ} \mathrm{C}$ or that the residual crystals had no or little impact on the measured viscosity. It should be noted that a slight reduction in the nominal processing temperature to $\sim 1325^{\circ} \mathrm{C}$ should bring the viscosity within the "acceptable" range while minimizing or avoiding crystal formation.

Table 6-3. Measured $\eta_{1250^{\circ} \mathrm{C}}$ for the ICCM-1 and ICCM-2 Glasses

\begin{tabular}{||c|c|c||}
\hline \hline Glass ID & Temperature $\left({ }^{\circ} \mathrm{C}\right)$ & Measured $\eta_{1150^{\circ} \mathrm{C}}(\mathrm{Pa}-\mathrm{s})$ \\
\hline ICCM-1 & 1234 & 3.83 \\
\hline & 1248 & 3.32 \\
\hline & 1247 & 3.55 \\
\hline ICCM-2 & 1247 & 8.14 \\
\hline & 1250 & 6.15 \\
\hline & 1246 & 10.97 \\
\hline
\end{tabular}




\subsection{Electrical Conductivity}

The electrical conductivity $(\varepsilon)$ of molten ICCM-2 $(70 \% \mathrm{WL})$ glass was measured - given it was a primary candidate for supporting initial ICCM demonstrations. The $\varepsilon-\mathrm{T}-$ frequency data are listed in Table 6-4 and plotted in Figure 6-1. At 1-kHz frequency and above, the $\varepsilon$ is relatively independent of frequency. At these frequencies, the temperature effect on $\varepsilon$ can be described by an Arrhenius function:

$$
\ln [\varepsilon]=8.2169-7930.1 / \mathrm{T}
$$

where $\mathrm{T}$ is in Kelvin and $\varepsilon$ is in $\mathrm{S} / \mathrm{m}$.

Table 6-4. Electrical Conductivity Data for ICCM-2 (70 mass\% WL) Glass Melt

\begin{tabular}{||c|c|c|c||}
\hline \hline $\mathbf{T}\left({ }^{\circ} \mathbf{C}\right)$ & $\boldsymbol{\varepsilon}(\mathbf{S} / \mathbf{m})$ & Resistance $(\Omega)$ & Freq $(\mathbf{H z})$ \\
\hline 1290 & 22.35 & 1.413 & 100 \\
\hline 1241 & 19.03 & 1.644 & 100 \\
\hline 1192 & 15.68 & 1.644 & 100 \\
\hline 1141 & 12.71 & 2.420 & 100 \\
\hline 1290 & 23.05 & 1.374 & 1000 \\
\hline 1241 & 19.80 & 1.584 & 1000 \\
\hline 1192 & 16.55 & 1.877 & 1000 \\
\hline 1141 & 13.53 & 2.280 & 1000 \\
\hline 1290 & 23.67 & 1.343 & 10000 \\
\hline 1241 & 20.60 & 1.528 & 10000 \\
\hline 1192 & 17.47 & 1.785 & 10000 \\
\hline 1141 & 14.52 & 2.128 & 10000 \\
\hline \hline
\end{tabular}

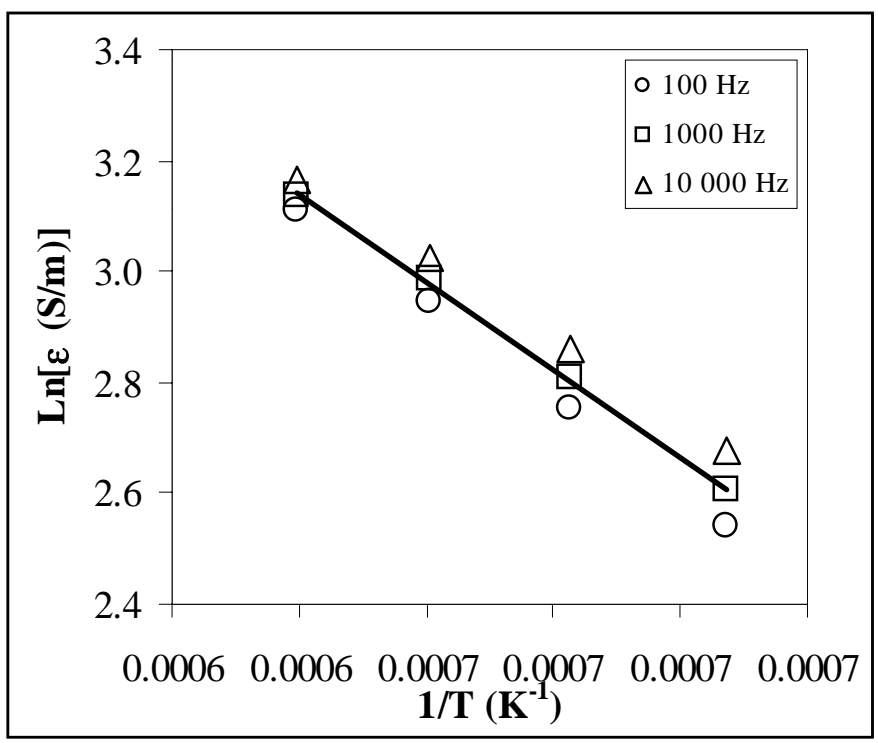

Figure 6-1. Electrical Conductivity of ICCM-2 at 60\% WL Melt as a Function of Inverse Temperature 


\subsection{PCT}

Table 6-5 summarizes the PCT results (in $\mathrm{g} / \mathrm{m}^{2}$ ) for both quenched and CCC ICCM glasses as a function of waste loading. The normalized releases are based on target compositions. As previously stated, the DOE imposed limit set on the PCT response is that the releases of boron, sodium, and lithium, normalized to glass composition, must be significantly less than those of the DWPF EA glass. The normalized releases of boron $\left(\mathrm{r}_{\mathrm{B}}\right)$, sodium $\left(\mathrm{r}_{\mathrm{Na}}\right)$, and lithium $\left(\mathrm{r}_{\mathrm{Li}}\right)$ for the DWPF-EA glass are $8.35 \mathrm{~g} / \mathrm{m}^{2}, 6.67 \mathrm{~g} / \mathrm{m}^{2}$, and $4.78 \mathrm{~g} / \mathrm{m}^{2}$, respectively (Jantzen et al. 1993). For the purposes of this study, we used a conservative upper release limit of $2 \mathrm{~g} / \mathrm{m}^{2}$ for $\mathrm{r}_{\mathrm{B}}, \mathrm{r}_{\mathrm{Na}}$, and $\mathrm{r}_{\mathrm{Li}}$ for acceptability to guide glass formulation efforts. Although a conservative normalized release limit was used, glasses exceeding this limit were tested to gain insight into potential compositional adjustments that would minimize crystal formation with potential adverse impacts on both processability and product quality. It should also be noted that acceptability should not be based on this conservative limit but solely on DOE established criteria. Also shown in Table 6-5 are the crystalline phase(s) identified by XRD for both heat treatments.

Figure 6-2 provides an additional look at the $\mathrm{r}_{\mathrm{B}}\left(\mathrm{g} / \mathrm{m}^{2}\right)$ values for both quenched and CCC versions of the ICCM glasses (note an inset helps highlight the large discrepancy between select quenched and CCC glasses). Statistical analysis of these data indicates a significant difference (on average) between the quenched and CCC versions of these glasses.

For those glasses lying on (or close to) the $45^{\circ}$ line (1:1 correlation), there is little difference between the $\mathrm{r}_{\mathrm{B}}$ of the quenched and CCC versions of that glass. Glasses falling into this category include: ICCM-1, $-2,-11,-12,-13,-14$, and Aloy-3. With respect to the conservative acceptance criteria of $2 \mathrm{~g} / \mathrm{m}^{2}$ used to guide glass formulation efforts, all of these glasses (both quenched and CCC) are acceptable. It should be noted that all of the glasses listed above are acceptable relative to the DOE requirements and thus should not be discounted as potential glasses to support either ICCM or JHCM melter demonstrations assuming all other acceptance criteria are satisfied.

Glasses with relatively large differences between the quenched and CCC versions include: ICCM-3, -4 , $-5,-6,-7,-8,-9$, and -10 . The quenched versions of these glasses (excluding ICCM-9 and -10) meet the conservative $2 \mathrm{~g} / \mathrm{m}^{2}$ limit but the durability is severely impacted upon CCC. Using the $\mathrm{r}_{\mathrm{B}}$ values as a guide, the release values for the CCC versions range from a $3.66 \mathrm{~g} / \mathrm{m}^{2}$ to $39.255 \mathrm{~g} / \mathrm{m}^{2}$. Although the focus of this series of glasses was to minimize equilibrium crystal volume fraction of the melt, an attempt was made to maintain acceptable CCC glass PCT releases. Obviously this is not the case when assessments are made against the conservative criterion. An assessment of the $r_{B}, r_{N a}$, and $r_{L i}$ values indicate that only ICCM-6 and ICCM-8 (out of this series) yield glasses that would be deemed acceptable when compared to the EA limits (ignoring uncertainties). Even though ICCM-6 and ICCM-8 may be acceptable, their releases are relatively high and given other glasses met the established process and product quality acceptance criteria there is no reason to consider these two glasses as potential candidates. It should be noted that the results of ICCM-3 through ICCM-10 guided subsequent formulation efforts in which the balance between minimizing crystalline volume fraction and PCT was obtained. 
官

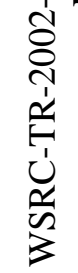

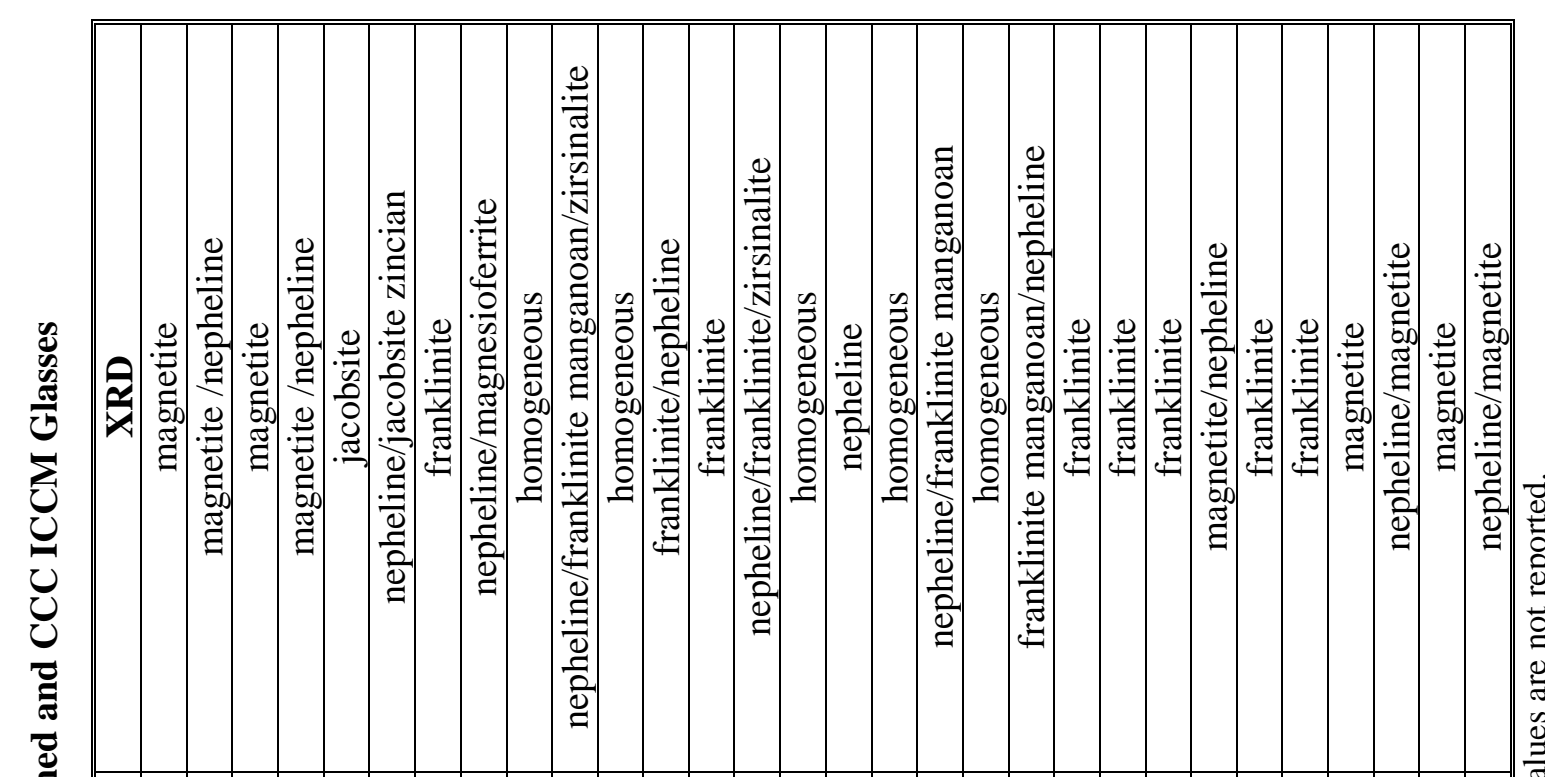

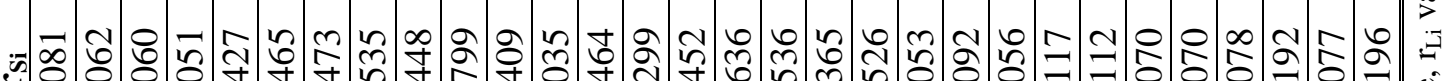

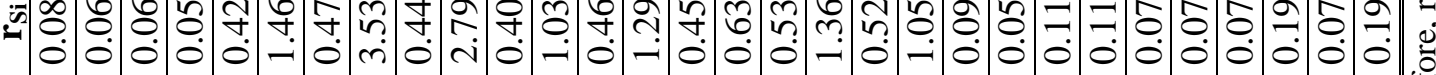

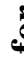

(1)

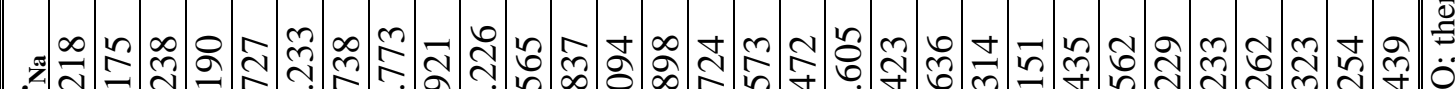

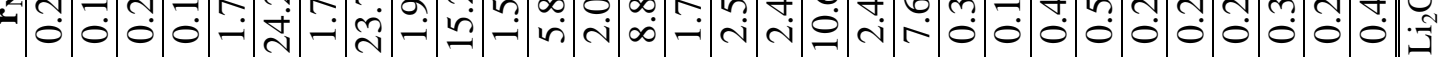

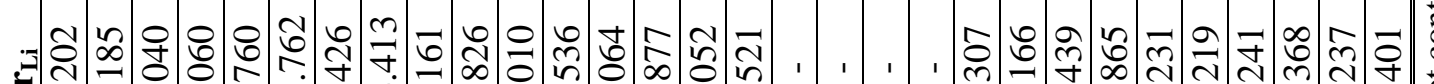

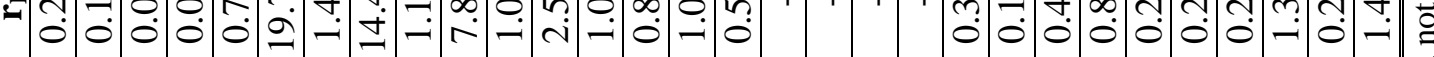

車

के के

응

造造

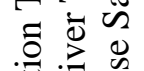

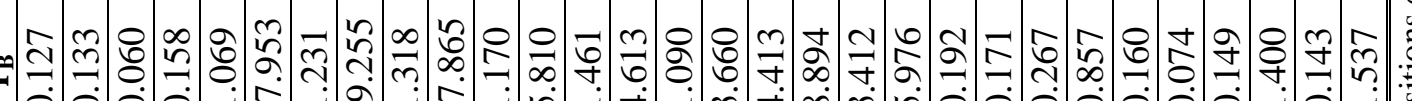

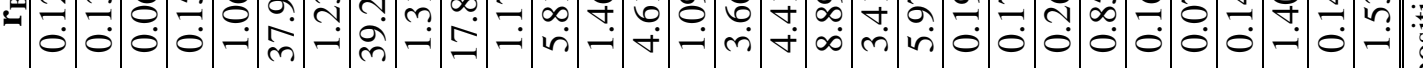

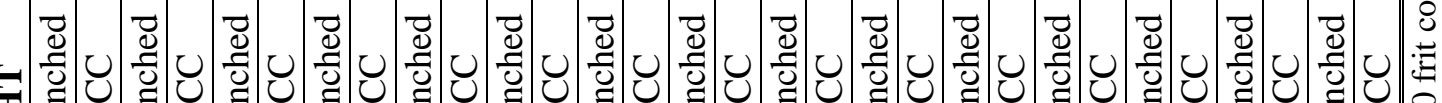

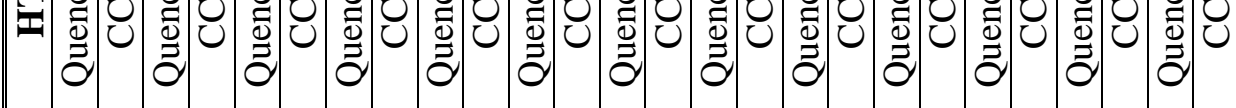

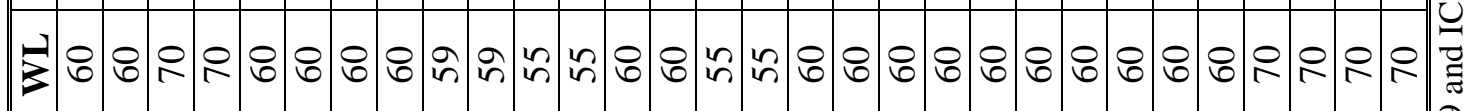

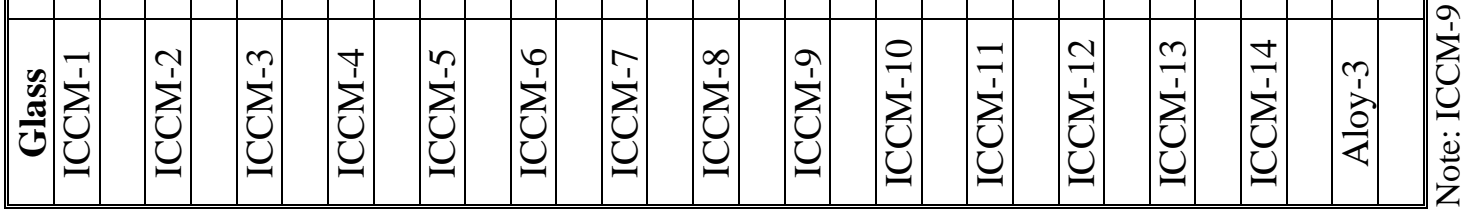

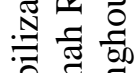

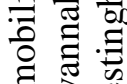

焉芳 


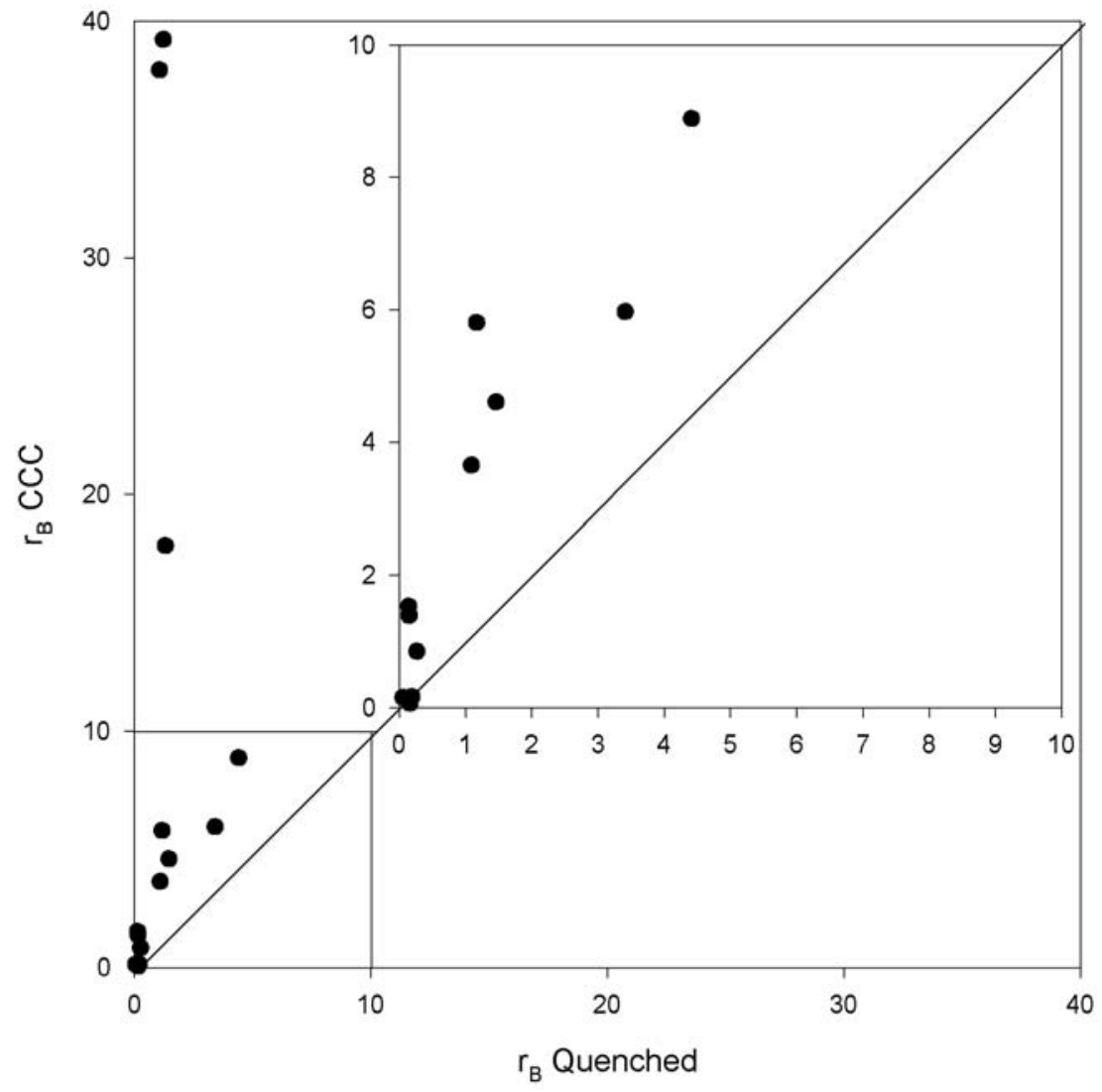

Figure 6-2. $\mathbf{r}_{\mathrm{B}}\left(\mathrm{g} / \mathrm{m}^{2}\right)$ for Quenched vs. CCC ICCM Glasses

\subsubsection{Effect of Crystallization on Durability}

The formation of a new phase affects the glass matrix in which it is embedded, both chemically and mechanically. These changes may impact the rate of glass dissolution in water and thus change its chemical durability (Jantzen and Bickford 1985; Cicero et al. 1993; Kim et al. 1995). Riley et al. (2001) indicated that the residual glass composition was the major factor that controlled the PCT response of HLW glasses with durable crystalline phases. Other chemical or mechanical factors, such as concentration gradients and mechanical stresses, played a secondary role.

The effect of CCC on the PCT of HLW glasses was determined for more than 100 glass compositions (Hrma et al. 1994; Kim et al. 1995), as shown in Figure 6-3. The $r_{B}$ s from CCC and quenched glasses were close in value for most of the compositions regardless of the fraction of crystallinity that formed during heat treatment. The CCC treatment significantly increased $r_{B}$ as compared to quenched for only 18 of these glasses. Six compositions exhibited a moderate increase in $r_{B}$ from CCC glass, and twelve CCCtreated compositions showed a strong increase in $r_{B}$. Those glasses with a moderate increase in $r_{B}$ contained zircon, clinopyroxene, and/or hematite crystals while those with a strong increase in $r_{B}$ contained alkali aluminosilicates (nepheline and eucryptite) and cristobalite. 


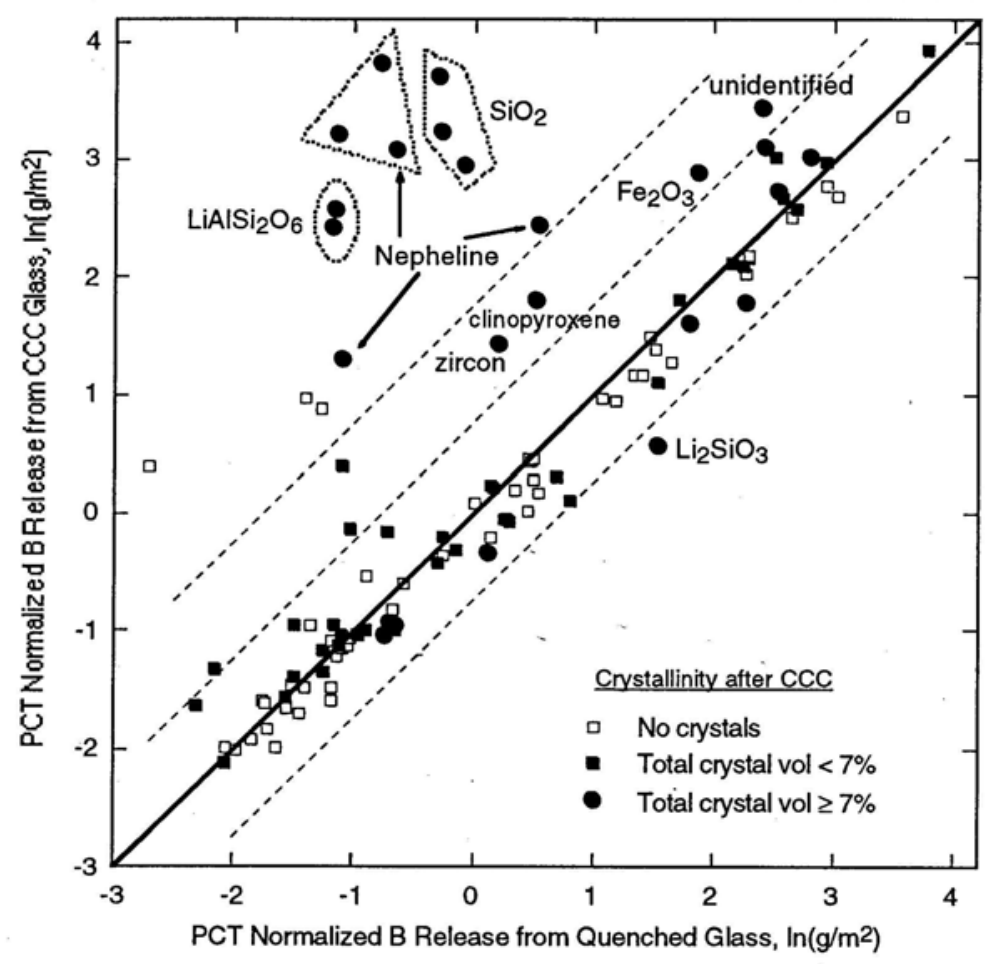

Figure 6-3. In $r_{B}$ from CCC Versus Quenched Glasses Within Hanford Composition Region (Kim et al. 1995)

As previously discussed, glasses formed from wastes high in $\mathrm{Na}$ and $\mathrm{Al}$ are susceptible to nepheline crystallization during cooling, which has been shown to increase the normalized PCT releases of some glasses (Li et al. 1997; Li et al. 1998). In select CCC ICCM glasses, the formation of nepheline is the likely cause of the significant, adverse impact on durability. For example, the quenched version of ICCM-3 contained spinel (jacobsite) while the CCC version contained both spinel and nepheline. The corresponding $r_{B}$ values were 1.069 and $37.953 \mathrm{~g} / \mathrm{m}^{2}$, respectively. The formation of spinel in the quenched glasses appears to have had little to no impact on the durability response - consistent with previous research. Formation of nepheline appears to be the driver for the dramatic reduction in durability upon $\mathrm{CCC}$, yielding $\mathrm{a}_{\mathrm{B}}$ of $37.953 \mathrm{~g} / \mathrm{m}^{2}$ - more than four times the acceptable EA criterion.

Although the formation of nepheline is the primary suspect for the negative impact on durability in some glasses, its formation has little or no impact in other glasses. Consider ICCM-1, -2, -14, and Aloy-3. The quenched versions of these glasses were characterized solely by spinel (magnetite) with $r_{B}$ values on the order of $0.15 \mathrm{~g} / \mathrm{m}^{2}$. The CCC versions of these glasses contained both spinel and nepheline and the corresponding $r_{B}$ values ranged from 0.133 to $1.537 \mathrm{~g} / \mathrm{m}^{2}$. This indicates that the formation of nepheline had little to no impact on the durability of the product - indicating that the residual glass matrix for each of these glasses is durable and acceptable.

\subsection{2 $r_{B}$ Model for CCC Glasses}

Previous attempts to relate $r_{B}$ to glass composition via first- or second-order polynomial functions yielded good results for large composition regions of quenched HLW glasses, but were relatively unsuccessful for 
CCC-treated glasses. When the fraction and composition of the crystalline phase was known, measured $r_{B} \mathrm{~S}$ were in good agreement with those calculated for the composition of the residual glass (Kim et al. 1995; Bailey and Hrma 1995; Hrma and Bailey 1995; Li et al. 1997). A study of high waste-loaded glasses (Bailey and Hrma 1995) indicated that the residual glass composition was the major factor that controlled the PCT response of glasses with durable crystalline phases.

Previous studies showed that precipitation of cristobalite and certain aluminosilicates could decrease chemical durability by several orders of magnitude, whereas severe crystallization of other phases has little or even a positive impact on glass durability. This behavior can be attributed to changes of the residual glass composition associated with crystallization. This effect can be predicted by computing residual glass composition based on the mass balance of components and estimating PCT releases from the residual glass from first-order models that have been developed for crystal-free glasses. Hrma et al. (2001) showed reasonable agreement between calculated and measured values of $r_{B}$ and $r_{N a}$ for over 200 HLW glasses.

Given the success of previous studies and the need to understand or have the ability to "predict" a priori the impact of crystallization on durability, an empirical model was fit to the $r_{B}$ data from ICCM-1 through -10 CCC glass samples. A good linear relationship between $\ln \left[\mathrm{r}_{\mathrm{B}}\right]$ and the varied composition parameters was found as shown in Figure 6-4. The resulting model is summarized in Table 6-6. This model, useful only for glasses fabricated from this waste simulant, was used to develop glasses ICCM-11 through -13 as described in Section 4.0. As discussed in Section 6.5, this series of glasses (both quenched and CCC) were acceptable - even with respect to the conservative $2 \mathrm{~g} / \mathrm{m}^{2}$ criterion.

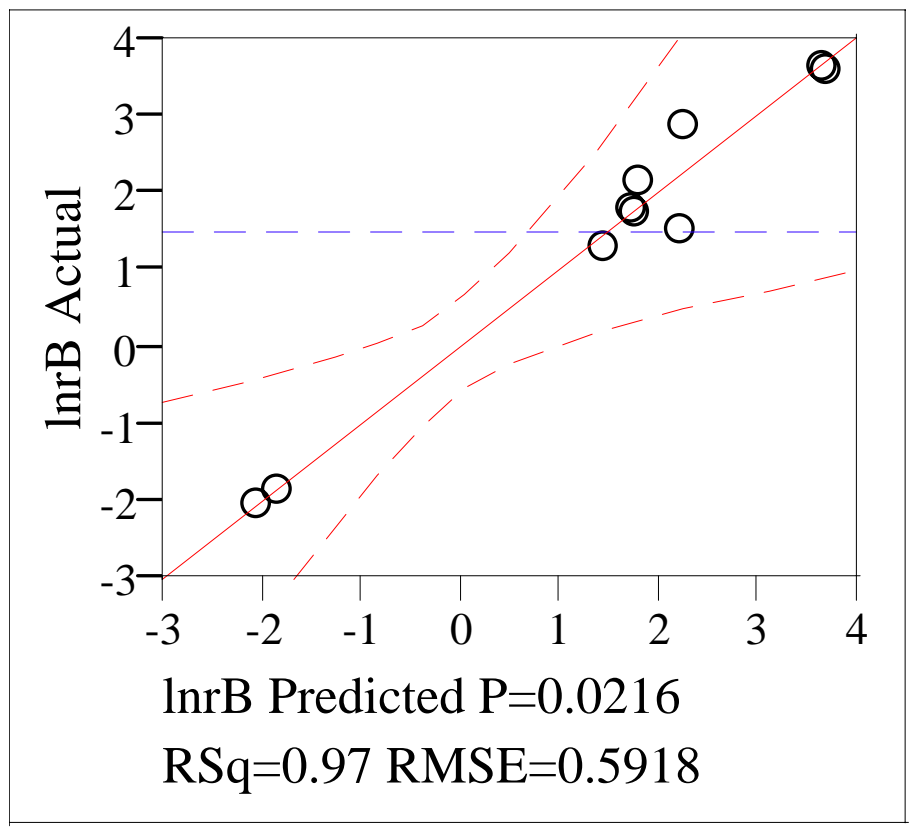

Figure 6-4. Comparison of Measured and Predicted $\ln \left[\mathrm{r}_{\mathrm{B}}\right]$ from CCC ICCM Glasses 
Table 6-6. $\ln \left[\mathrm{r}_{\mathrm{B}}\right]$ Model Summary

\begin{tabular}{|l|r|r||}
\hline \hline Component & Coefficient & Standard Error \\
\hline $\mathrm{B}_{2} \mathrm{O}_{3}$ & -29.40 & 37.89 \\
\hline $\mathrm{K}_{2} \mathrm{O}$ & 55.02 & 11.10 \\
\hline $\mathrm{Li}_{2} \mathrm{O}$ & 121.97 & 83.28 \\
\hline $\mathrm{Na}_{2} \mathrm{O}$ & 37.19 & 4.99 \\
\hline $\mathrm{P}_{2} \mathrm{O}_{5}$ & -7.72 & 55.44 \\
\hline $\mathrm{SiO}_{2}$ & -35.32 & 21.22 \\
\hline Waste & 10.57 & 7.11 \\
\hline & & \\
\hline Statistic & Value & \\
\hline $\mathrm{R}^{2}$ & 0.970 & \\
\hline $\mathrm{R}_{\text {adj }}{ }^{2}$ & 0.911 & \\
\hline $\mathrm{S}$ (RMSE) & 0.592 & \\
\hline Mean & 1.49 & \\
\hline \hline
\end{tabular}

\subsection{Crystal Fraction Results}

The crystal fraction results are tabulated in Table 6-7. The two primary phases identified in these glasses were nepheline $\left(\mathrm{NaAlSiO}_{4}\right)$ and spinel $\left([\mathrm{Fe}, \mathrm{Mn}, \mathrm{Ni}][\mathrm{Fe}, \mathrm{Cr}, \mathrm{Mn}]_{2} \mathrm{O}_{4}\right)$. The end member of the spinel solid solution that most closely matched the crystal structure found in most samples was that of jacobsite $\left(\mathrm{MnFe}_{2} \mathrm{O}_{4}\right)$. SEM/EDS analyses of ICCM-2 heat-treated glass confirmed a spinel with the composition of $\left[\mathrm{Mn}_{1.18}, \mathrm{Ni}_{0.04}\right]_{1.22}\left[\mathrm{Fe}_{1.79}, \mathrm{Cr}_{0.02}, \mathrm{Al}_{0.15}\right]_{1.96} \mathrm{O}_{4}$. SEM micrographs are shown in Figure 6-5. The crystal volume fraction of these samples appear to fit the temperature relationship derived by Vienna (1997) assuming an ideal solution:

$$
\frac{C_{0}}{C_{0, \max }}=1-\exp \left[-B_{L}\left(\frac{1}{T}-\frac{1}{T_{L}}\right)\right]
$$

where $\mathrm{C}_{0}$ and $C_{0, \max }$ are the equilibrium crystal fractions at temperature, $\mathrm{T}$, and extrapolated to low temperature, respectively; and $B_{L}$ is a temperature independent factor related to heat of crystal formation. This behavior is shown in Figure 6-6.

Table 6-7. Crystal Fraction in ICCM Test Glasses (in mass\%)

\begin{tabular}{||c|c|c|c|c||}
\hline Glass ID & $\mathrm{T}\left({ }^{\circ} \mathrm{C}\right)$ & $\begin{array}{c}\text { spinel } \\
\left(\mathrm{MnFe}_{2} \mathrm{O}_{4}\right)\end{array}$ & $\begin{array}{c}\text { nepheline } \\
\left(\mathrm{NaAlSiO}_{4}\right)\end{array}$ & $\begin{array}{c}\text { gehlenite } \\
\left(\mathrm{Sr}_{2} \mathrm{Al}_{2} \mathrm{SiO}_{7}\right)\end{array}$ \\
\hline ICCM-1 & 751 & 0.171 & 0.314 & 0.103 \\
\hline ICCM-1 & 900 & 0.085 & 0.024 & -- \\
\hline ICCM-1 & 1001 & 0.059 & -- & -- \\
\hline ICCM-1 & 1050 & 0.055 & -- & -- \\
\hline ICCM-1 & 1156 & 0.028 & -- & -- \\
\hline ICCM-2 & 751 & 0.092 & 0.418 & -- \\
\hline ICCM-2 & 901 & 0.125 & 0.387 & -- \\
\hline
\end{tabular}


Immobilization Technology Section

WSRC-TR-2002-00426

Savannah River Technology Center

Rev. 0

Westinghouse Savannah River Company

\begin{tabular}{|c|c|c|c|c|}
\hline Glass ID & $\mathrm{T}\left({ }^{\circ} \mathrm{C}\right)$ & $\begin{array}{c}\text { spinel } \\
\left(\mathrm{MnFe}_{2} \mathrm{O}_{4}\right)\end{array}$ & $\begin{array}{c}\text { nepheline } \\
\left(\mathrm{NaAlSiO}_{4}\right)\end{array}$ & $\begin{array}{c}\text { gehlenite } \\
\left(\mathrm{Sr}_{2} \mathrm{Al}_{2} \mathrm{SiO}_{7}\right)\end{array}$ \\
\hline ICCM-2 & 1001 & 0.117 & 0.206 & -- \\
\hline ICCM-2 & 1101 & 0.111 & -- & -- \\
\hline ICCM-2 & 1201 & 0.062 & -- & -- \\
\hline ICCM-2 & 1250 & 0.025 & -- & -- \\
\hline ICCM-2 & $\mathrm{CCC}$ & 0.132 & 0.2634 & -- \\
\hline ICCM-2 & Quench & 0.042 & & -- \\
\hline ICCM-3 & 900 & 0.063 & 0.316 & -- \\
\hline ICCM-3 & 1001 & 0.052 & -- & -- \\
\hline ICCM-3 & 1050 & 0.037 & -- & -- \\
\hline ICCM-3 & 1098 & 0.023 & -- & -- \\
\hline ICCM-4 & 900 & 0.065 & 0.332 & -- \\
\hline ICCM-4 & 1001 & 0.055 & 0.082 & -- \\
\hline ICCM-4 & 1050 & 0.049 & -- & -- \\
\hline ICCM-4 & 1098 & 0.033 & -- & -- \\
\hline ICCM-4 & 1149 & 0.011 & -- & -- \\
\hline ICCM-4 & $\mathrm{CCC}$ & 0.079 & 0.454 & 0.111 \\
\hline ICCM-5 & 900 & 0.065 & 0.211 & -- \\
\hline ICCM-5 & 1000 & 0.038 & -- & -- \\
\hline ICCM-5 & 1050 & 0.035 & -- & -- \\
\hline ICCM-5 & 1148 & 0.004 & -- & -- \\
\hline ICCM-6 & 751 & 0.060 & 0.262 & 0.023 \\
\hline ICCM-6 & 999 & 0.039 & -- & -- \\
\hline ICCM-6 & 1051 & 0.016 & -- & -- \\
\hline ICCM-6 & 1148 & 0.000 & -- & -- \\
\hline ICCM-7 & 999 & 0.048 & -- & -- \\
\hline ICCM-7 & 1054 & 0.037 & -- & -- \\
\hline ICCM-7 & 1148 & 0.003 & -- & -- \\
\hline ICCM-8 & 999 & 0.032 & -- & -- \\
\hline ICCM-8 & 1054 & 0.010 & -- & -- \\
\hline ICCM-9 & 999 & 0.046 & -- & -- \\
\hline ICCM-9 & 1050 & 0.034 & -- & -- \\
\hline ICCM-9 & 1099 & 0.015 & -- & -- \\
\hline ICCM-9 & 1148 & 0.000 & -- & -- \\
\hline ICCM-10 & 999 & 0.049 & -- & -- \\
\hline ICCM-10 & 1048 & 0.032 & -- & -- \\
\hline ICCM-10 & 1101 & 0.025 & -- & -- \\
\hline ICCM-11 & 999 & 0.061 & -- & -- \\
\hline ICCM-11 & 1048 & 0.052 & -- & -- \\
\hline ICCM-11 & 1101 & 0.038 & -- & -- \\
\hline ICCM-11 & 1149 & 0.021 & -- & -- \\
\hline ICCM-11 & $\mathrm{CCC}$ & 0.073 & -- & -- \\
\hline ICCM-12 & 1000 & 0.051 & -- & -- \\
\hline ICCM-12 & 1048 & 0.047 & -- & -- \\
\hline ICCM-12 & 1149 & 0.013 & -- & -- \\
\hline ICCM-12 & $\mathrm{CCC}$ & 0.033 & 0.215 & -- \\
\hline ICCM-13 & 1000 & 0.054 & -- & -- \\
\hline ICCM-13 & 1048 & 0.038 & -- & -- \\
\hline ICCM-13 & 1101 & 0.041 & -- & -- \\
\hline ICCM-13 & 1148 & 0.018 & -- & -- \\
\hline
\end{tabular}




\begin{tabular}{||c|c|c|c|c||}
\hline Glass ID & $\mathrm{T}\left({ }^{\circ} \mathrm{C}\right)$ & $\begin{array}{c}\text { spinel } \\
\left(\mathrm{MnFe}_{2} \mathrm{O}_{4}\right)\end{array}$ & $\begin{array}{c}\text { nepheline } \\
\left(\mathrm{NaAlSiO}_{4}\right)\end{array}$ & $\begin{array}{c}\text { gehlenite } \\
\left(\mathrm{Sr}_{2} \mathrm{Al}_{2} \mathrm{SiO}_{7}\right)\end{array}$ \\
\hline ICCM-13 & CCC & 0.067 & -- & -- \\
\hline ICCM-14 & Quench & 0.112 & -- & -- \\
\hline ICCM-14 & CCC & 0.142 & 0.494 & -- \\
\hline ALLOY-3 & Quench & 0.083 & -- & -- \\
\hline ALLOY-3 & CCC & 0.142 & 0.529 & -- \\
\hline
\end{tabular}
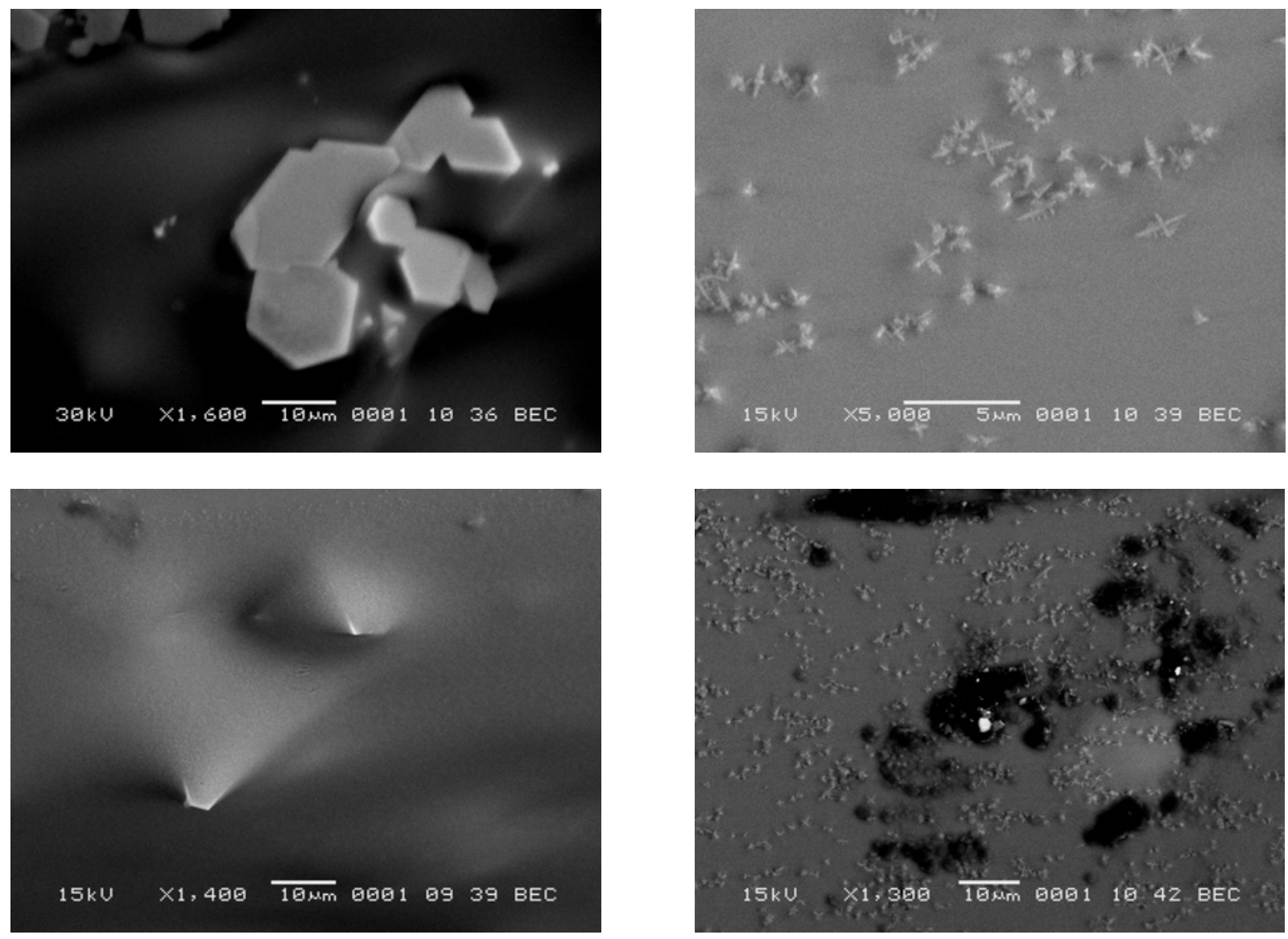

Figure 6-5. SEM Micrographs of Spinel in ICCM-2 Heat-treated Glass 


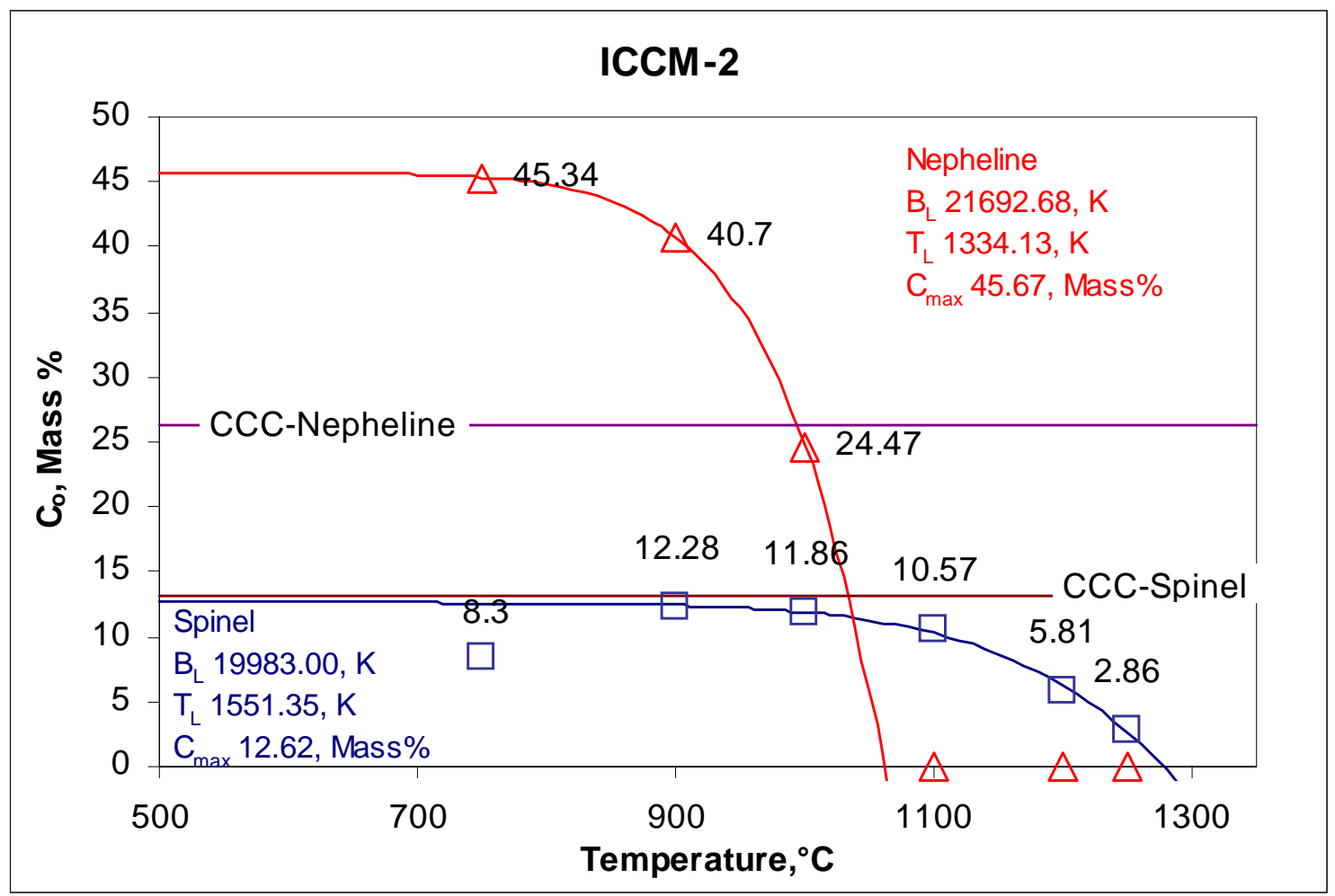

Figure 6-6. Equilibrium Crystal Fraction in ICCM-2 as a Function of Temperature.

Table 6-8. Fitted Values of $B_{L}, T_{L}$, and $C_{\max }$ Along with Calculated and Measured Crystallinity at $1050^{\circ} \mathrm{C}$.

\begin{tabular}{|c|c|c|c|c|c|c|}
\hline Glass ID & 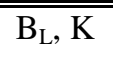 & 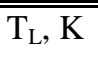 & 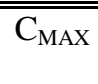 & 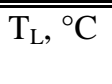 & 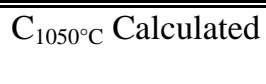 & $\begin{array}{c}\mathrm{C}_{1050^{\circ} \mathrm{C}} \\
\text { Measured }\end{array}$ \\
\hline ICCM-1 & 20000 & 1487 & 0.067 & 1214 & 0.054 & 0.055 \\
\hline ICCM-2 & 19983 & 1551 & 0.126 & 1278 & 0.113 & NA \\
\hline ICCM-3 & 15000 & 1421 & 0.071 & 1148 & 0.039 & 0.037 \\
\hline ICCM-4 & 16000 & 1446 & 0.072 & 1173 & 0.046 & 0.049 \\
\hline ICCM-5 & 10000 & 1429 & 0.078 & 1156 & 0.033 & 0.035 \\
\hline ICCM-6 & 24000 & 1348 & 0.060 & 1075 & 0.017 & 0.016 \\
\hline ICCM-7 & 15000 & 1427 & 0.067 & 1154 & 0.038 & 0.037 \\
\hline ICCM-8 ${ }^{\text {(a) }}$ & NA & NA & NA & 1078 & NA & 0.010 \\
\hline ICCM-9 & 15000 & 1404 & 0.069 & 1131 & 0.033 & 0.034 \\
\hline ICCM-10 & 15000 & 1435 & 0.062 & 1162 & 0.037 & 0.032 \\
\hline ICCM-11 & 15000 & 1466 & 0.077 & 1193 & 0.052 & 0.052 \\
\hline ICCM-12 & 25000 & 1443 & 0.058 & 1170 & 0.046 & 0.047 \\
\hline ICCM-13 & 30000 & 1452 & 0.053 & 1179 & 0.046 & 0.038 \\
\hline
\end{tabular}

(a) $\mathrm{T}_{\mathrm{L}}$ of ICCM-8 glass was determined using a liner fit to data because the data will not support fitting Equation 6-2. 
An empirical model was fit to the $1050^{\circ} \mathrm{C}$ spinel fraction $\left(\mathrm{C}_{0,1050}\right)$ data from the ICCM-1 through -10 glasses. Where data at $1050^{\circ} \mathrm{C}$ was not measured, the spinel fraction was interpolated using the function described above. A good linear relationship between $\mathrm{C}_{0,1050}$ and the varied composition parameters was found as shown in Figure 6-7. The resulting model is summarized in Table 6-8. This model, useful only for glasses fabricated from this waste simulant, was used to develop glasses ICCM-11 through -13 as described in Section 4.0.

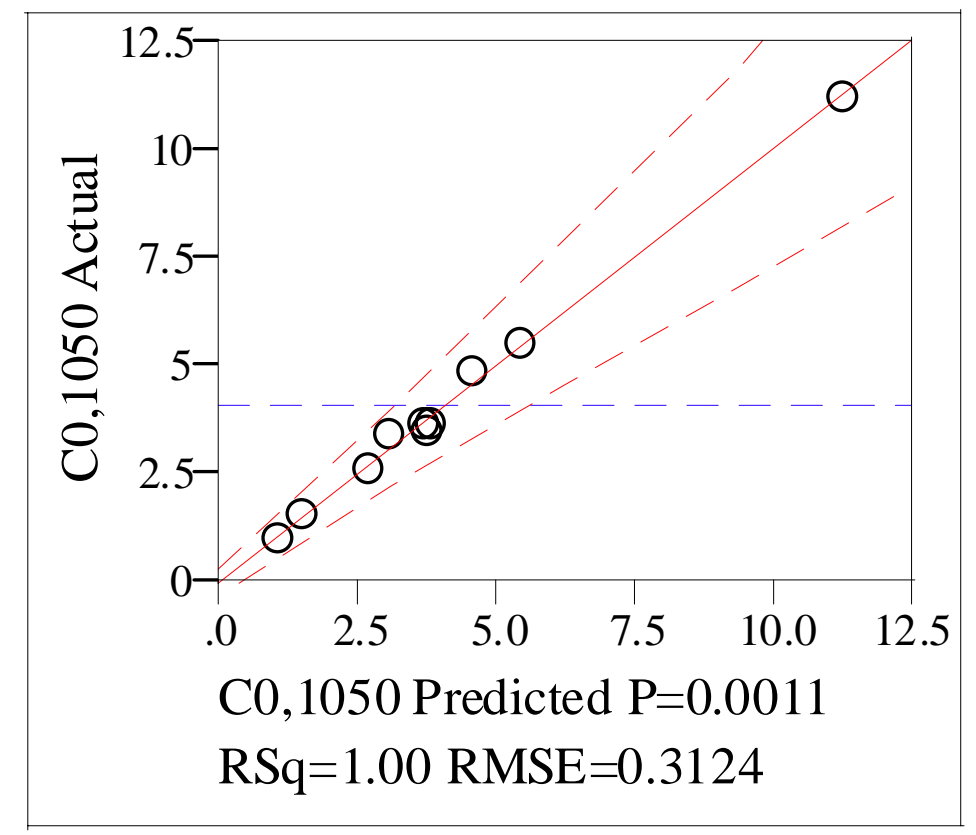

Figure 6-7. Comparison of Measured and Predicted $\mathrm{C}_{0,1050}$ Values in Mass\%

Table 6-8. $\mathrm{C}_{0,1050}$ Model Summary

\begin{tabular}{||l|r|r||}
\hline Component & Coefficient & Standard Error \\
\hline $\mathrm{B}_{2} \mathrm{O}_{3}$ & -63.42 & 20.00 \\
\hline $\mathrm{K}_{2} \mathrm{O}$ & -32.52 & 5.86 \\
\hline $\mathrm{Li}_{2} \mathrm{O}$ & -1.56 & 43.96 \\
\hline $\mathrm{Na}_{2} \mathrm{O}$ & -46.76 & 2.64 \\
\hline $\mathrm{P}_{2} \mathrm{O}_{5}$ & -1.68 & 29.26 \\
\hline $\mathrm{SiO}_{2}$ & -22.30 & 11.20 \\
\hline Waste & 27.37 & 3.75 \\
\hline & & \\
\hline Statistic & Value & \\
\hline $\mathrm{R}^{2}$ & 0.996 & \\
\hline $\mathrm{R}_{\text {adj }}{ }_{\text {adj }}$ & 0.988 & \\
\hline $\mathrm{S}$ (RMSE) & 0.312 & \\
\hline Mean & 4.11 & \\
\hline \hline
\end{tabular}


Immobilization Technology Section

WSRC-TR-2002-00426

Savannah River Technology Center

Rev. 0

Westinghouse Savannah River Company

This page intentionally left blank. 


\subsection{Summary}

Waste streams at the U.S. Department of Energy's (DOE's) Hanford and Savannah River sites contain a varied array of chemical compounds, a number of which can limit the waste loading or cause operating difficulties with melt rate or equipment corrosion. One such stream is the Hanford C-106/AY-102 High Level Waste simulant which represents a blend of tanks that will be processed during initial HLW vitrification efforts at Hanford. The non-radioactive surrogate is based on a specific Hanford waste stream but will also provide valuable information to the Savannah River Site (SRS) - given the relatively high concentrations of $\mathrm{Fe}_{2} \mathrm{O}_{3}, \mathrm{Cr}_{2} \mathrm{O}_{3}$, and $\mathrm{Al}_{2} \mathrm{O}_{3}$ and the cross-cutting assessment of the Strontium/TRU precipitation or permanganate-based pretreatment process being considered at both sites.

The vitrification programs at Hanford and Savannah River may benefit from higher temperature glass formulations that are processable in advanced melters. In many cases, higher melt temperatures permit higher waste loadings in the glass given that the solubility limits of refractory components, such as aluminum, zirconium, and chromium, can be increased. Perez et al. (2001) indicated that the ability to process glasses (given any melter technology) with a higher volume fraction of crystallization would also permit higher loadings of many HLW's in glass.

It has been proposed that the induction-heated, cold-crucible melter (ICCM) technology may be able to achieve these higher temperatures while also being less susceptible to corrosion by high halide and sulfate feeds than current high-level waste (HLW) melters, because of the formation of a cold glass layer at the glass/crucible interface. It has also been proposed that this melter technology is resistant to noble metal electrical shorting because of strong convection currents and the cold glass layer adjacent to the crucible. This technology may provide a higher tolerance for solid phases in the melt without adversely affecting processing.

It has also been proposed (Hrma et al. 2002) that standard Joule-heated ceramic-melters (JHCM) may be able to operate effectively with greater crystal solid fraction than is currently allowed. Hrma et al. (2002) have shown that the major factor controlling sludge accumulation within the melter is crystal size rather than liquidus temperature $\left(\mathrm{T}_{\mathrm{L}}\right)$. The first step toward demonstrating the feasibility of changing the current $\mathrm{T}_{\mathrm{L}}$-based limit for JHCMs is to operate scaled melters and characterize the fate and distribution of crystals formed.

The focus of this report was on the glass formulation activities in support of the ICCM and JHCM demonstrations with C-106/AY-102 simulant. The intent is to provide preliminary (non-optimized) glass formulations for a specific waste stream that met processing requirements, DOE product quality specifications, and programmatic objectives for the two melter types.

A number of glasses were developed for specific loadings of the C106/AY102 simulant (with pretreatment products) using glass property-composition models. These models include: Arrhenius viscosity model (Vienna et al. 2002), Arrhenius electrical conductivity model (Hrma et al. 1994), logarithm PCT release models for quenched glasses (Vienna et al. 2002), nepheline formation estimate (Li et al. 1998), and spinel volume fraction estimate (Hrma and Vienna 2003). It should be noted that the glasses fabricated were outside of the valid composition region for all property models used. Therefore, property models were only useful as rough indicators of properties and could not be relied upon for accurate property prediction. 
As various properties were measured for initial glasses, a strategy developed which was based on a balanced approach regarding the volume percent crystallization with the potential formation of nepheline and its ultimate impact on product quality. Two models were developed that provided the technical basis for this balanced approach as glass compositions at relatively high waste loadings ( $\geq 60$ mass $\%$ ) were developed to meet pre-defined process and product performance acceptance criteria. These models included predictions for $\mathrm{r}_{\mathrm{B}}$ of CCC glasses and for the volume fraction crystallization.

In general, the glasses developed (with waste loadings of $\geq 60$ mass $\%$ ) were very prone to devitrification (especially upon CCC). The PCT response was primarily driven by the type and extent of crystallization and its ultimate impact on the residual glass matrix. Although the formation of nepheline was the primary suspect for the negative impact on durability in some glasses, its formation had little or no impact in other glasses. In four glasses (ICCM-1, -2, -14, and Aloy-3), the quenched versions were characterized solely by spinel (magnetite) with $\mathrm{r}_{\mathrm{B}}$ values on the order of $0.15 \mathrm{~g} / \mathrm{m}^{2}$. The CCC versions of these glasses contained both spinel and nepheline and the corresponding $\mathrm{r}_{\mathrm{B}}$ values ranged from 0.133 to $1.537 \mathrm{~g} / \mathrm{m}^{2}$. This suggests that the formation of nepheline had little to no impact on the durability of the product indicating that the residual glass matrix for each of these glasses is durable and acceptable.

Chronologically, ICCM-2 was recommended to support initial ICCM demonstrations in Russia given that the glass met all of the pre-defined acceptance criteria. The initial ICCM tests using ICCM-2 indicated potential processing difficulties. ${ }^{10}$ Circumstantial evidence from the test suggested that temperatures near the bottom of the melter were as low as $1100^{\circ} \mathrm{C}$ resulting in crystallization of spinel and nepheline in relatively large concentrations.

Given these uncertainties, it was determined that a new formulation should be developed with lower propensity for nepheline formation and, more importantly, a lower viscosity and lower slope of the logarithm viscosity versus inverse temperature relationship (increased length). ICCM-14 was developed to meet these requirements while maintaining a waste loading of 70 mass $\%$ and adequate processing and product quality properties. An additional frit, Aloy-3, was developed by researchers at KRI as a potential candidate for use in follow-on tests. Its composition and properties are similar to those of ICCM-14. The U.S. investigators recommended that either ICCM-14 or Aloy-3 be used on subsequent tests at KRI. Pending a review of their respective properties, researchers at KRI determined which glass was more suited for this technology.

With respect to supporting a JHCM demonstration, ICCM-13 (60 mass\% WL glass) was recommended as this glass met all processing and product performance criteria. The high waste loadings in a JHCM for this particular waste stream can only be achieved by balancing the glass composition so that the crystal content in the melt is minimized (e.g., increasing $\mathrm{Na}_{2} \mathrm{O}$ and other alkali) while minimizing the PCT release from CCC glass (e.g., reducing $\mathrm{Na}_{2} \mathrm{O}$ and other alkali). The recommendation was made in light of pre-existing knowledge of the potential for a limited amount of devitrification at $\mathrm{T}_{\mathrm{M}}$. This will challenge the existing (and potentially conservative) $\mathrm{T}_{\mathrm{L}}$ processing criterion driving most JHCM glass formulations (e.g., $\mathrm{T}_{\mathrm{L}}<1050^{\circ} \mathrm{C}$ ). Goles et al. (2002) provide a summary of the JHCM demonstration using ICCM-13.

\footnotetext{
${ }^{10}$ C.C. Herman, Meeting Minutes for Planning Meeting with Khlopin for High Alkaline Waste Testing, SRT-GPD2002-00107, August 13, 2002.
} 


\subsection{Kholpin Demonstration: ICCM-2}

The KRI has initiated cold-crucible induction-heated melter testing with the alkaline simulant. This testing is being performed to determine the suitability of the technology for the alkaline waste surrogate as outlined by Herman et al. (2002b). In this run plan, ICCM-2 (a 70 mass\% WL glass) was recommended for processing given it met the target process and product quality criteria. Slurry feeding was not performed in this initial testing. To start-up the melter, the feed was placed in the crucible along with lumps of silicon carbide. The silicon carbide was used as sacrificial conductive material to initiate the melting. Once the feed materials were reacted (nominal target melt temperature of $1200^{\circ} \mathrm{C}$ ) and the desired properties were observed, the melter was shut-down and the glass monolith was allowed to cool (within the melter shell). This monolith was removed and sectioned for characterization by Khlopin and the US DOE participants (see Figure 8-1). This monolith was approximately half the diameter of the 155$\mathrm{mm}$ crucible. Although Herman and Peeler (2002) provided a more thorough discussion of this sample and the results, a brief summary is provided in this report for comparison purposes.

As shown in Figure 8-1, the ICCM-2 monolith was visually characterized by two distinct regions: (1) an exterior region that visually appeared to contain a high degree of crystallization and (2) an interior region which appeared "glassy" - black and shiny. Samples from each distinct region were obtained and characterized for chemical composition, crystallization, and durability using the Product Consistency Test (PCT). In this section, the results of this limited characterization are presented and general comparisons are made to the ICCM-2 glass produced by the US DOE participants. 


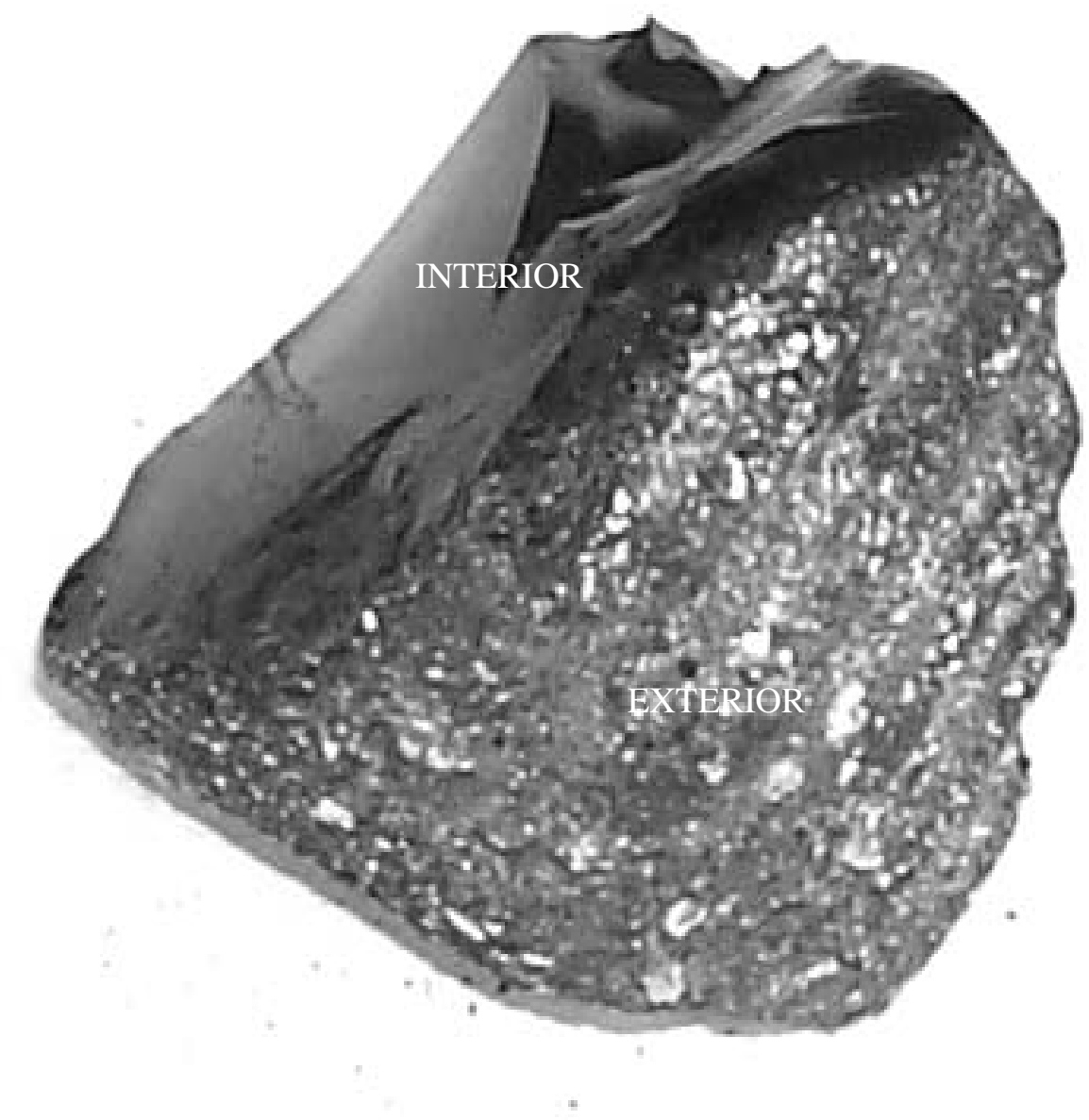

Figure 8-1. Sample of ICCM-2 Glass Received from Kholpin (monolith was approximately half the diameter of the $155-\mathrm{mm}$ crucible)

\subsection{Results}

\subsubsection{Compositional Analysis}

Due to the anticipated high degree of crystallization in the "exterior" sample, a representative sample of the interior section was obtained and submitted for compositional analysis. This sample should more closely represent the targeted ICCM-2 composition and the bulk glass that will be processed in subsequent melter runs. The glass sample was dissolved using lithium metaborate and sodium peroxide fusions and analyzed using ICP-AES. The measured compositional results are provided in Table 8-1 along with the target ICCM-2 composition. 
Table 8-1. Chemical Composition of the Glass Produced in Khlopin Testing (mass\%)

\begin{tabular}{|c|c|c|}
\hline $\begin{array}{l}\text { Oxide/ } \\
\text { Species }\end{array}$ & $\begin{array}{c}\text { Target } \\
\text { Composition }\end{array}$ & $\begin{array}{c}\text { Measured } \\
\text { Composition }\end{array}$ \\
\hline $\mathrm{Ag}_{2} \mathrm{O}$ & 0.32 & NM \\
\hline $\mathrm{Al}_{2} \mathrm{O}_{3}$ & 14.79 & 14.2 \\
\hline $\mathrm{B}_{2} \mathrm{O}_{3}$ & 3.00 & 3.19 \\
\hline $\mathrm{BaO}$ & 0.09 & 0.12 \\
\hline $\mathrm{CaO}$ & 0.98 & 0.852 \\
\hline $\mathrm{CdO}$ & 0.06 & $<0.005$ \\
\hline $\mathrm{CeO}_{2}$ & 0.04 & 0.055 \\
\hline $\mathrm{Cr}_{2} \mathrm{O}_{3}$ & 0.22 & 0.204 \\
\hline $\mathrm{Cs}_{2} \mathrm{O}$ & 0.14 & $\mathrm{NM}$ \\
\hline $\mathrm{Fe}_{2} \mathrm{O}_{3}$ & 16.09 & 16.4 \\
\hline $\mathrm{K}_{2} \mathrm{O}$ & 0.50 & 0.446 \\
\hline $\mathrm{La}_{2} \mathrm{O}_{3}$ & 0.15 & 0.146 \\
\hline $\mathrm{Li}_{2} \mathrm{O}$ & 0.50 & 0.465 \\
\hline $\mathrm{MgO}$ & 0.30 & 0.267 \\
\hline $\mathrm{MnO}$ & 6.09 & 3.78 \\
\hline $\mathrm{Na}_{2} \mathrm{O}$ & 11.48 & 12.9 \\
\hline $\mathrm{NiO}$ & 0.21 & 0.196 \\
\hline $\mathrm{P}_{2} \mathrm{O}_{5}$ & 0.21 & 0.224 \\
\hline $\mathrm{PbO}$ & 0.29 & 0.271 \\
\hline $\mathrm{SrO}$ & 10.09 & 8.41 \\
\hline $\mathrm{SiO}_{2}$ & 34.11 & 35.3 \\
\hline $\mathrm{TiO}_{2}$ & 0.06 & 0.057 \\
\hline $\mathrm{ZrO}_{2}$ & 0.16 & 0.158 \\
\hline
\end{tabular}

$\mathrm{NM}=$ not measured

A comparison between the measured and targeted compositions suggests that there were no significant problems in the batching or fabrication of this glass. Volatilization does not appear to an issue. It should be noted that the initial tests utilized a single batch to the melter and slurry feeding was not utilized.

\subsubsection{Homogeneity}

Representative samples from the "interior" and "exterior" regions were submitted for XRD analysis for an assessment of homogeneity / crystallization. Although visual observations suggested a potential significant difference in terms of the presence or absence of crystallization, XRD detected magnetite $\left(\mathrm{Fe}_{3} \mathrm{O}_{4}\right)$ and nepheline in both samples (see Figure 8-2 and Figure 8-3). In comparison, when the ICCM-2 glass was fabricated by US DOE participants (from reagent grade chemicals) only the CCC version contained both phases (see Appendix B, Figure B.3) - only magnetite was found in the quenched version (see Appendix B, Figure B.4). The presence of both crystalline phases in the exterior portion of the sample is perhaps a result of the thermal gradient that exists between the bulk glass (nominally at 1200 $1250^{\circ} \mathrm{C}$ ) and the cold wall. This thermal gradient would have existed throughout the initial test thus providing ample time for devitrification to occur. The presence of both phases in the interior or bulk portion of the monolith may have resulted from the slow cooling process within the melter. As was observed in the development of ICCM-2, the formation of nepheline did not necessarily have a negative impact on durability. 


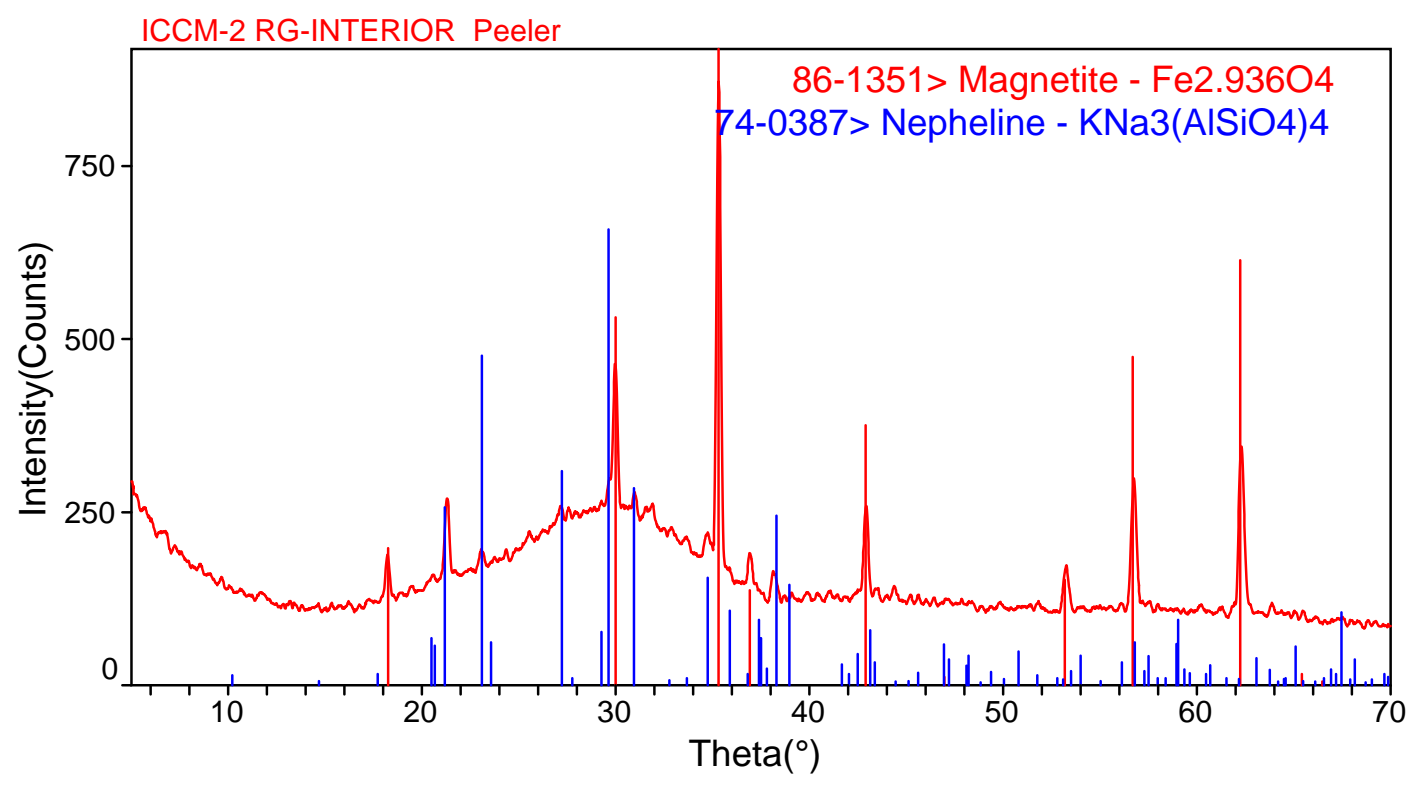

Figure 8-2. XRD Pattern of ICCM-2 Interior

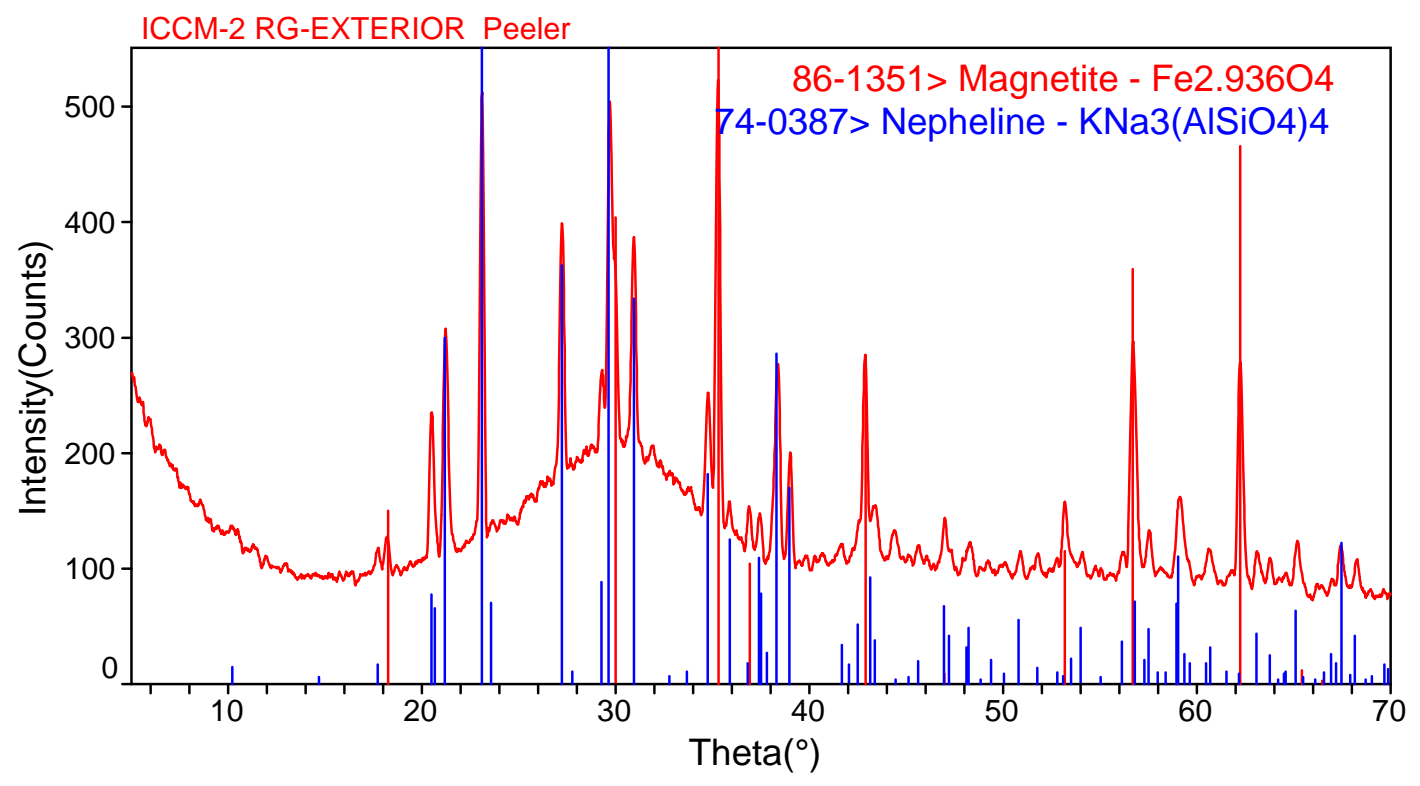

Figure 8-3. XRD Pattern of ICCM-2 Exterior 


\subsubsection{PCT}

To assess chemical durability, the PCT (ASTM 1998) was performed on both "interior" and "exterior" glass samples. The PCT was conducted in triplicate for each glass sample. Also included in this experimental test matrix were the EA glass (Jantzen et al. 1993), the Approved Reference Material (ARM-1) glass, and blanks. Samples were ground, washed, and prepared according to procedure. Fifteen (15) $\mathrm{mL}$ of Type I ASTM water were added to 1.5 grams of glass in stainless steel vessels. The vessels were closed, sealed, and placed in an oven at $90 \pm 2^{\circ} \mathrm{C}$. Samples were left at $90^{\circ} \mathrm{C} \pm 2{ }^{\circ} \mathrm{C}$ for 7 days. The resulting solutions (once cooled) were sampled (filtered and acidified), labeled, and analyzed.

Normalized release rates were calculated based on targeted compositions using the average of the logs of the leachate concentrations and are summarized in Table 8-2. Also shown in Table 8-2 are the normalized releases for the ICCM-2 glasses (quenched and CCC) made by U.S. investigators and the accepted EA values (Jantzen et al. 1993).

Table 8-2. Average Measured PCT Normalized Release (g/L)

\begin{tabular}{|c|c|c|c|c||}
\hline Glass & $\mathbf{r}_{\mathbf{B}}$ & $\mathbf{r}_{\mathbf{L i}}$ & $\mathbf{r}_{\mathbf{N a}}$ & $\mathbf{r}_{\mathbf{S i}}$ \\
\hline Interior & 0.105 & 0.189 & 0.262 & 0.071 \\
\hline Exterior & 0.094 & 0.188 & 0.256 & 0.070 \\
\hline ICCM-2 quenched & 0.060 & 0.040 & 0.238 & 0.060 \\
\hline ICCM-2 CCC & 0.158 & 0.060 & 0.190 & 0.051 \\
\hline EA & 8.35 & 4.78 & 6.67 & - \\
\hline
\end{tabular}

Glass durability as measured by the PCT for the interior and exterior samples was very similar to that measured for quenched and CCC ICCM-2 glass produced by US DOE participants. No significant differences were observed between any of these samples. Both the interior and exterior portions of the glass had $r_{i}$ values less than $0.3 \mathrm{~g} / \mathrm{m}^{2}$ - orders of magnitudes better than the EA glass for HLW. As observed during the development of ICCM-2, the formation of nepheline in the interior and exterior samples did not have an adverse impact on durability - a direct result of controlling the glass composition so that the expected residual glass composition would remain durable. Although the glass produced in the initial test yielded a durable product, potential processing issues led to the development of ICCM-14 and Aloy-3 as candidates for subsequent melter tests at KRI. 
Immobilization Technology Section

WSRC-TR-2002-00426

Savannah River Technology Center

Rev. 0

Westinghouse Savannah River Company

This page intentionally left blank. 


\subsection{References}

American Society for Testing and Materials (ASTM). 1990. "Standard Practice for Measuring Viscosity of Glass Above the Softening Point." ASTM C 965-81, in Annual Book of ASTM Standards, Vol. 15.02, Philadelphia, Pennsylvania.

American Society for Testing and Materials (ASTM). 1998. "Standard Test Method for Determining Chemical Durability of Nuclear Waste Glasses, The Product Consistency Test (PCT).” ASTM-C-128597, in Annual Book of ASTM Standards, Vol 12.01, Philadelphia, Pennsylvania.

Cicero CA, SL Marra, and MK Andrews. 1993. Phase Stability Determinations of DWPF Waste Glasses $(U)$, WSRC-TR-93-227, Westinghouse Savannah River Company, Aiken, SC.

Duff MC, DT Hobbs, and SD Fink. 2002. Permanganate Treatment Optimization Studies for Strontium and Actinide Removal from High Level Waste Simulants, WSRC-TR-2002-00027, Rev. 0, Westinghouse Savannah River Company, Aiken, SC.

Goles, RW, WC Buchmiller, and BD MacIsaac. 2002. Test Summary Report, Hanford C-106/AY-102 Vitrification Demonstration, PNNL-14603, Pacific Northwest National Laboratory, Richland, WA.

Herman, CC 2002a. Characterization of Glass Samples from Khlopin INEEL SBW Testing, SRT-GPD2002-00055, Revision 1, Westinghouse Savannah River Company, Aiken, South Carolina.

Herman, CC 2002b. Characterization of Glass Samples from Radon INEEL SBW Testing, SRT-GPD2002-00112, Westinghouse Savannah River Company, Aiken, South Carolina.

Herman, CC and DK Peeler. 2002. Characterization of Glass Samples from Khlopin Alkaline Surrogate June Testing, SRT-GPD-2002-00111, Westinghouse Savannah River Company, Aiken, South Carolina.

Herman, CC, DF Bickford, R Goles, D Gombert, and JG Richardson. 2002a. Run Plan: Cold Crucible Induction Melting of High Alkaline Surrogate at Khlopin Radium Institute, WSRC-RP-2002-00256, Westinghouse Savannah River Company, Aiken, South Carolina.

Herman, CC, DF Bickford, R Goles, and D Gombert. 2002b. Vitrification Demonstrations Run Plan: Vitrification Demonstration of DOE High Alkaline Surrogate in the Radon 200mm Crucible, WSRC-RP2002-00319, Westinghouse Savannah River Company, Aiken, South Carolina.

Hrma, P, GF Piepel, MJ Schweiger, DE Smith, D-S Kim, PE Redgate, JD Vienna, CA LoPresti, DB Simpson, DK Peeler, and MH Langowski. 1994. Property/Composition Relationships for Hanford HighLevel Waste Glasses Melting at $1150^{\circ} \mathrm{C}$, PNL-10359, Vol. 1 and 2, Pacific Northwest Laboratory, Richland, Washington.

Hrma, P and JD Vienna. 2003. Relationship Between Liquidus Temperature and Solubility, to be published in the proceedings of the Ceramic Transaction Series, International Symposium on Waste Management Technologies in Ceramic and Nuclear Industries. 
Immobilization Technology Section

WSRC-TR-2002-00426

Savannah River Technology Center

Rev. 0

Westinghouse Savannah River Company

Jantzen CM, and DF Bickford. 1985. Leaching of Devitrified Glass Containing Simulated SRP Nuclear Waste, Sci. Basis for Nuclear Waste Management, VIII, CM Jantzen, JA Stone and RC Ewing (eds.), Materials Research Society, Pittsburgh, PA 135-146.

Jantzen, CM, NE Bibler, DC Beam, CL Crawford, and MA Pickett. 1993. Characterization of the Defense Waste Processing Facility (DWPF) Environmental Assessment (EA) Glass Standard Reference Material (U), WSRC-TR-92-346, Revision 1, Westinghouse Savannah River Company, Aiken, South Carolina.

Kim, D-S, DK Peeler, and P Hrma. 1995. "Effects of Crystallization on the Chemical Durability of Nuclear Waste Glasses," Ceram. Trans. 61, 177-185.

Li, H, JD Vienna, PR Hrma, DE Smith, and MJ Schweiger. 1997. "Nepheline Precipitation in HighLevel Waste Glasses: Compositional Effects and Impact on the Waste Form Acceptability." In Scientific Basis for Nuclear Waste Management XX, Vol. 465, pp. 261-268. Materials Research Society, Pittsburgh, Pennsylvania.

Li, H, B Jones, P Hrma, and JD Vienna. 1998. "Compositional Effects on Liquidus Temperature of Hanford Simulated High-Level Waste Glasses Precipitating Nepheline $\left(\mathrm{NaAlSiO}_{4}\right)$," Ceram. Trans. 87, pp 279-288, American Ceramic Society, Westerville, Ohio.

Marra, SL, and CM Jantzen. 1993. Characterization of Projected DWPF Glasses Heat Treated to Simulate Canister Centerline Cooling (U), WSRC-TR-92-142, Rev. 1, Westinghouse Savannah River Company, Aiken, South Carolina.

Peeler, DK, TB Edwards, DR Best, IA Reamer, and RJ Workman. 2001. Hanford SPA Glasses: Fabrication, Characterization, and Chemical Analysis, WSRC-TR-2001-00570, Revision 0, Westinghouse Savannah River Company, Aiken, South Carolina.

Riley BJ, JA Rosario, and P Hrma. 2001. Impact of HLW Glass Crystallinity on the PCT Response, PNNL-13491, Pacific Northwest National Laboratory, Richland, WA.

Savannah River Technology Center (SRTC). 1999. "Determination of Glass Viscosity.” In: Glass Technology Manual L13.1, Technical Reference, GTOP-3-111, Rev. 0, Aiken, South Carolina.

Schumacher, RF and DK Peeler. 1998. Establishment of Harrop, High Temperature Viscometer (U), WSRC-RP-98-00737, Rev. 0, Westinghouse Savannah River Company, Aiken, South Carolina.

U.S. Department of Energy (DOE). 1996. Office of Environmental Management, Waste Acceptance Product Specifications for Vitrified High-Level Waste Forms, Rev. 2, DOE Document EM-WAPS, Germantown, Maryland. 
Immobilization Technology Section

WSRC-TR-2002-00426

Savannah River Technology Center

Rev. 0

Westinghouse Savannah River Company

\section{Appendix A}

\section{Target Versus Measured Chemical Composition Data}




\begin{tabular}{|c|c|c|c|c|c|c|c|c|}
\hline \multirow[b]{2}{*}{$\begin{array}{c}\text { WL (mass\%) } \\
\text { Oxide }\end{array}$} & \multicolumn{2}{|c|}{ ICCM-1 } & \multicolumn{2}{|c|}{ ICCM-2 } & \multicolumn{2}{|c|}{ ICCM-3 } & \multicolumn{2}{|c|}{ ICCM-4 } \\
\hline & \begin{tabular}{|c|}
60 \\
Target
\end{tabular} & Meas. & \begin{tabular}{|c|}
70 \\
Target
\end{tabular} & Meas. & \begin{tabular}{|c|}
60 \\
Target
\end{tabular} & Meas. & \begin{tabular}{|c|}
60 \\
Target
\end{tabular} & Meas. \\
\hline $\mathrm{Al}_{2} \mathrm{O}_{3}$ & 12.674 & 12.200 & \begin{tabular}{|l|}
14.787 \\
\end{tabular} & 15.100 & 12.674 & 12.400 & $\mid 12.674$ & 12.500 \\
\hline $\mathrm{B}_{2} \mathrm{O}_{3}$ & 5.000 & 5.250 & 3.000 & 3.250 & 3.415 & 3.610 & 3.000 & 3.120 \\
\hline $\mathrm{BaO}$ & 0.078 & 0.092 & 0.091 & 0.099 & 0.078 & 0.076 & 0.078 & \begin{tabular}{|l|}
0.079 \\
\end{tabular} \\
\hline $\mathrm{CaO}$ & 0.840 & 0.857 & 0.980 & 0.978 & 0.840 & 0.931 & 0.840 & \begin{tabular}{|l|}
0.919 \\
\end{tabular} \\
\hline $\mathrm{CdO}$ & 0.054 & 0.041 & 0.063 & $<0.005$ & 0.054 & 0.050 & 0.054 & \begin{tabular}{|l|l|} 
\\
\end{tabular} \\
\hline $\mathrm{CeO}_{2}$ & 0.036 & \begin{tabular}{|l|}
0.032 \\
\end{tabular} & 0.042 & \begin{tabular}{|l|}
0.033 \\
\end{tabular} & 0.036 & \begin{tabular}{|l|l|}
0.046 \\
\end{tabular} & 0.036 & \begin{tabular}{|l|l|}
0.046 \\
\end{tabular} \\
\hline $\mathrm{Cr}_{2} \mathrm{O}_{3}$ & 0.192 & \begin{tabular}{|l|}
0.159 \\
\end{tabular} & 0.224 & 0.206 & \begin{tabular}{|l|l|}
0.192 \\
\end{tabular} & \begin{tabular}{|l|l|}
0.200 \\
\end{tabular} & 0.192 & \begin{tabular}{|l|l|}
0.193 \\
\end{tabular} \\
\hline $\mathrm{Fe}_{2} \mathrm{O}_{3}$ & 13.790 & 14.000 & 16.088 & 16.100 & 13.790 & 14.000 & 13.790 & 14.200 \\
\hline $\mathrm{K}_{2} \mathrm{O}$ & 2.959 & 2.920 & 0.500 & 0.424 & 6.000 & 5.360 & 4.276 & \begin{tabular}{|l|l|}
4.050 \\
\end{tabular} \\
\hline $\mathrm{La}_{2} \mathrm{O}_{3}$ & 0.132 & 0.125 & 0.154 & 0.136 & 0.132 & \begin{tabular}{|l|l|}
0.120 \\
\end{tabular} & 0.132 & \begin{tabular}{|l|l|}
0.122 \\
\end{tabular} \\
\hline $\mathrm{Li}_{2} \mathrm{O}$ & 1.697 & 1.580 & 0.500 & 0.473 & 0.505 & \begin{tabular}{|l|}
0.527 \\
\end{tabular} & \begin{tabular}{|l|l|}
1.199 \\
\end{tabular} & \begin{tabular}{|l|}
1.150 \\
\end{tabular} \\
\hline $\mathrm{MgO}$ & 0.258 & 0.234 & 0.301 & 0.256 & 0.258 & 0.229 & 0.258 & 0.229 \\
\hline $\mathrm{MnO}$ & 5.218 & 5.710 & 6.088 & 6.270 & 5.218 & 5.010 & \begin{tabular}{|l|l|}
5.218 \\
\end{tabular} & \begin{tabular}{|l|l|}
5.040 \\
\end{tabular} \\
\hline $\mathrm{Na}_{2} \mathrm{O}$ & 10.047 & 10.000 & $|11.477|$ & 12.200 & 16.875 & 16.900 & 17.000 & $\mid 17.700$ \\
\hline $\mathrm{NiO}$ & 0.180 & 0.172 & 0.210 & 0.178 & \begin{tabular}{|l|l|}
0.180 \\
\end{tabular} & \begin{tabular}{|l|l|}
0.169 \\
\end{tabular} & 0.180 & \begin{tabular}{|l|l|}
0.167 \\
\end{tabular} \\
\hline $\mathrm{P}_{2} \mathrm{O}_{5}$ & 0.180 & 0.836 & 0.210 & 0.238 & \begin{tabular}{|l|l|}
0.180 \\
\end{tabular} & \begin{tabular}{|l|l|}
0.180 \\
\end{tabular} & 1.500 & \begin{tabular}{|l|}
1.450 \\
\end{tabular} \\
\hline $\mathrm{PbO}$ & 0.252 & \begin{tabular}{|l|}
0.025 \\
\end{tabular} & 0.294 & $\mathrm{NM}$ & 0.252 & \begin{tabular}{|l|}
0.249 \\
\end{tabular} & 0.252 & \begin{tabular}{|l|l|}
0.253 \\
\end{tabular} \\
\hline $\mathrm{PdO}$ & 0.006 & NM & 0.007 & NM & 0.006 & $<0.100$ & 0.006 & $<0.100$ \\
\hline $\mathrm{SO}_{3}$ & 0.030 & NM & 0.035 & NM & 0.030 & \begin{tabular}{|l|}
0.097 \\
\end{tabular} & \begin{tabular}{l|l|}
0.030 \\
\end{tabular} & \begin{tabular}{|l|}
0.084 \\
\end{tabular} \\
\hline $\mathrm{SiO}_{2}$ & 37.092 & 37.000 & 34.118 & 34.700 & 30.000 & 29.900 & 30.000 & 29.800 \\
\hline $\mathrm{SrO}$ & 8.643 & \begin{tabular}{|l|l|}
8.370 \\
\end{tabular} & \begin{tabular}{|l|}
10.084 \\
\end{tabular} & 10.300 & 8.643 & 7.490 & 8.643 & \begin{tabular}{|l|l|}
7.450 \\
\end{tabular} \\
\hline $\mathrm{TiO}_{2}$ & 0.048 & 0.038 & 0.056 & 0.045 & 0.048 & 0.031 & 0.048 & 0.032 \\
\hline $\mathrm{ZrO}_{2}$ & 0.138 & 0.150 & 0.161 & \begin{tabular}{|l|l|}
0.184 \\
\end{tabular} & 0.138 & \begin{tabular}{|l|l|}
0.130 \\
\end{tabular} & 0.138 & \begin{tabular}{|l|l|}
0.037 \\
\end{tabular} \\
\hline Total & 100.00 & \begin{tabular}{|l|}
99.70 \\
\end{tabular} & 100.00 & 101.00 & 100.00 & 97.80 & 100.00 & \begin{tabular}{|l|}
98.70 \\
\end{tabular} \\
\hline
\end{tabular}




\begin{tabular}{|c|c|c|c|c|c|c|c|c|}
\hline \multirow[b]{2}{*}{$\begin{array}{c}\text { WL (mass\%) } \\
\text { Oxide }\end{array}$} & \multicolumn{2}{|c|}{ ICCM-5 } & \multicolumn{2}{|c|}{ ICCM-6 } & \multicolumn{2}{|c|}{ ICCM-7 } & \multicolumn{2}{|c|}{ ICCM-8 } \\
\hline & \begin{tabular}{|c|}
59 \\
Target
\end{tabular} & Meas. & \begin{tabular}{|c|}
55 \\
Target
\end{tabular} & Meas. & \begin{tabular}{|c|}
60 \\
Target
\end{tabular} & Meas. & \begin{tabular}{|c|}
55 \\
Target
\end{tabular} & Meas. \\
\hline $\mathrm{Al}_{2} \mathrm{O}_{3}$ & 12.463 & 12.300 & 11.618 & 11.200 & 12.674 & 12.200 & 11.618 & 11.200 \\
\hline $\mathrm{B}_{2} \mathrm{O}_{3}$ & 3.000 & 3.190 & 4.000 & 4.090 & 3.000 & 3.040 & 3.000 & \begin{tabular}{|l|}
2.980 \\
\end{tabular} \\
\hline $\mathrm{BaO}$ & \begin{tabular}{|l|l|}
0.077 \\
\end{tabular} & 0.076 & 0.071 & 0.081 & \begin{tabular}{|l|l|}
0.078 \\
\end{tabular} & 0.086 & \begin{tabular}{|l|}
0.071 \\
\end{tabular} & \begin{tabular}{|l|l|}
0.088 \\
\end{tabular} \\
\hline $\mathrm{CaO}$ & \begin{tabular}{|l|}
0.826 \\
\end{tabular} & 0.902 & 0.770 & 0.818 & 0.840 & \begin{tabular}{|l|}
0.771 \\
\end{tabular} & \begin{tabular}{|l|l|}
0.770 \\
\end{tabular} & \begin{tabular}{|l|l|}
0.771 \\
\end{tabular} \\
\hline $\mathrm{CdO}$ & \begin{tabular}{|l|l|}
0.053 \\
\end{tabular} & 0.046 & 0.049 & 0.038 & 0.054 & 0.042 & \begin{tabular}{|l|}
0.049 \\
\end{tabular} & \begin{tabular}{|l|l|}
0.040 \\
\end{tabular} \\
\hline $\mathrm{CeO}_{2}$ & \begin{tabular}{|l|l|}
0.035 \\
\end{tabular} & 0.045 & 0.033 & 0.031 & 0.036 & 0.028 & 0.033 & 0.032 \\
\hline $\mathrm{Cr}_{2} \mathrm{O}_{3}$ & \begin{tabular}{|l|l|}
0.189 \\
\end{tabular} & 0.191 & 0.176 & \begin{tabular}{|l|l|l|}
0.178 \\
\end{tabular} & 0.192 & \begin{tabular}{|l|l|}
0.193 \\
\end{tabular} & \begin{tabular}{|l|l|}
0.176 \\
\end{tabular} & \begin{tabular}{|l|}
0.181 \\
\end{tabular} \\
\hline $\mathrm{Fe}_{2} \mathrm{O}_{3}$ & 13.560 & 13.800 & 12.641 & 13.000 & 13.790 & 14.000 & 12.641 & 12.800 \\
\hline $\mathrm{K}_{2} \mathrm{O}$ & \begin{tabular}{|l|l|}
0.744 \\
\end{tabular} & 0.808 & 0.027 & $<0.100$ & 0.030 & $<0.100$ & \begin{tabular}{|l|l|}
0.027 \\
\end{tabular} & $<0.100$ \\
\hline $\mathrm{La}_{2} \mathrm{O}_{3}$ & \begin{tabular}{|l|l}
0.130 \\
\end{tabular} & 0.118 & 0.121 & 0.110 & 0.132 & \begin{tabular}{|l|l|}
0.122 \\
\end{tabular} & \begin{tabular}{|l|}
0.121 \\
\end{tabular} & \begin{tabular}{|l|}
0.105 \\
\end{tabular} \\
\hline $\mathrm{Li}_{2} \mathrm{O}$ & \begin{tabular}{|l|l|}
1.164 \\
\end{tabular} & 1.140 & 2.363 & 2.190 & 0.500 & 0.516 & \begin{tabular}{|l|l|}
1.574 \\
\end{tabular} & 1.480 \\
\hline $\mathrm{MgO}$ & \begin{tabular}{|l|l|} 
& 0.254 \\
\end{tabular} & 0.216 & 0.236 & 0.200 & 0.258 & 0.221 & 0.236 & 0.204 \\
\hline $\mathrm{MnO}$ & \begin{tabular}{|l|l|}
5.131 \\
\end{tabular} & \begin{tabular}{|l|l|}
4.860 \\
\end{tabular} & 4.784 & 5.160 & \begin{tabular}{|l|l|}
5.218 \\
\end{tabular} & \begin{tabular}{|l|l|}
5.560 \\
\end{tabular} & \begin{tabular}{|l|l|}
4.784 \\
\end{tabular} & \begin{tabular}{|l|l|}
5.130 \\
\end{tabular} \\
\hline $\mathrm{Na}_{2} \mathrm{O}$ & 19.918 & 20.700 & 19.500 & 19.000 & 21.837 & 20.900 & 21.289 & 21.600 \\
\hline $\mathrm{NiO}$ & \begin{tabular}{|l|l|}
0.177 \\
\end{tabular} & \begin{tabular}{|l|}
0.165 \\
\end{tabular} & 0.165 & \begin{tabular}{|l|l|}
0.149 \\
\end{tabular} & 0.180 & \begin{tabular}{|l|l|}
0.157 \\
\end{tabular} & \begin{tabular}{|l|l|}
0.165 \\
\end{tabular} & \begin{tabular}{|l|l|}
0.151 \\
\end{tabular} \\
\hline $\mathrm{P}_{2} \mathrm{O}_{5}$ & 1.750 & 1.660 & 1.250 & 1.210 & 1.500 & 1.400 & 0.165 & 0.204 \\
\hline $\mathrm{PbO}$ & \begin{tabular}{|l|l|}
0.248 \\
\end{tabular} & 0.242 & 0.231 & 0.208 & 0.252 & 0.227 & 0.231 & 0.207 \\
\hline $\mathrm{PdO}$ & \begin{tabular}{|l|l|}
0.006 \\
\end{tabular} & $\mid<0.100$ & 0.005 & NM & 0.006 & NM & 0.005 & NM \\
\hline $\mathrm{SO}_{3}$ & \begin{tabular}{|l|l|}
0.029 \\
\end{tabular} & \begin{tabular}{|l|l|}
0.079 \\
\end{tabular} & 0.027 & $\mathrm{NM}$ & 0.030 & $\mathrm{NM}$ & \begin{tabular}{|l|l|}
0.027 \\
\end{tabular} & $\mathrm{NM}$ \\
\hline $\mathrm{SiO}_{2}$ & 31.117 & 31.100 & 33.420 & 32.900 & 30.108 & 29.700 & 34.505 & 32.100 \\
\hline $\mathrm{SrO}$ & \begin{tabular}{|l|l|}
8.499 \\
\end{tabular} & 7.380 & 7.923 & \begin{tabular}{|l|}
7.740 \\
\end{tabular} & 8.643 & \begin{tabular}{|l|}
8.160 \\
\end{tabular} & \begin{tabular}{|l|}
7.923 \\
\end{tabular} & \begin{tabular}{|l|l|}
7.170 \\
\end{tabular} \\
\hline $\mathrm{TiO}_{2}$ & \begin{tabular}{|l|l|}
0.047 \\
\end{tabular} & \begin{tabular}{|l|l|}
0.029 \\
\end{tabular} & 0.044 & 0.030 & \begin{tabular}{|l|l|}
0.048 \\
\end{tabular} & 0.033 & \begin{tabular}{|l|l|}
0.044 \\
\end{tabular} & \begin{tabular}{|l|l|}
0.030 \\
\end{tabular} \\
\hline $\mathrm{ZrO}_{2}$ & 0.136 & 0.025 & 0.126 & 0.104 & 0.138 & 0.077 & 0.126 & 0.134 \\
\hline Total & 100.00 & 99.20 & 100.00 & 98.40 & 100.00 & 97.40 & 100.00 & 96.70 \\
\hline
\end{tabular}




\begin{tabular}{|c|c|c|c|c|c|c|c|c|}
\hline \multirow[b]{2}{*}{$\begin{array}{c}\text { WL (mass \%) } \\
\text { Oxide }\end{array}$} & \multicolumn{2}{|c|}{ ICCM-9 } & \multicolumn{2}{|c|}{ ICCM-10 } & \multicolumn{2}{|c|}{ ICCM-11 } & \multicolumn{2}{|c|}{ ICCM-12 } \\
\hline & \begin{tabular}{|c|}
60 \\
Target
\end{tabular} & Meas. & \begin{tabular}{|c|}
60 \\
Target
\end{tabular} & Meas. & $\begin{array}{c}\mathbf{6 0} \\
\text { Target }\end{array}$ & Meas. & \begin{tabular}{|c|}
60 \\
Target
\end{tabular} & Meas. \\
\hline $\mathrm{Al}_{2} \mathrm{O}_{3}$ & 12.674 & 12.100 & 12.674 & 12.100 & 12.674 & 12.300 & 12.674 & 12.300 \\
\hline $\mathrm{B}_{2} \mathrm{O}_{3}$ & 3.000 & 2.960 & 4.000 & 3.930 & 6.905 & 6.890 & 6.000 & 6.020 \\
\hline $\mathrm{BaO}$ & \begin{tabular}{|l|}
0.078 \\
\end{tabular} & 0.089 & 0.078 & 0.089 & 0.078 & 0.092 & 0.078 & 0.221 \\
\hline $\mathrm{CaO}$ & \begin{tabular}{|l|}
0.840 \\
\end{tabular} & 0.832 & 0.840 & 0.837 & 0.840 & 0.847 & 0.840 & \begin{tabular}{|l|l|}
0.847 \\
\end{tabular} \\
\hline $\mathrm{CdO}$ & \begin{tabular}{|l|l|}
0.054 \\
\end{tabular} & 0.044 & 0.054 & 0.044 & 0.054 & 0.044 & 0.054 & \begin{tabular}{|l|l|}
0.047 \\
\end{tabular} \\
\hline $\mathrm{CeO}_{2}$ & \begin{tabular}{|l|l|}
0.036 \\
\end{tabular} & 0.032 & 0.036 & 0.029 & 0.036 & 0.031 & 0.036 & 0.030 \\
\hline $\mathrm{Cr}_{2} \mathrm{O}_{3}$ & \begin{tabular}{|l|l|}
0.192 \\
\end{tabular} & \begin{tabular}{|l|l|}
0.197 \\
\end{tabular} & 0.192 & 0.200 & 0.192 & \begin{tabular}{|l|l|}
0.194 \\
\end{tabular} & 0.192 & 0.204 \\
\hline $\mathrm{Fe}_{2} \mathrm{O}_{3}$ & 13.790 & 14.000 & 13.790 & 14.000 & 13.790 & 14.600 & 13.790 & 14.200 \\
\hline $\mathrm{K}_{2} \mathrm{O}$ & \begin{tabular}{|l|l|}
0.003 \\
\end{tabular} & $<0.100$ & 0.030 & $<0.100$ & 5.252 & 4.880 & 6.000 & 5.410 \\
\hline $\mathrm{La}_{2} \mathrm{O}_{3}$ & \begin{tabular}{|l|l|}
0.132 \\
\end{tabular} & 0.122 & 0.132 & 0.122 & 0.132 & 0.129 & 0.132 & 0.128 \\
\hline $\mathrm{Li}_{2} \mathrm{O}$ & \begin{tabular}{|l|l|}
0.000 \\
\end{tabular} & 0.101 & 0.000 & 0.101 & 1.034 & 0.991 & 0.533 & 0.531 \\
\hline $\mathrm{MgO}$ & 0.258 & 0.224 & 0.258 & 0.220 & 0.258 & 0.222 & 0.258 & 0.222 \\
\hline $\mathrm{MnO}$ & 5.218 & 5.570 & 5.218 & 5.570 & 5.218 & 5.530 & 5.218 & 5.710 \\
\hline $\mathrm{Na}_{2} \mathrm{O}$ & 22.850 & 23.100 & 22.664 & 20.800 & 9.837 & 9.260 & 11.239 & 11.000 \\
\hline $\mathrm{NiO}$ & \begin{tabular}{|l|}
0.180 \\
\end{tabular} & 0.163 & 0.180 & 0.164 & 0.180 & 0.165 & 0.180 & 0.166 \\
\hline $\mathrm{P}_{2} \mathrm{O}_{5}$ & \begin{tabular}{|l|l|}
0.180 \\
\end{tabular} & 0.208 & 0.180 & 0.208 & 0.180 & 0.208 & 0.180 & 0.210 \\
\hline $\mathrm{PbO}$ & 0.252 & 0.226 & 0.252 & 0.232 & 0.252 & 0.235 & 0.252 & 0.238 \\
\hline $\mathrm{PdO}$ & 0.006 & NM & 0.006 & $\mathrm{NM}$ & 0.006 & $\mathrm{NM}$ & 0.006 & NM \\
\hline $\mathrm{SO}_{3}$ & \begin{tabular}{|l|l|}
0.030 \\
\end{tabular} & NM & 0.030 & NM & 0.030 & NM & 0.030 & NM \\
\hline $\mathrm{SiO}_{2}$ & 30.915 & 29.700 & 30.101 & 29.700 & 33.767 & 32.300 & 33.023 & 32.700 \\
\hline $\mathrm{SrO}$ & 8.643 & 7.920 & 8.643 & 8.050 & 8.643 & 7.990 & 8.643 & 7.920 \\
\hline $\mathrm{TiO}_{2}$ & \begin{tabular}{|l|l|}
0.048 \\
\end{tabular} & 0.033 & 0.048 & 0.033 & 0.048 & 0.034 & 0.048 & 0.033 \\
\hline $\mathrm{ZrO}_{2}$ & \begin{tabular}{|l|l|}
0.138 \\
\end{tabular} & 0.140 & 0.138 & 0.138 & 0.138 & 0.138 & 0.138 & 0.138 \\
\hline Total & 100.00 & 97.800 & 100.00 & 96.30 & 100.00 & 97.10 & 100.00 & 98.30 \\
\hline
\end{tabular}




\begin{tabular}{|c|c|c|c|c|c|c|}
\hline \multirow[b]{2}{*}{$\begin{array}{l}\text { WL } \\
(\text { mass \%) } \\
\text { Oxide }\end{array}$} & \multicolumn{2}{|c|}{ ICCM-13 } & \multicolumn{2}{|c|}{ ICCM-14 } & \multicolumn{2}{|c|}{ Aloy-3 } \\
\hline & $\begin{array}{c}60 \\
\text { Target }\end{array}$ & Meas. & $\begin{array}{c}\mathbf{7 0} \\
\text { Target }\end{array}$ & Meas. & $\begin{array}{c}70 \\
\text { Target }\end{array}$ & Meas. \\
\hline $\mathrm{Al}_{2} \mathrm{O}_{3}$ & 12.674 & 12.400 & 14.79 & 14.4 & 14.79 & 14.9 \\
\hline $\mathrm{B}_{2} \mathrm{O}_{3}$ & 12.080 & 12.100 & 2.50 & 2.47 & 4.0 & 3.96 \\
\hline $\mathrm{BaO}$ & 0.078 & \begin{tabular}{|l|}
0.216 \\
\end{tabular} & 0.09 & $<0.01$ & 0.09 & $<0.01$ \\
\hline $\mathrm{CaO}$ & 0.840 & 0.829 & 0.98 & 1.04 & 0.98 & 1.06 \\
\hline $\mathrm{CdO}$ & 0.054 & 0.048 & 0.06 & 0.028 & 0.06 & 0.032 \\
\hline $\mathrm{CeO}_{2}$ & 0.036 & \begin{tabular}{|l|}
0.032 \\
\end{tabular} & \multicolumn{2}{|c|}{\begin{tabular}{l|l}
0.036 & $\mathrm{NM}$ \\
\end{tabular}} & \multicolumn{2}{|c|}{\begin{tabular}{l|l|l}
0.036 & $\mathrm{NM}$ \\
\end{tabular}} \\
\hline $\mathrm{Cr}_{2} \mathrm{O}_{3}$ & 0.192 & 0.184 & 0.22 & 0.170 & 0.22 & 0.160 \\
\hline $\mathrm{Fe}_{2} \mathrm{O}_{3}$ & 13.790 & 14.300 & 16.09 & 16.40 & 16.09 & 15.9 \\
\hline $\mathrm{K}_{2} \mathrm{O}$ & 0.030 & $<0.100$ & 0.03 & $<0.01$ & 0.03 & $<0.01$ \\
\hline $\mathrm{La}_{2} \mathrm{O}_{3}$ & 0.132 & 0.127 & 0.15 & 0.132 & 0.15 & 0.131 \\
\hline $\mathrm{Li}_{2} \mathrm{O}$ & 1.081 & 1.030 & 2.00 & 1.98 & 2.00 & 1.74 \\
\hline $\mathrm{MgO}$ & 0.258 & \begin{tabular}{|l|}
0.209 \\
\end{tabular} & 0.30 & 0.230 & 0.30 & 0.222 \\
\hline $\mathrm{MnO}$ & 5.218 & 5.710 & 6.09 & 5.88 & 6.09 & 5.95 \\
\hline $\mathrm{Na}_{2} \mathrm{O}$ & 9.837 & \begin{tabular}{|l|}
9.760 \\
\end{tabular} & 11.48 & 12.4 & 11.48 & 12.5 \\
\hline $\mathrm{NiO}$ & 0.180 & 0.158 & 0.21 & 0.168 & 0.21 & 0.147 \\
\hline $\mathrm{P}_{2} \mathrm{O}_{5}$ & 0.180 & \begin{tabular}{|l|}
0.210 \\
\end{tabular} & 0.21 & NM & 0.21 & NM \\
\hline $\mathrm{PbO}$ & 0.252 & 0.226 & 0.29 & 0.261 & 0.29 & 0.250 \\
\hline $\mathrm{PdO}$ & 0.006 & NM & 0.01 & $<0.01$ & 0.01 & $<0.01$ \\
\hline $\mathrm{SO}_{3}$ & 0.030 & $\mathrm{NM}$ & 0.03 & NM & 0.03 & $\mathrm{NM}$ \\
\hline $\mathrm{SiO}_{2}$ & 33.767 & 33.600 & 33.59 & 34.4 & 32.08 & 32.3 \\
\hline $\mathrm{SrO}$ & 8.643 & 7.920 & 10.08 & 10.2 & 10.08 & 10.6 \\
\hline $\mathrm{TiO}_{2}$ & 0.048 & 0.030 & 0.06 & 0.053 & 0.06 & 0.050 \\
\hline $\mathrm{ZrO}_{2}$ & 0.138 & 0.126 & 0.16 & 0.144 & 0.16 & 0.139 \\
\hline Total & 100.00 & 99.20 & 100.00 & 100.00 & 100.00 & 100.00 \\
\hline
\end{tabular}


Immobilization Technology Section

WSRC-TR-2002-00426

Savannah River Technology Center

Rev. 0

Westinghouse Savannah River Company

This page intentionally left blank. 
Immobilization Technology Section

WSRC-TR-2002-00426

Savannah River Technology Center

Rev. 0

Westinghouse Savannah River Company

\section{Appendix B}

\section{XRD Results for ICCM Glasses as a Function of Heat Treatment}




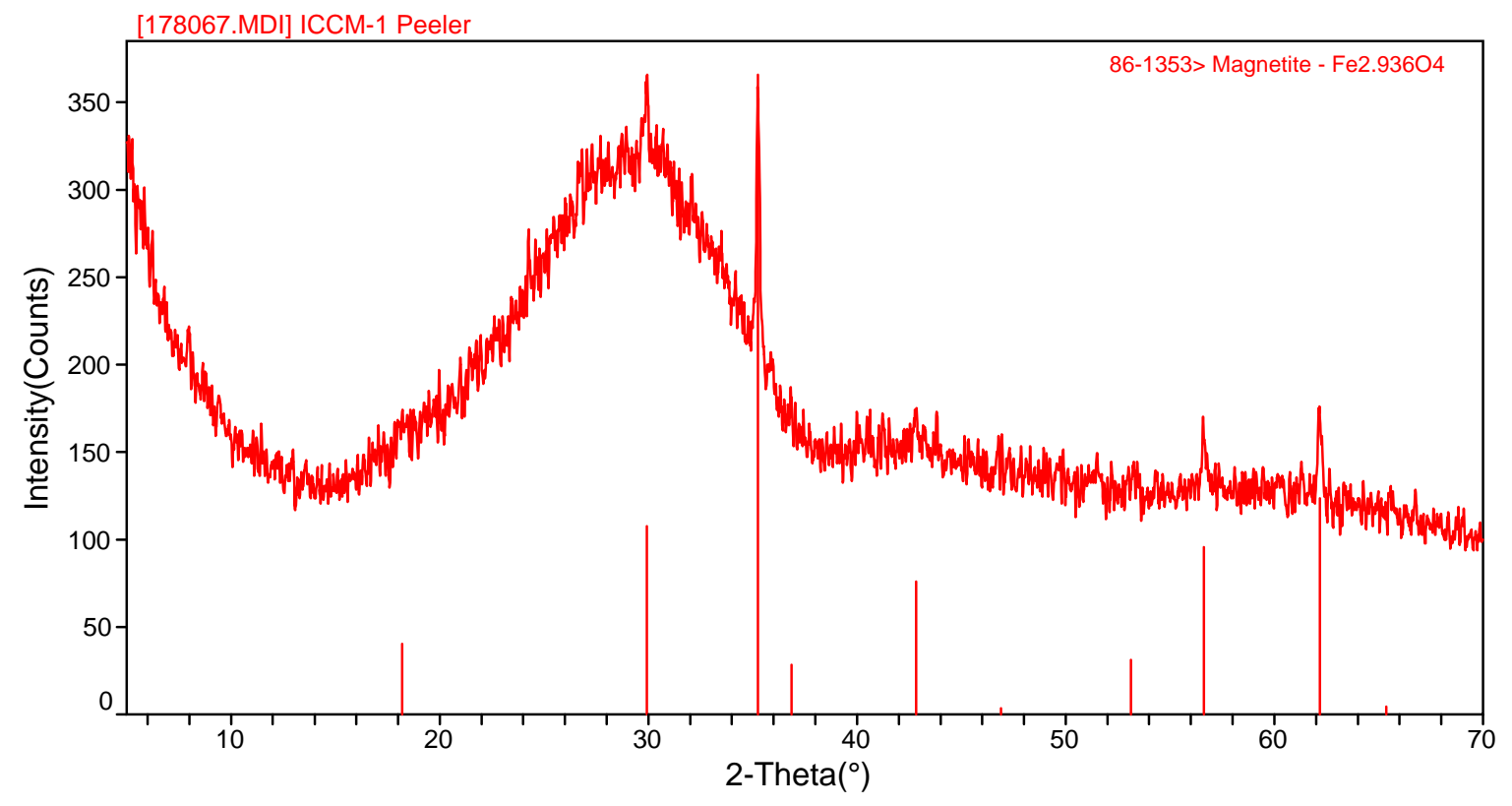

Figure B.1. XRD Results of ICCM-1 Quenched.

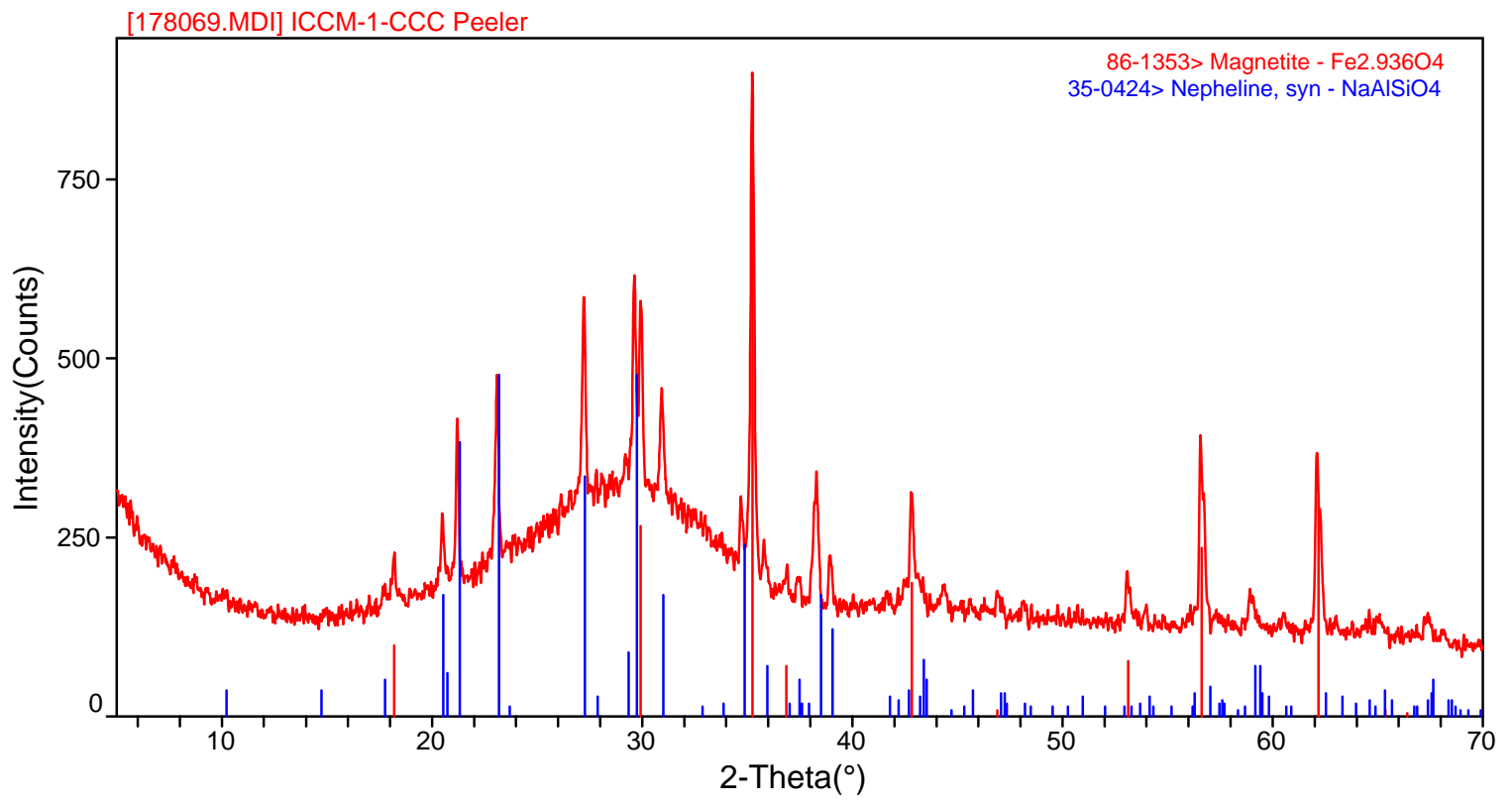

Figure B.2. XRD Results of ICCM-1 CCC. 


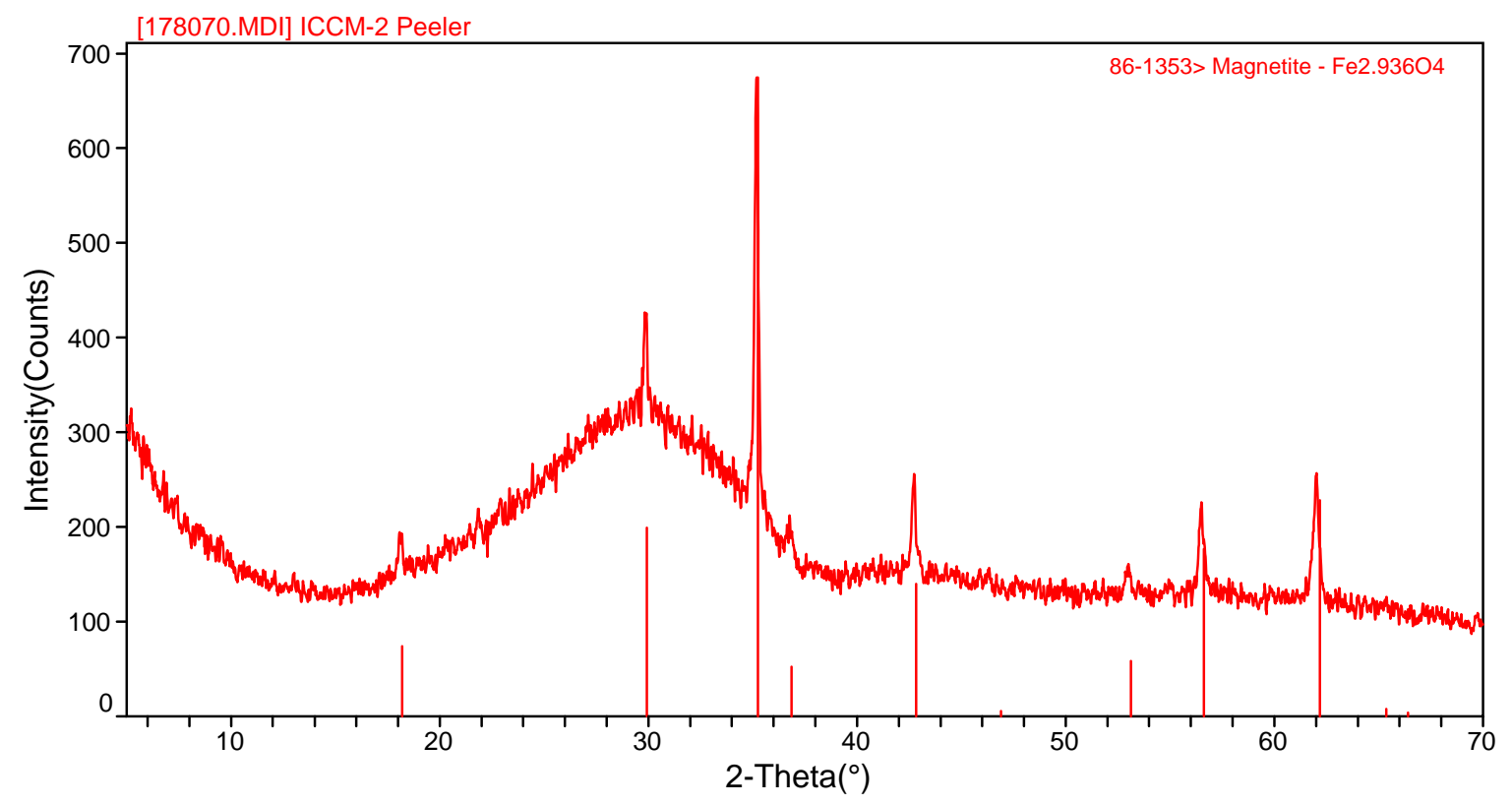

Figure B.3. XRD Results of ICCM-2 Quenched.

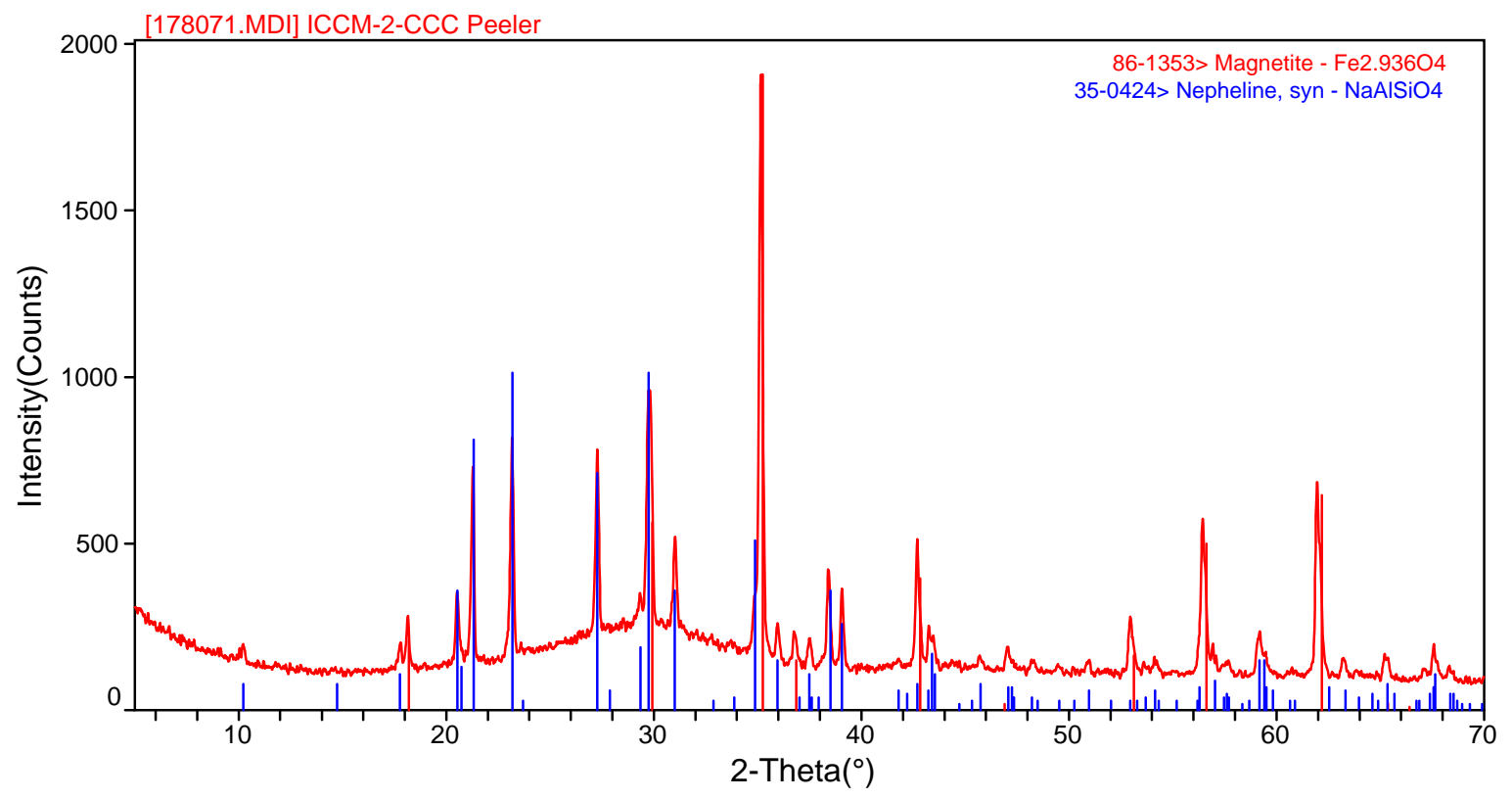

Figure B.4. XRD Results of ICCM-2 CCC. 


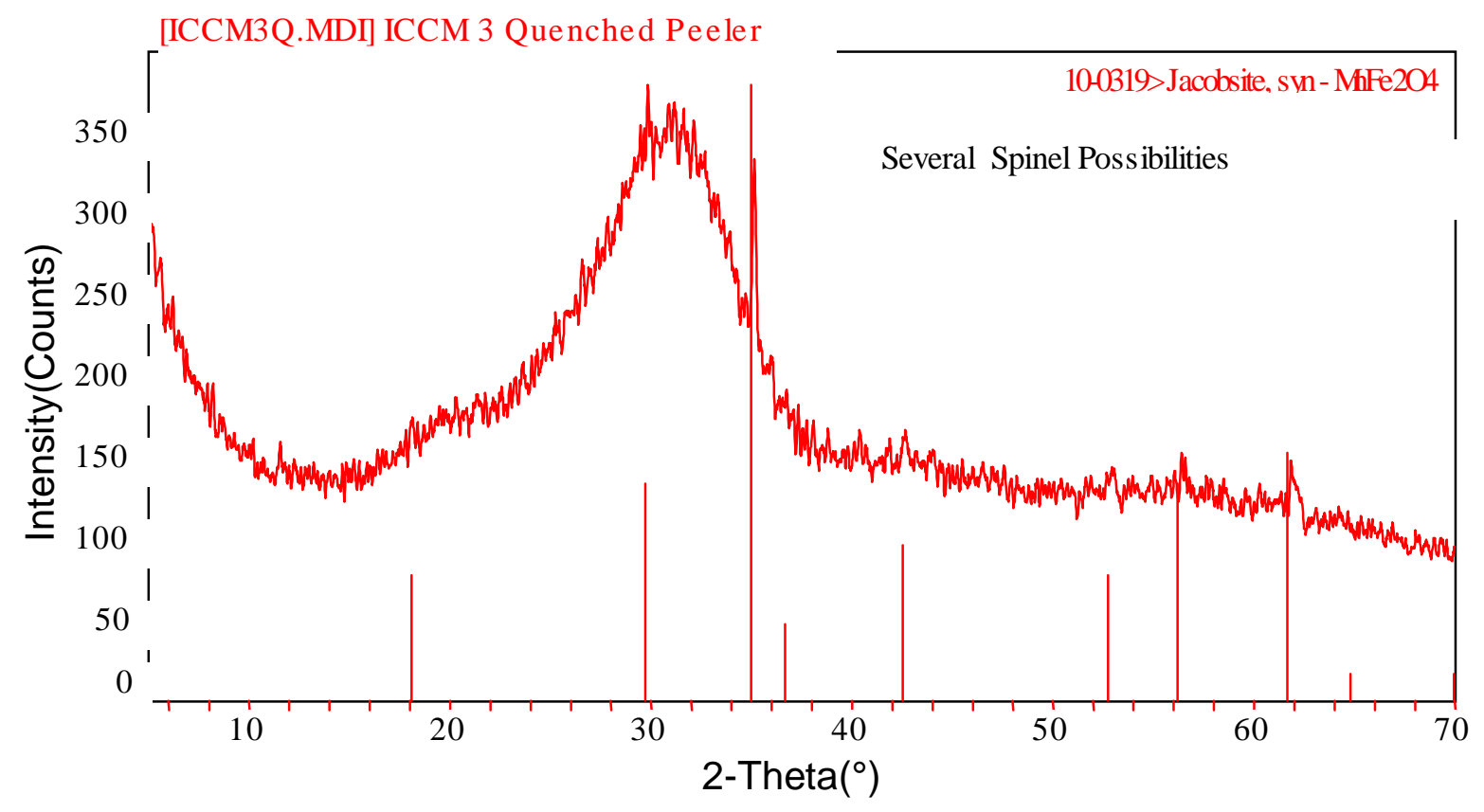

Figure B.5. XRD Results of ICCM-3 Quenched.

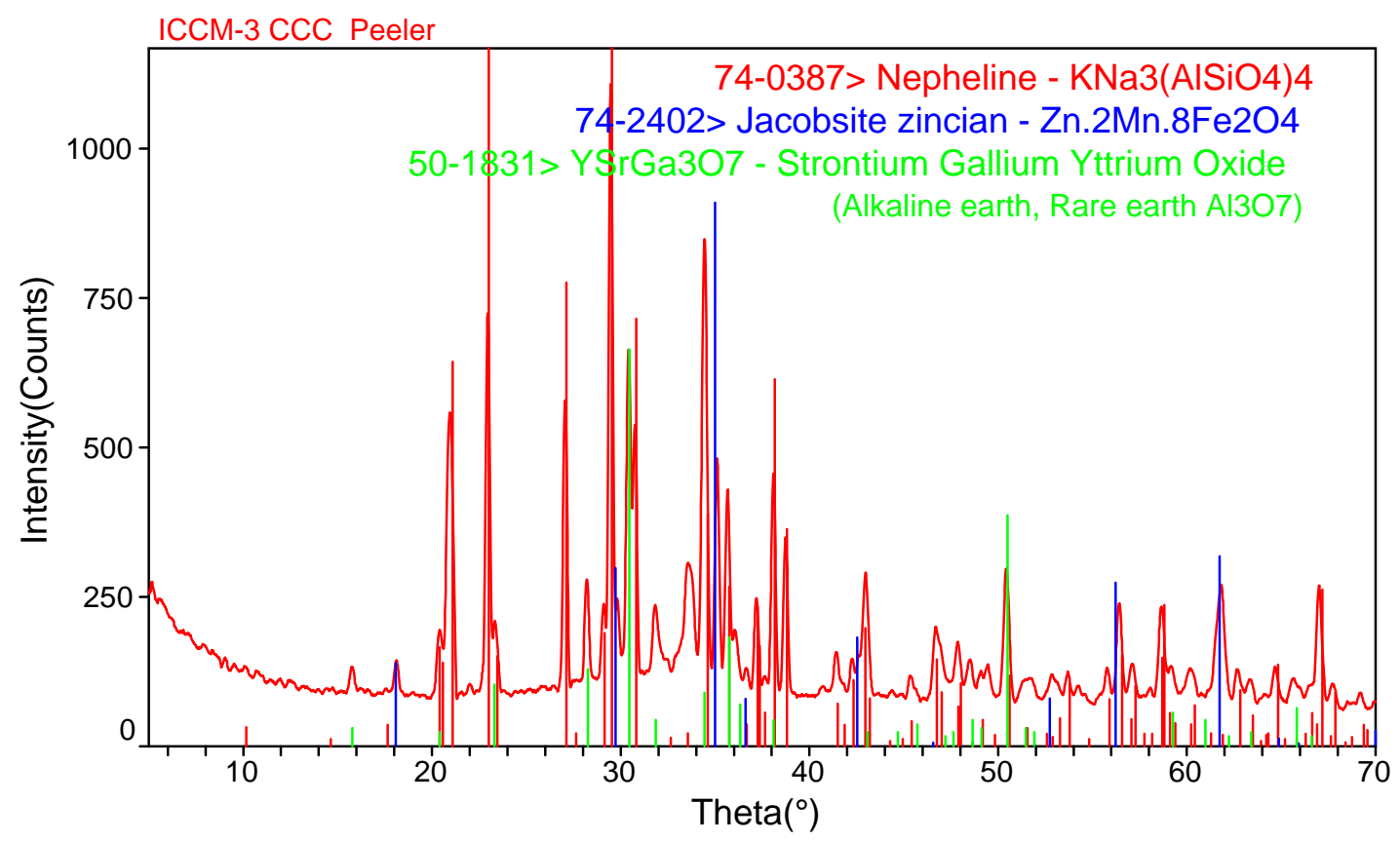

Figure B.6. XRD Results of ICCM-3 CCC. 


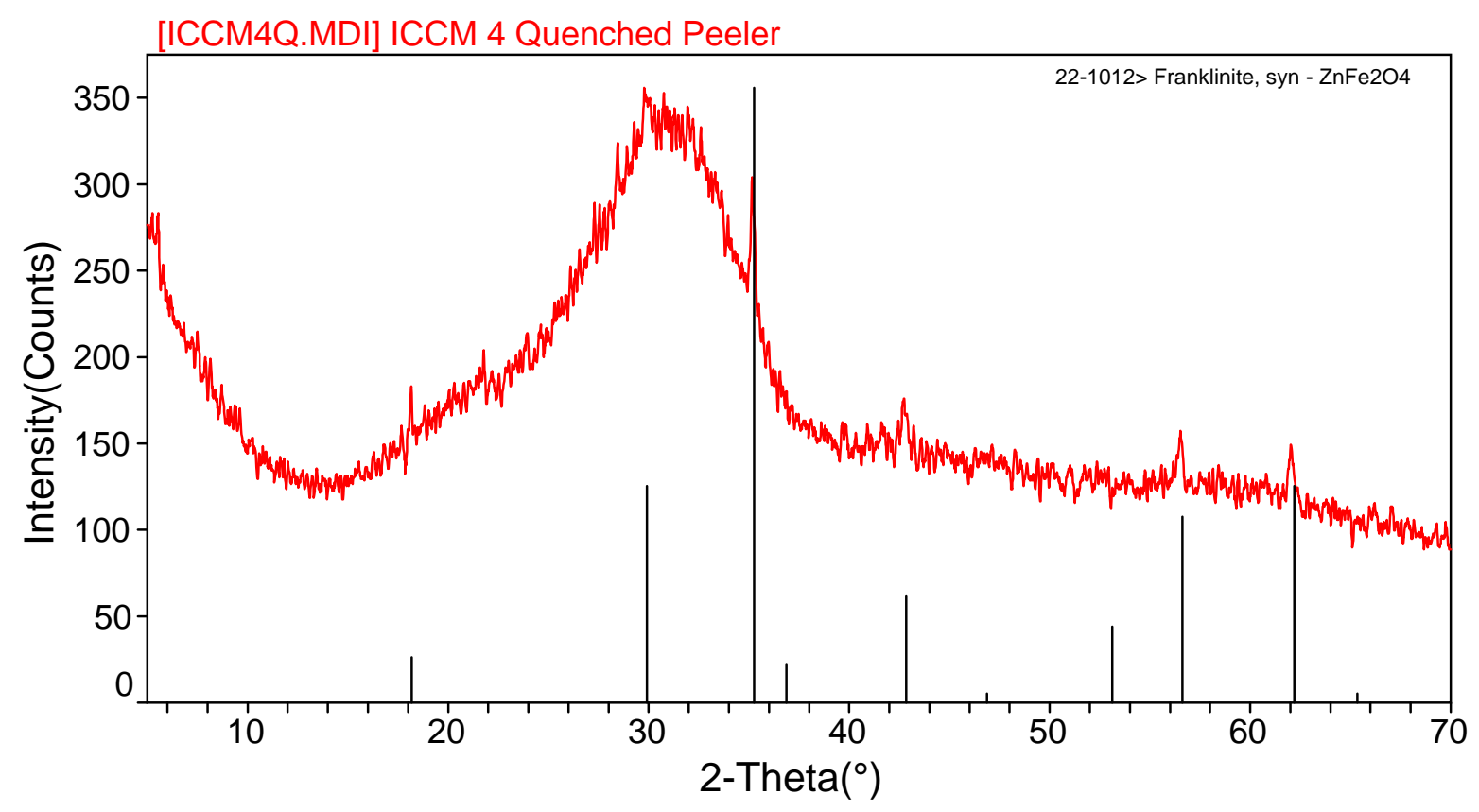

Figure B.7. XRD Results of ICCM-4 Quenched.

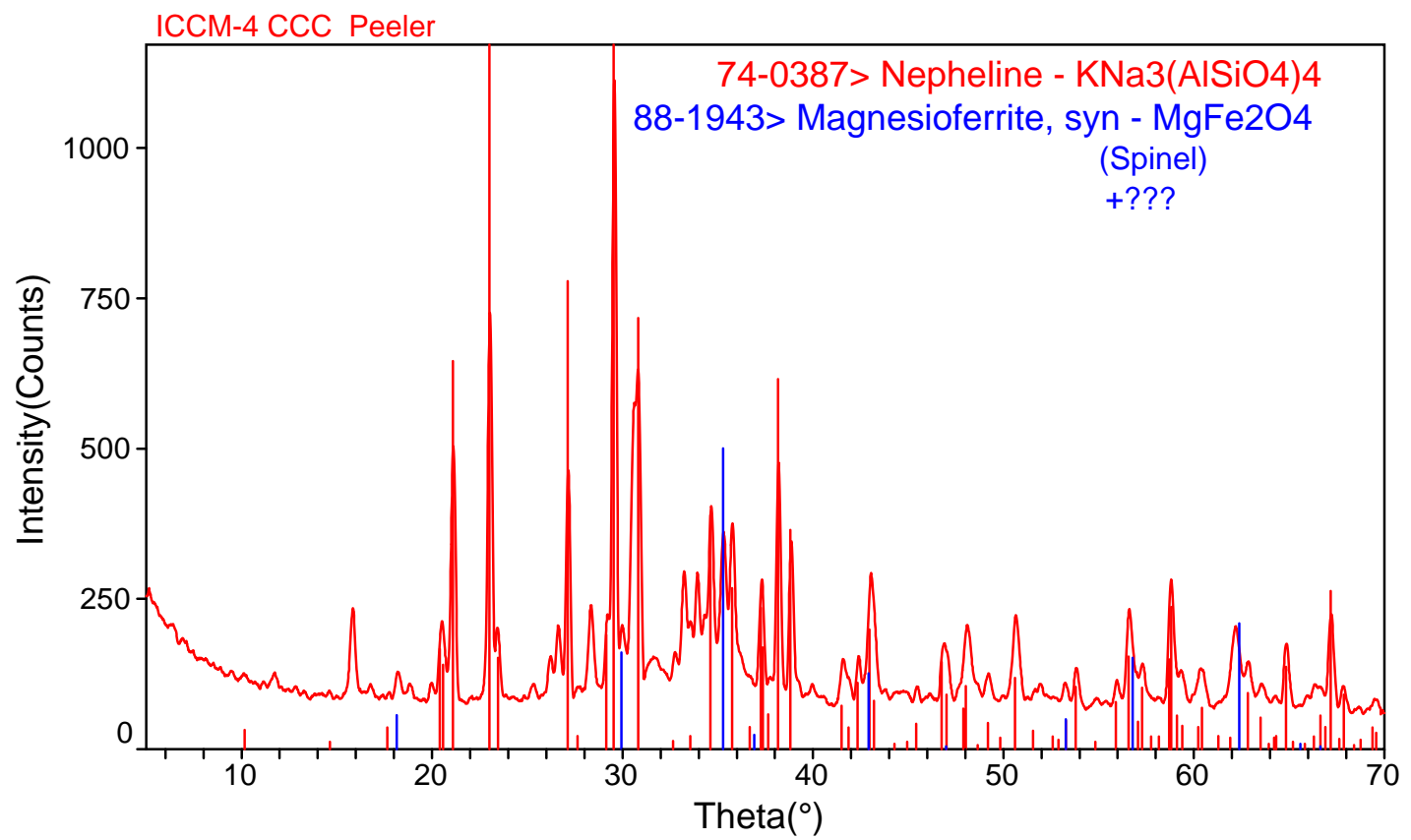

Figure B.8. XRD Results of ICCM-4 CCC. 


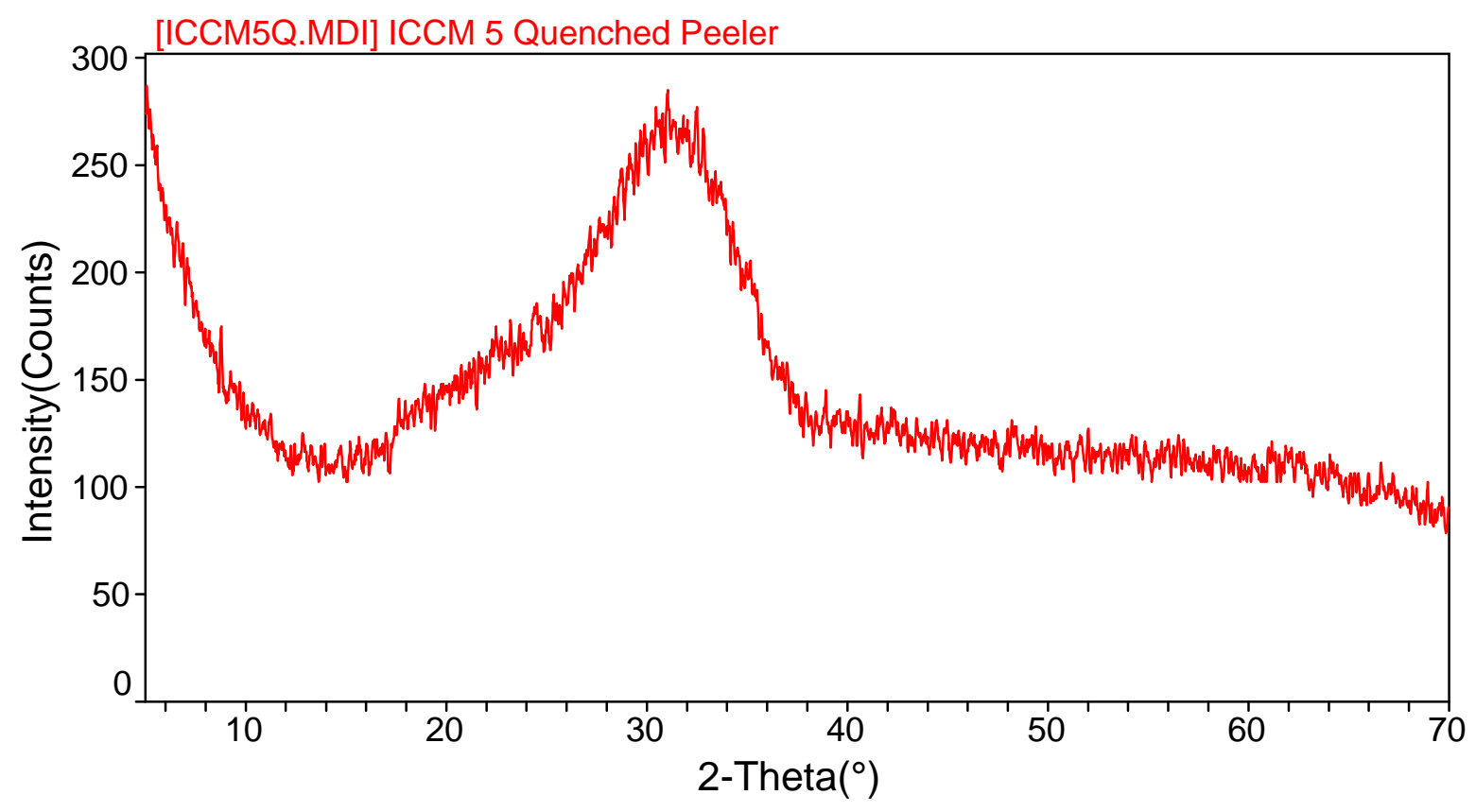

Figure B.9. XRD Results of ICCM-5 Quenched.

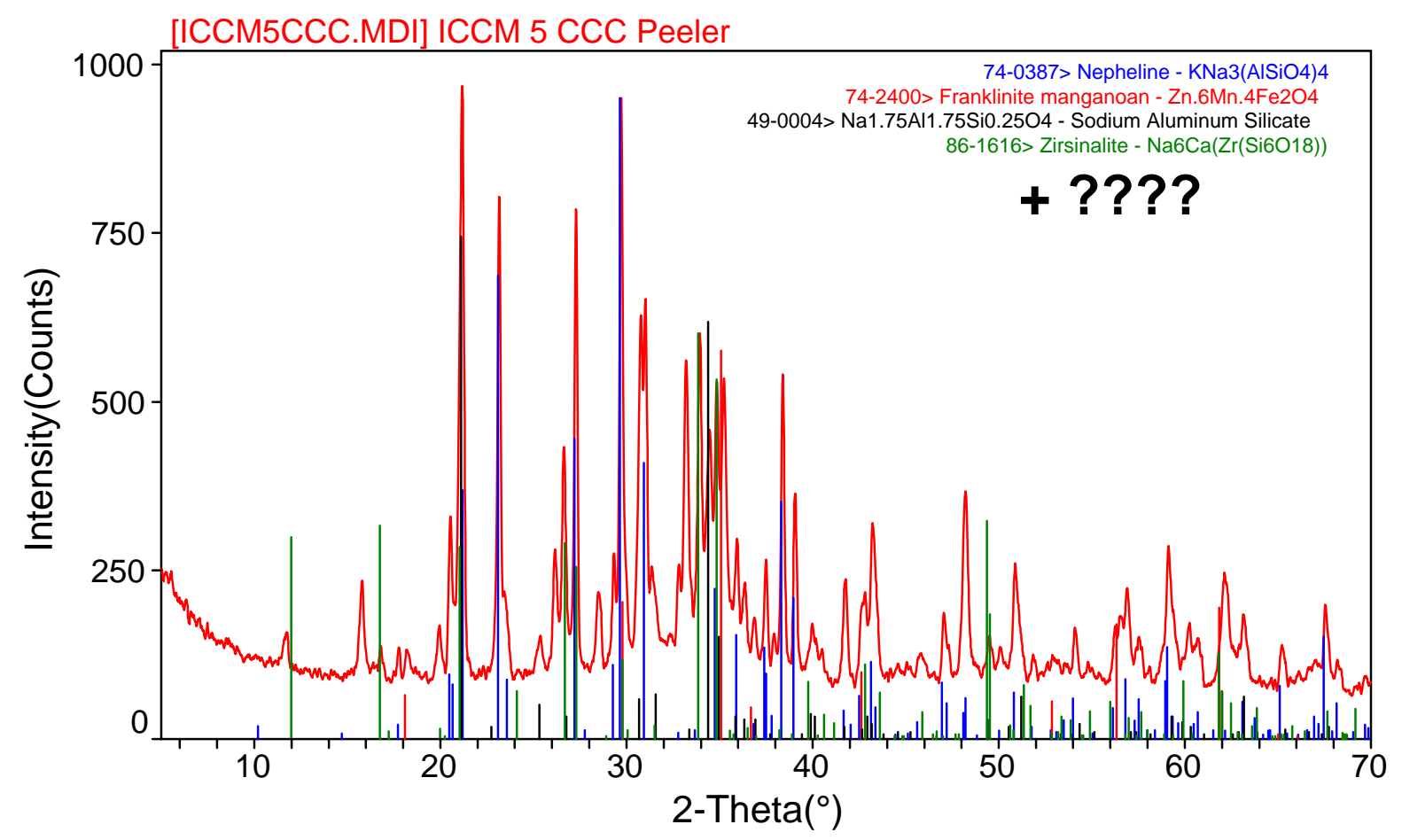

Figure B.10. XRD Results of ICCM-5 CCC. 


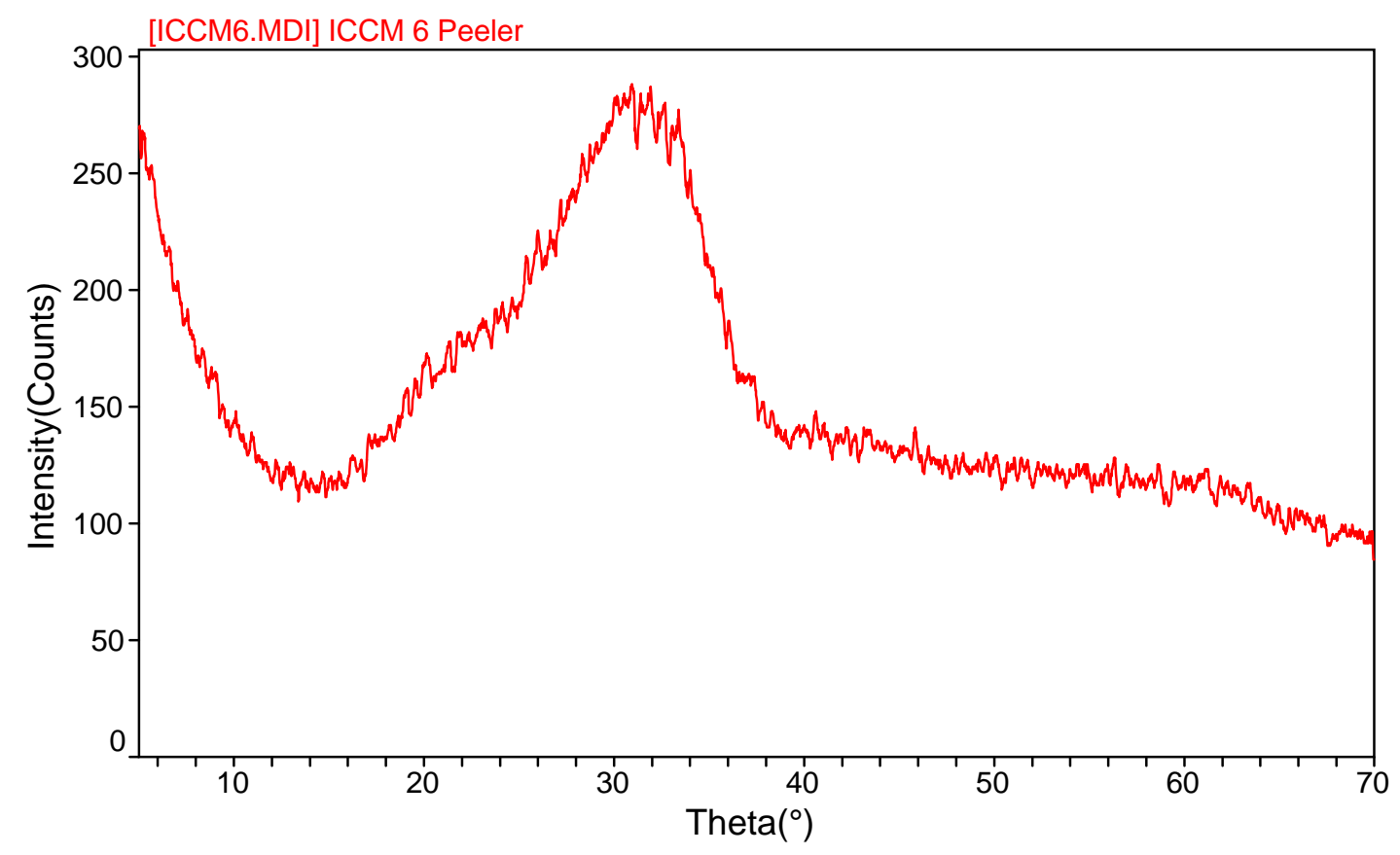

Figure B.11. XRD Results of ICCM-6 Quenched.

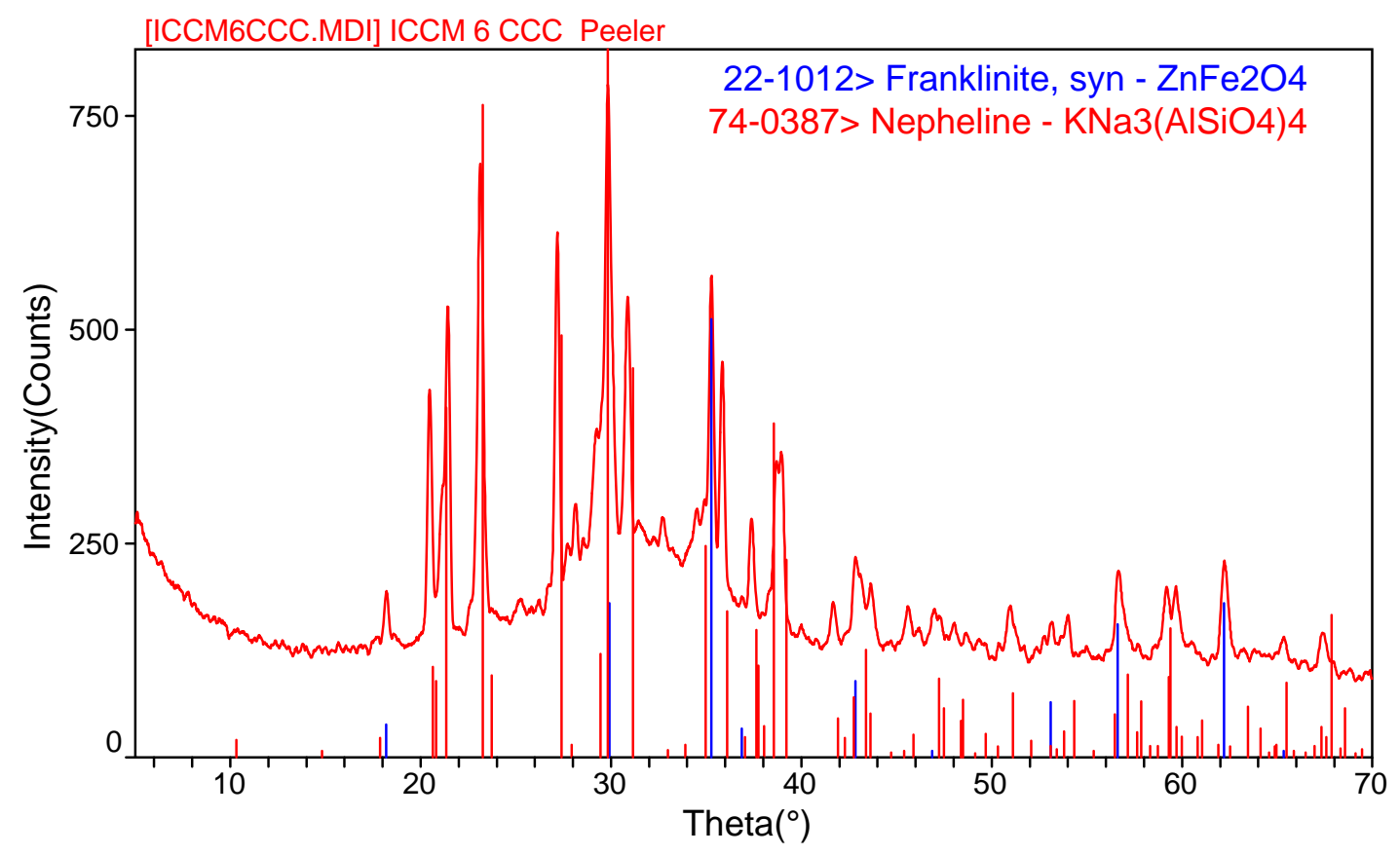

Figure B.12. XRD Results of ICCM-6 CCC. 


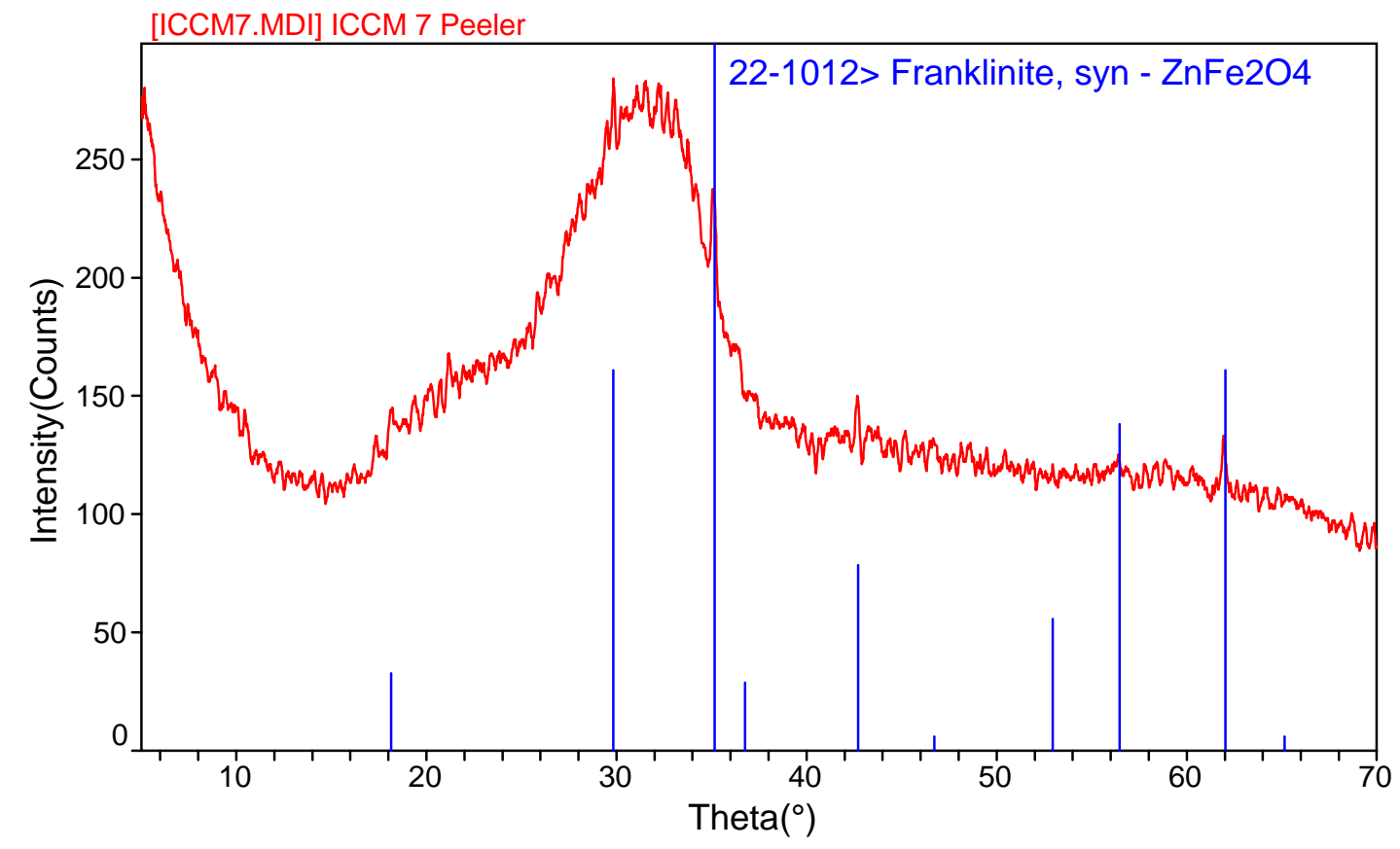

Figure B.13. XRD Results of ICCM-7 Quenched.

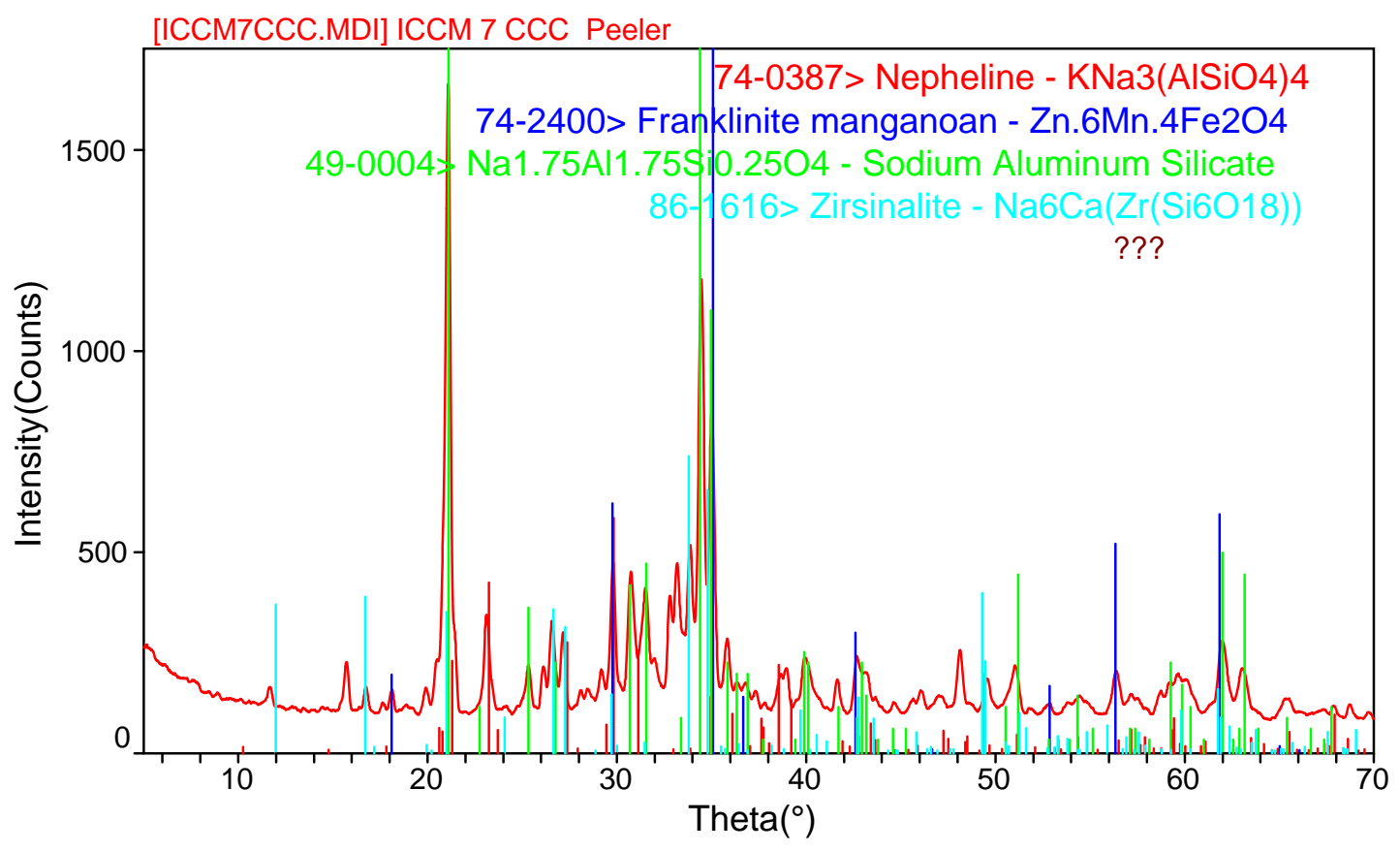

Figure B.14. XRD Results of ICCM-7 CCC. 


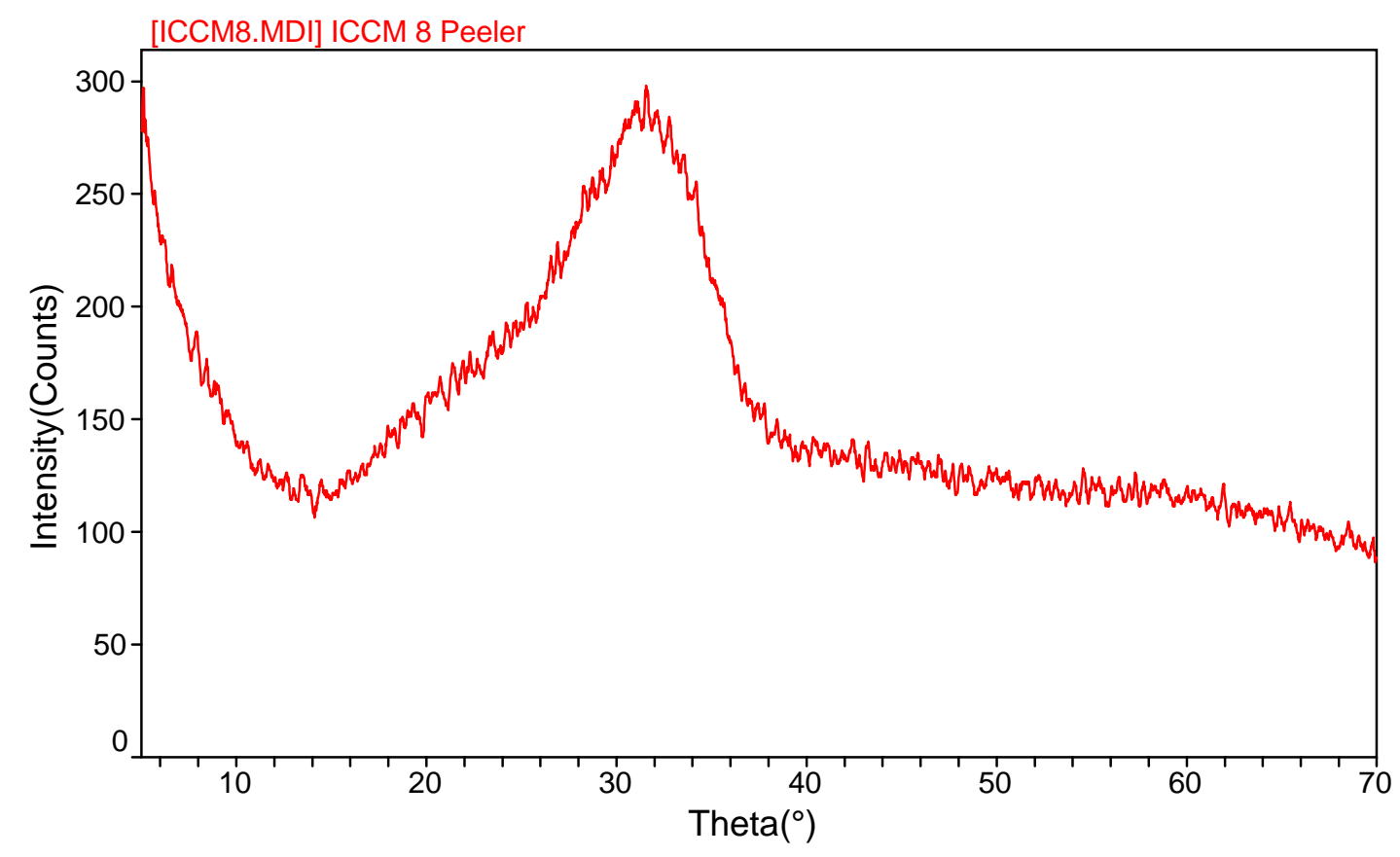

Figure B.15. XRD Results of ICCM-8 Quenched.

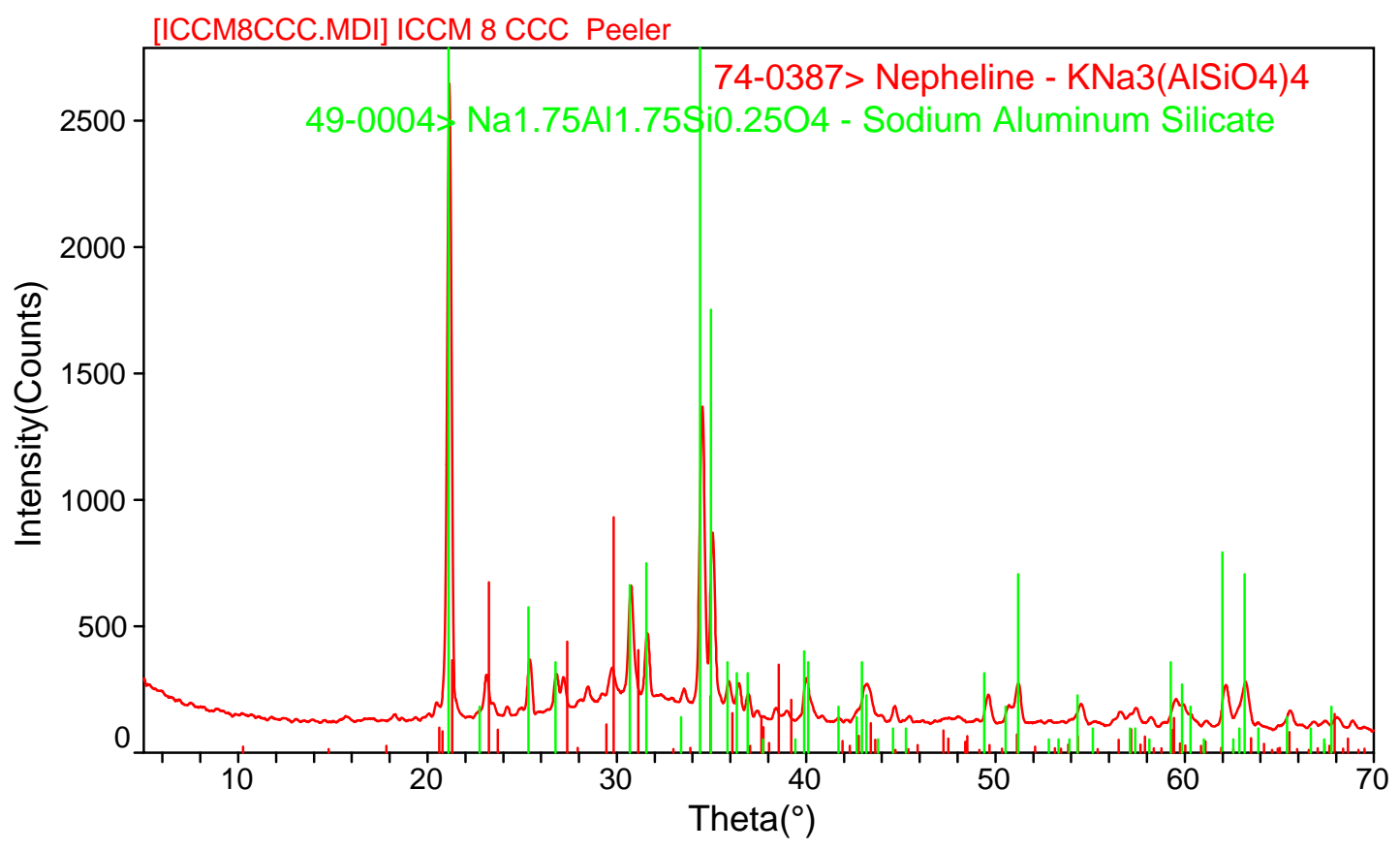

Figure B.16. XRD Results of ICCM-8 CCC. 


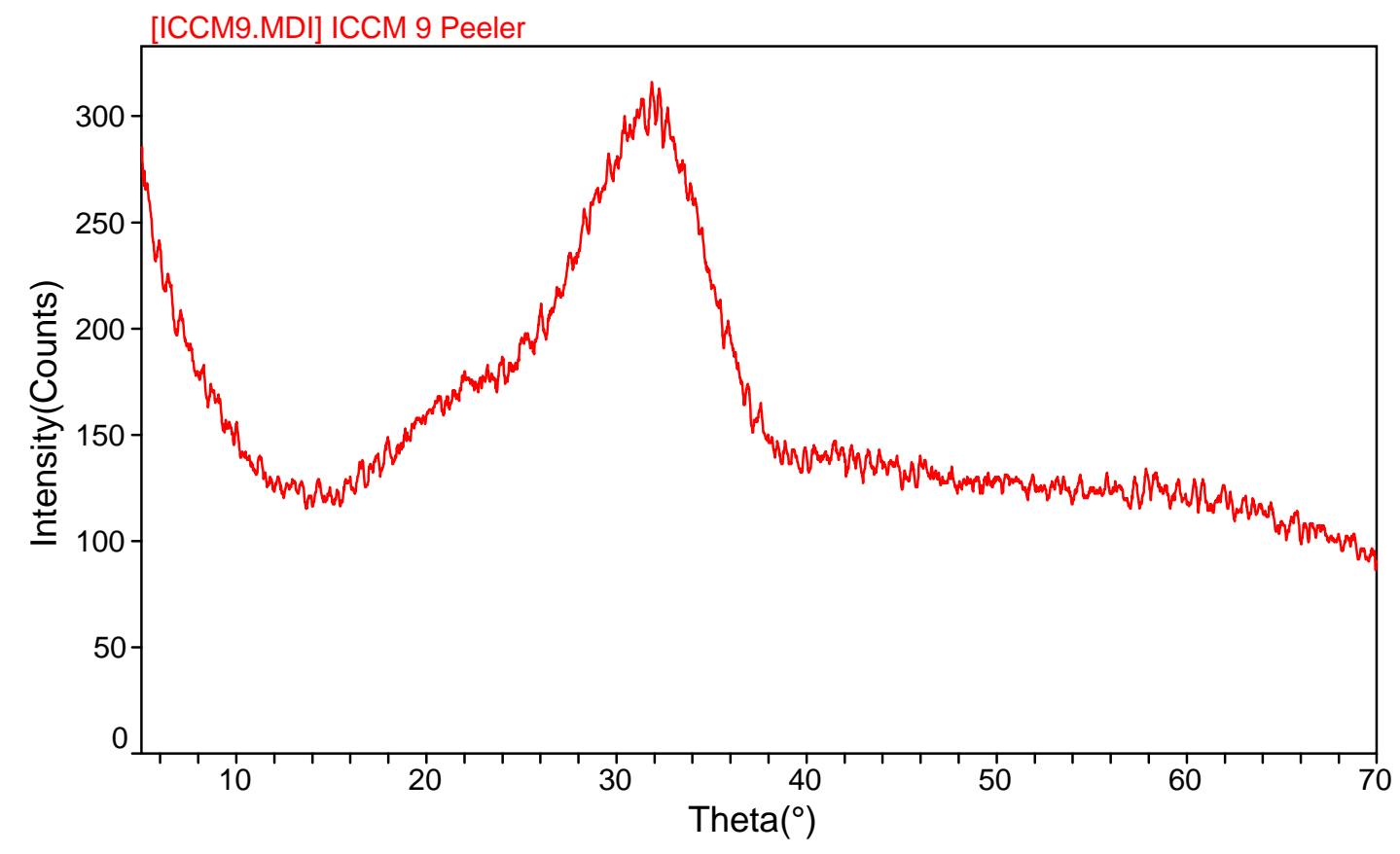

Figure B.17. XRD Results of ICCM-9 Quenched.

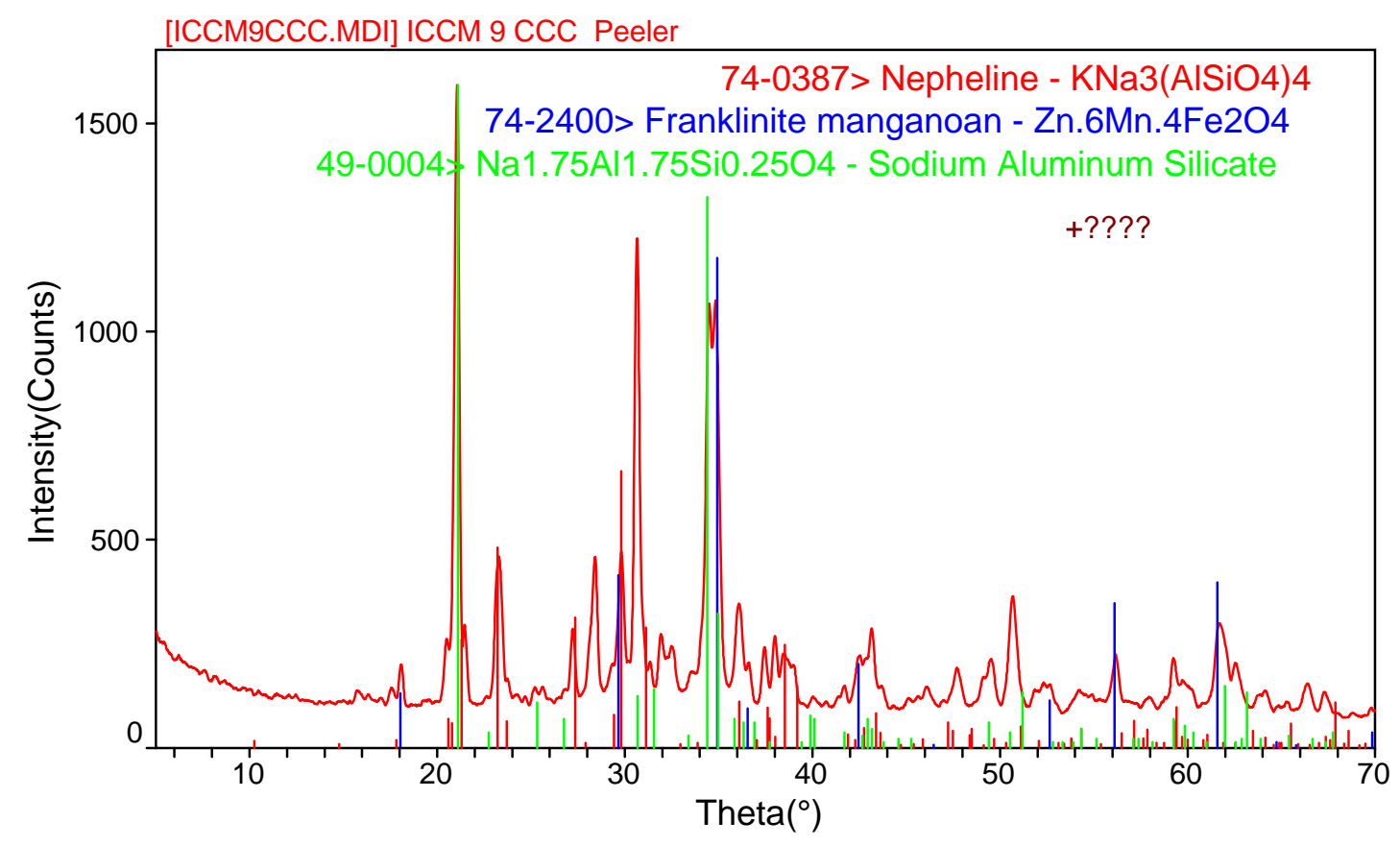

Figure B.18. XRD Results of ICCM-9 CCC. 


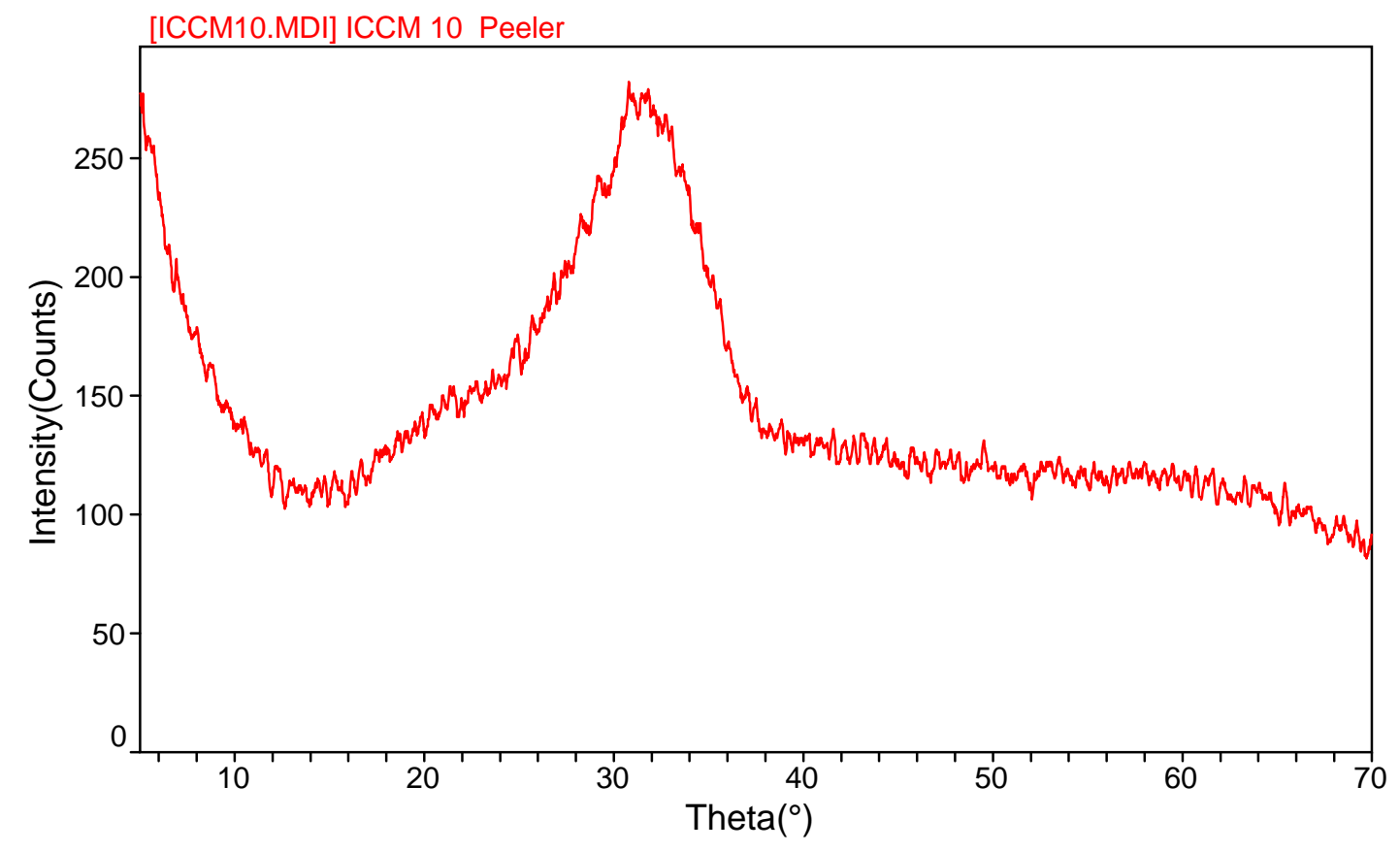

Figure B.19. XRD Results of ICCM-10 Quenched.

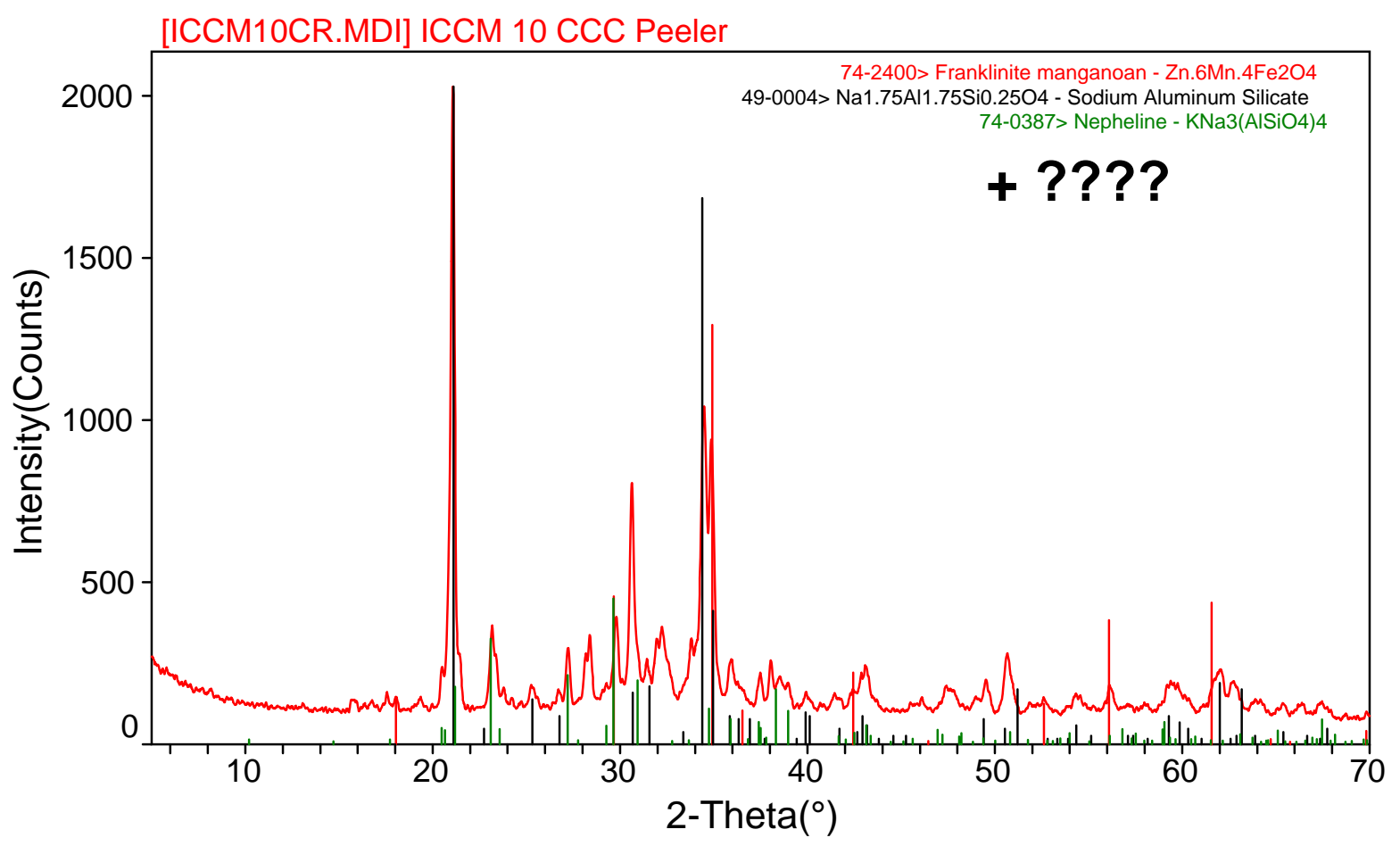

Figure B.20. XRD Results of ICCM-10 CCC. 


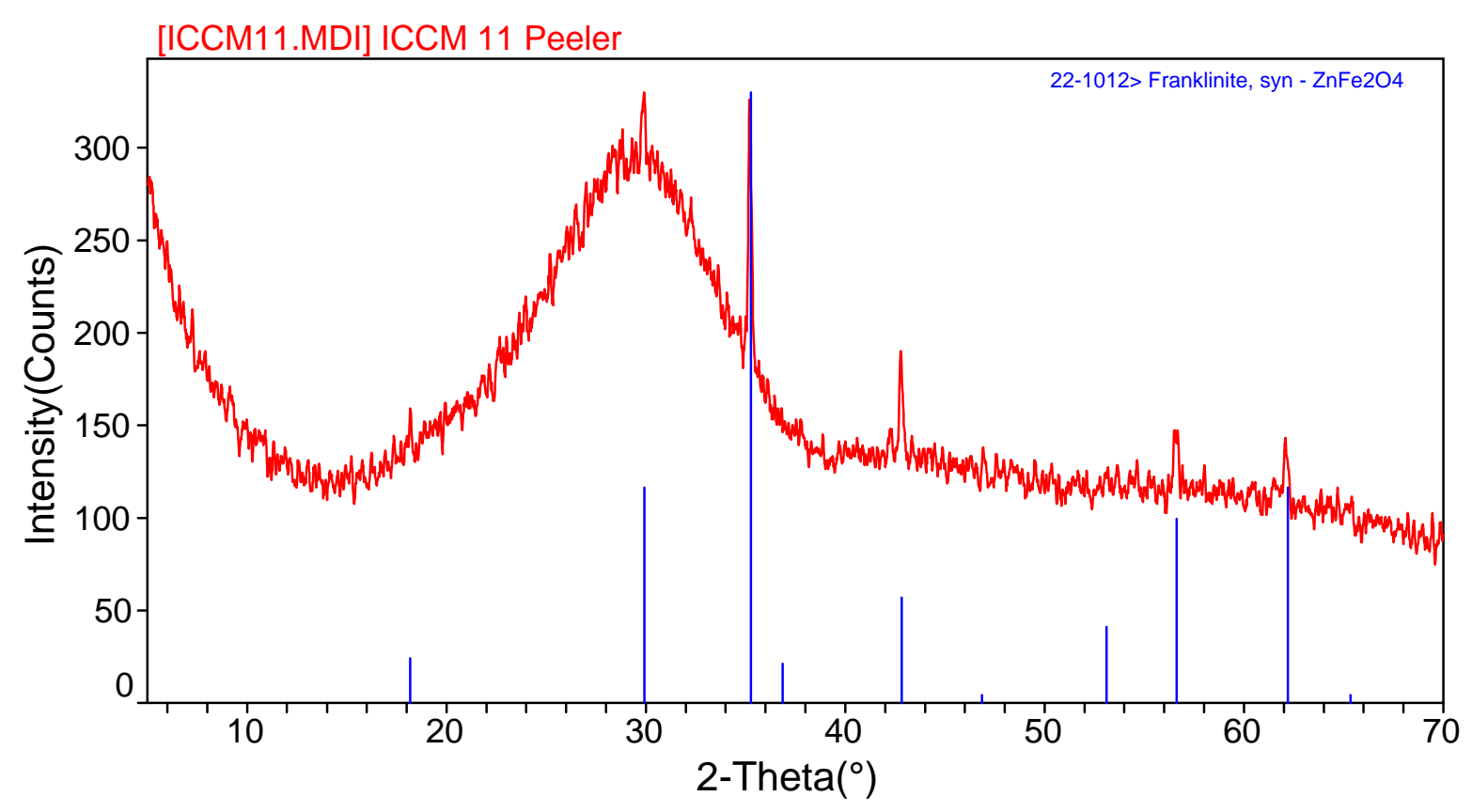

Figure B.21. XRD Results of ICCM-11 Quenched.

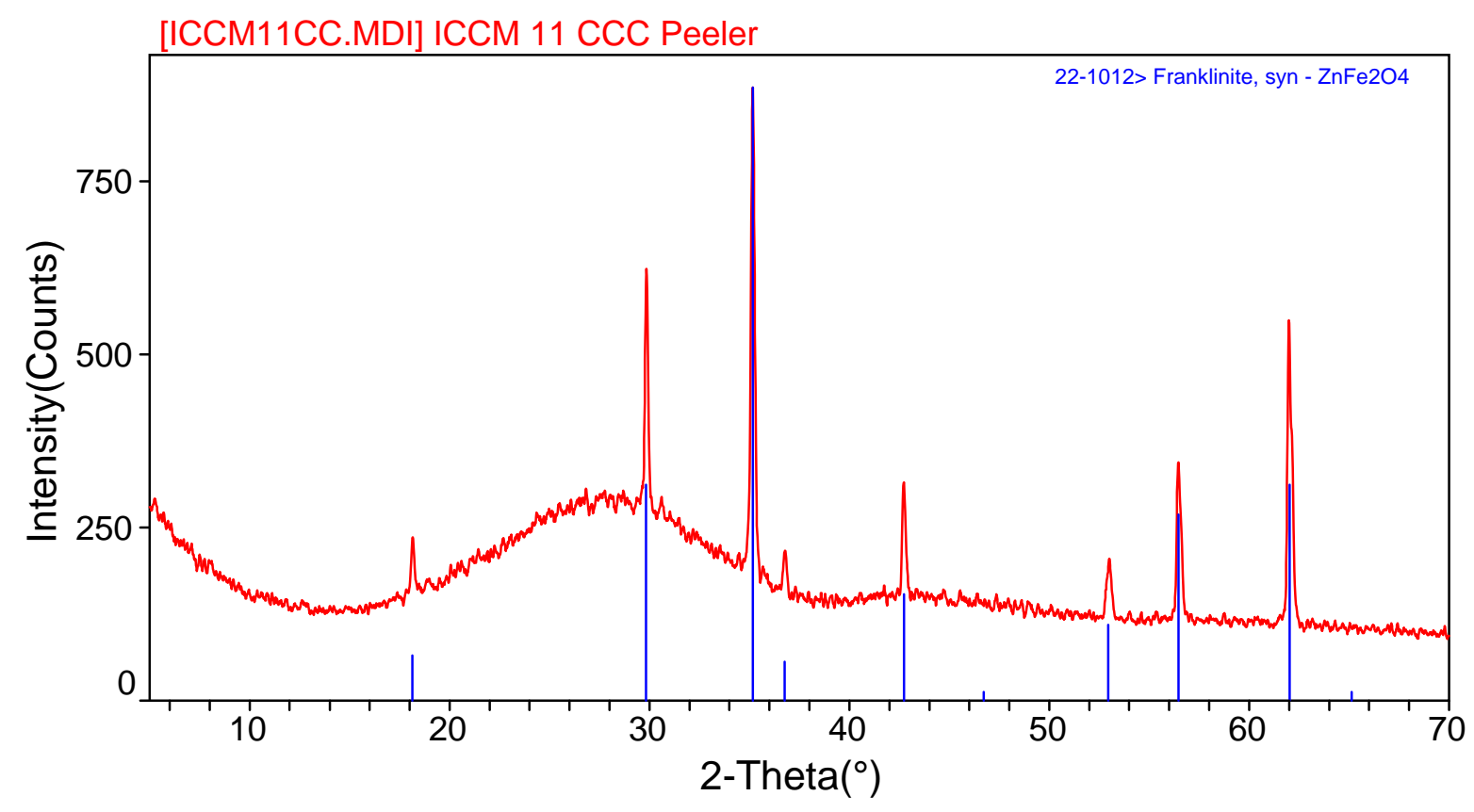

Figure B.22. XRD Results of ICCM-11 CCC. 


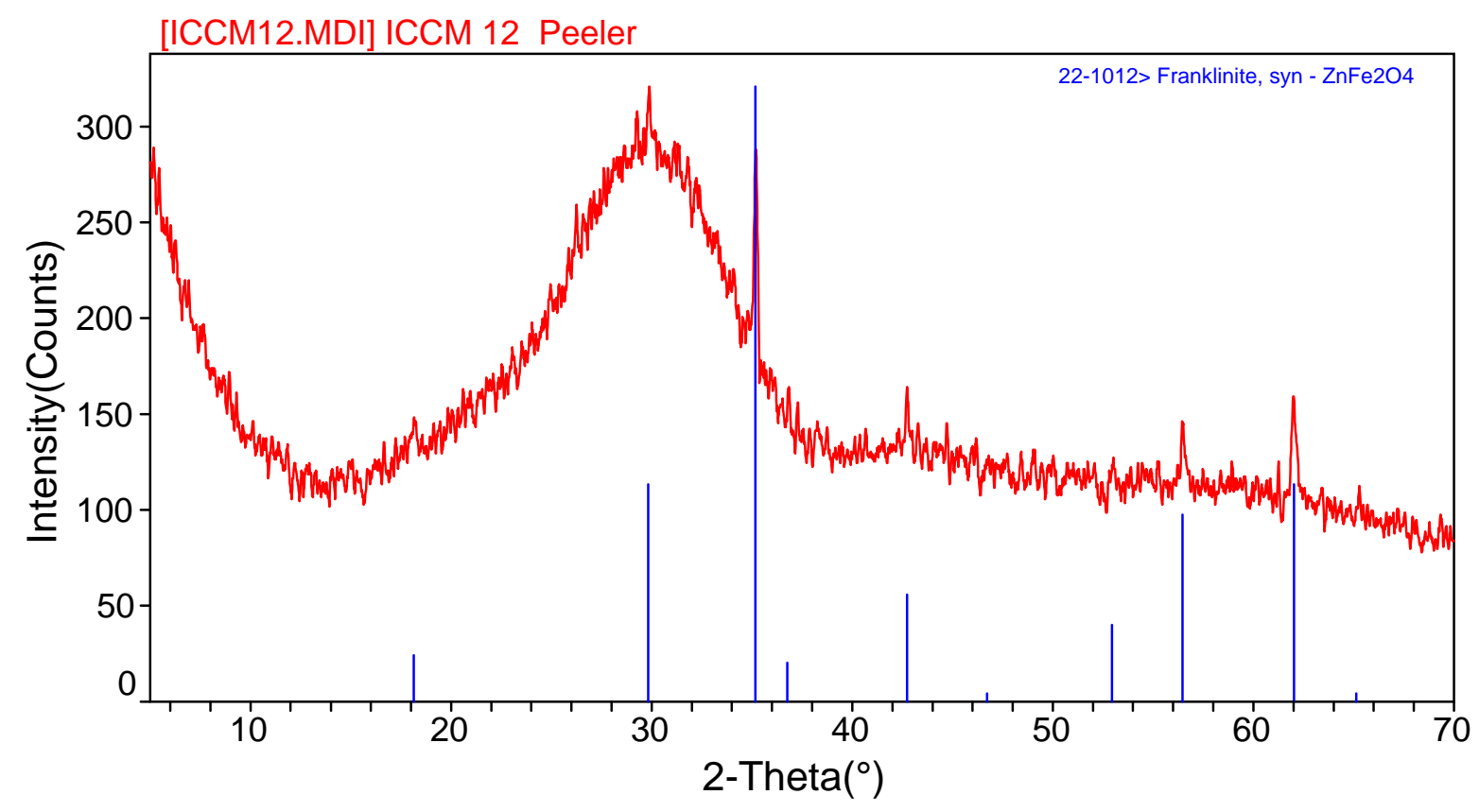

Figure B.23. XRD Results of ICCM-12 Quenched.

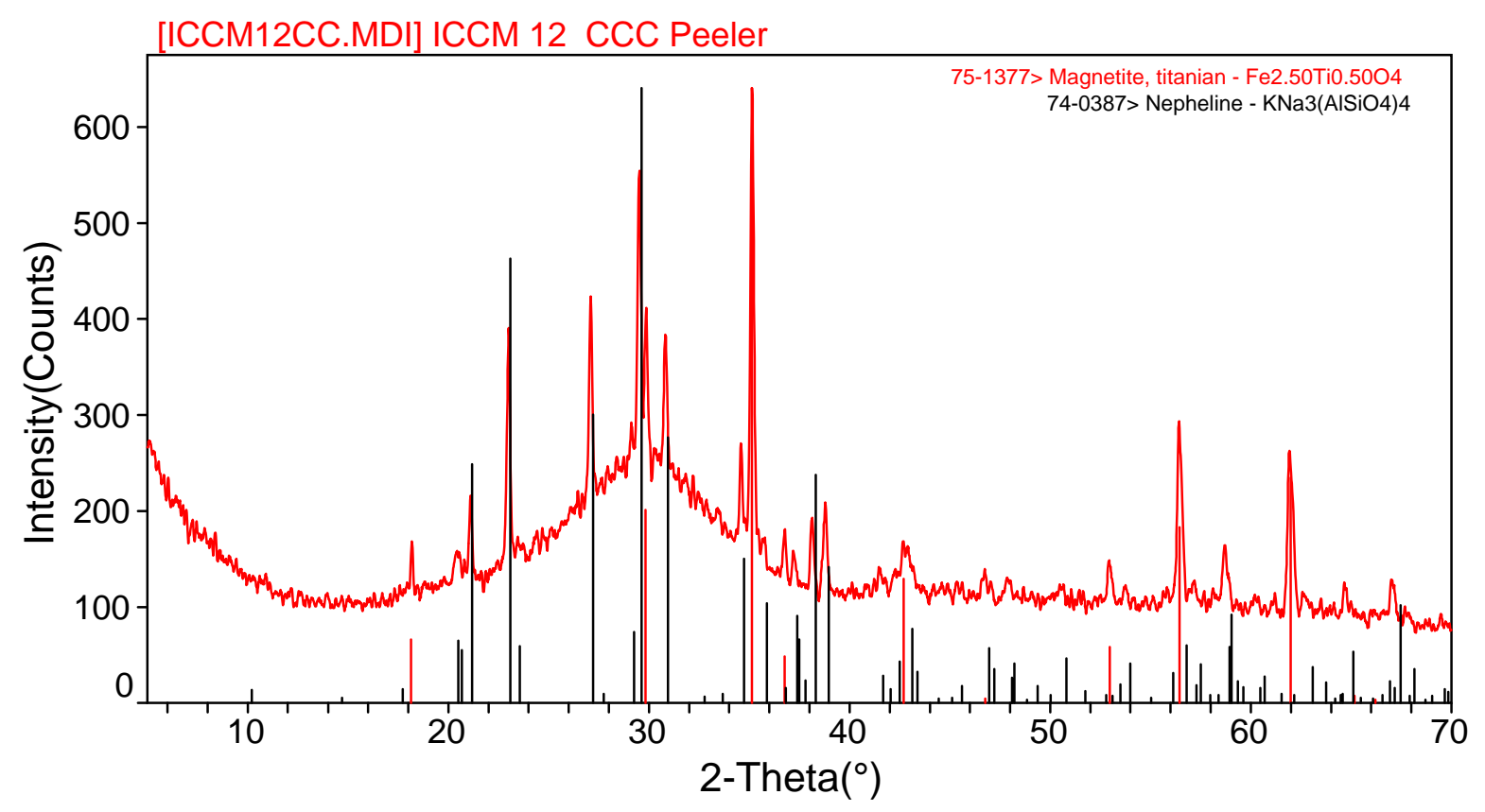

Figure B.24. XRD Results of ICCM-12 CCC. 


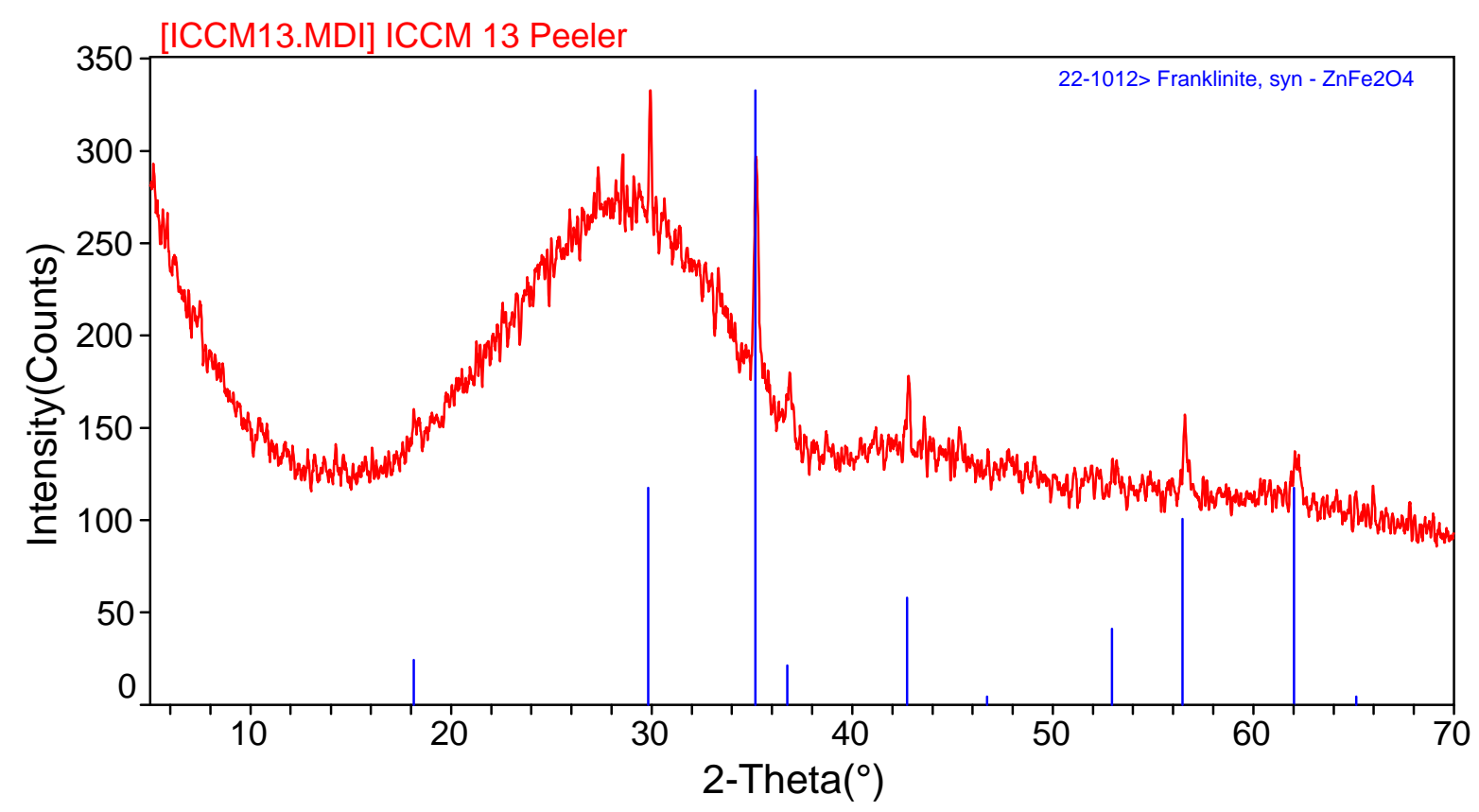

Figure B.25. XRD Results of ICCM-13 Quenched.

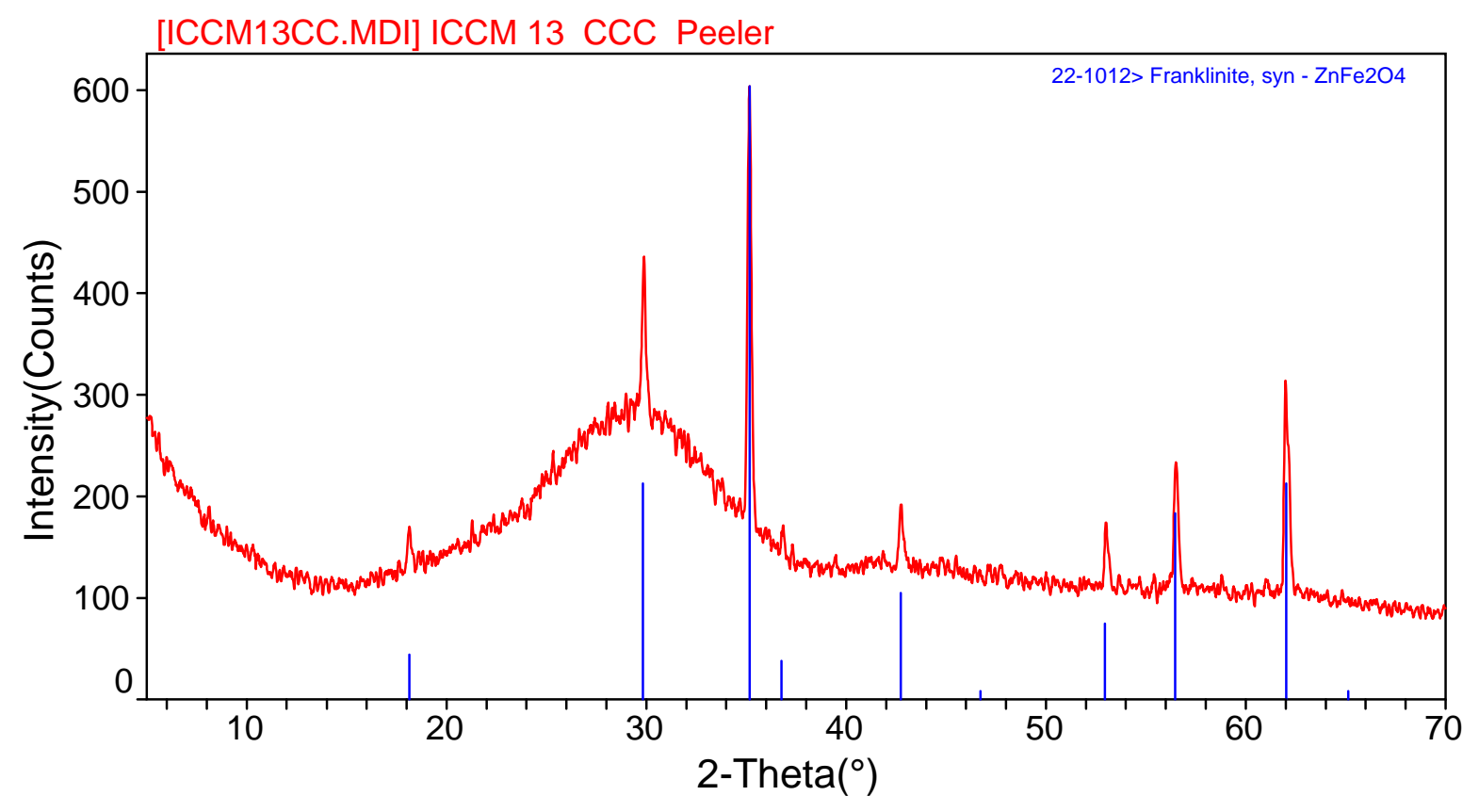

Figure B.26. XRD Results of ICCM-13 CCC. 


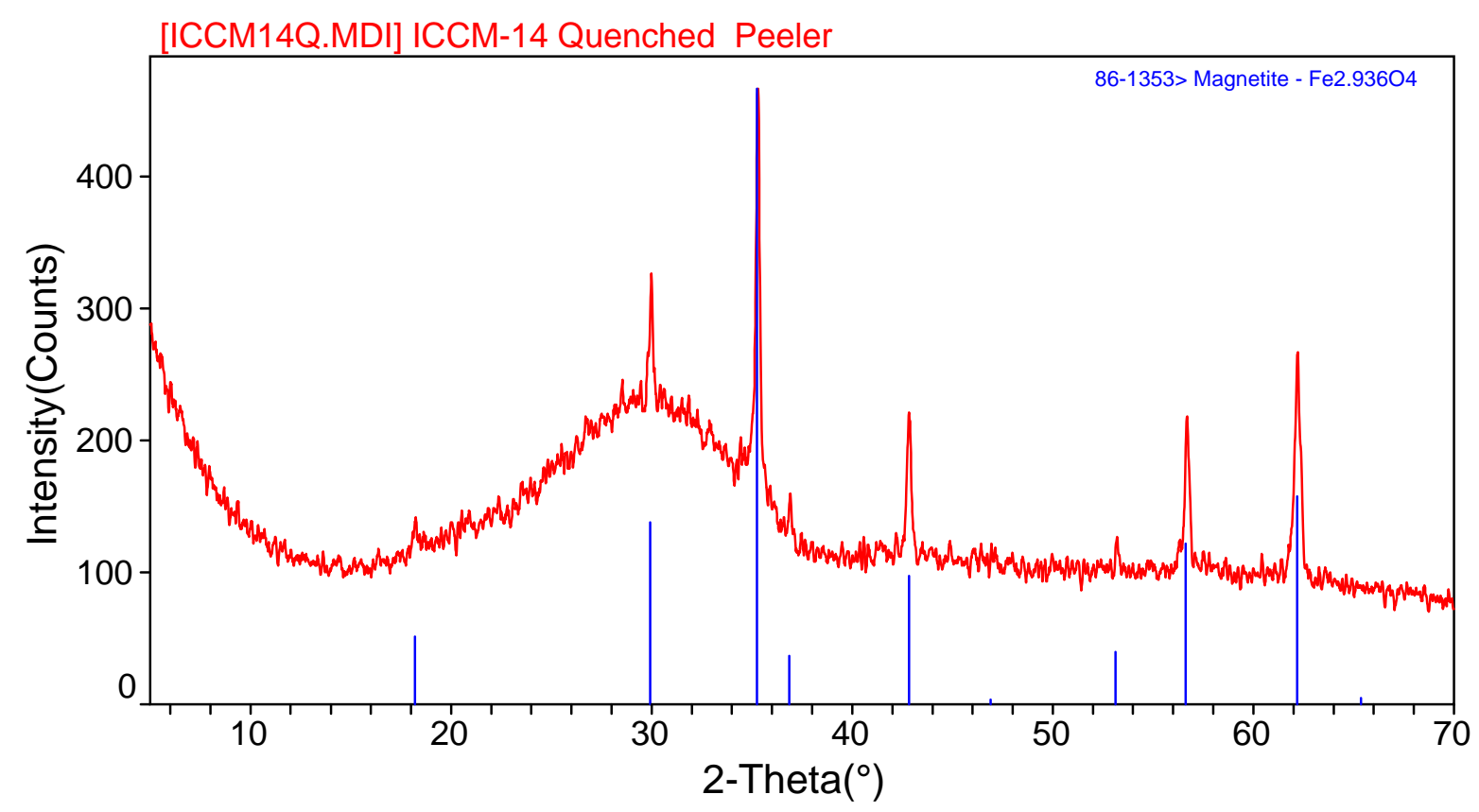

Figure B.27. XRD Results of ICCM-14 Quenched.

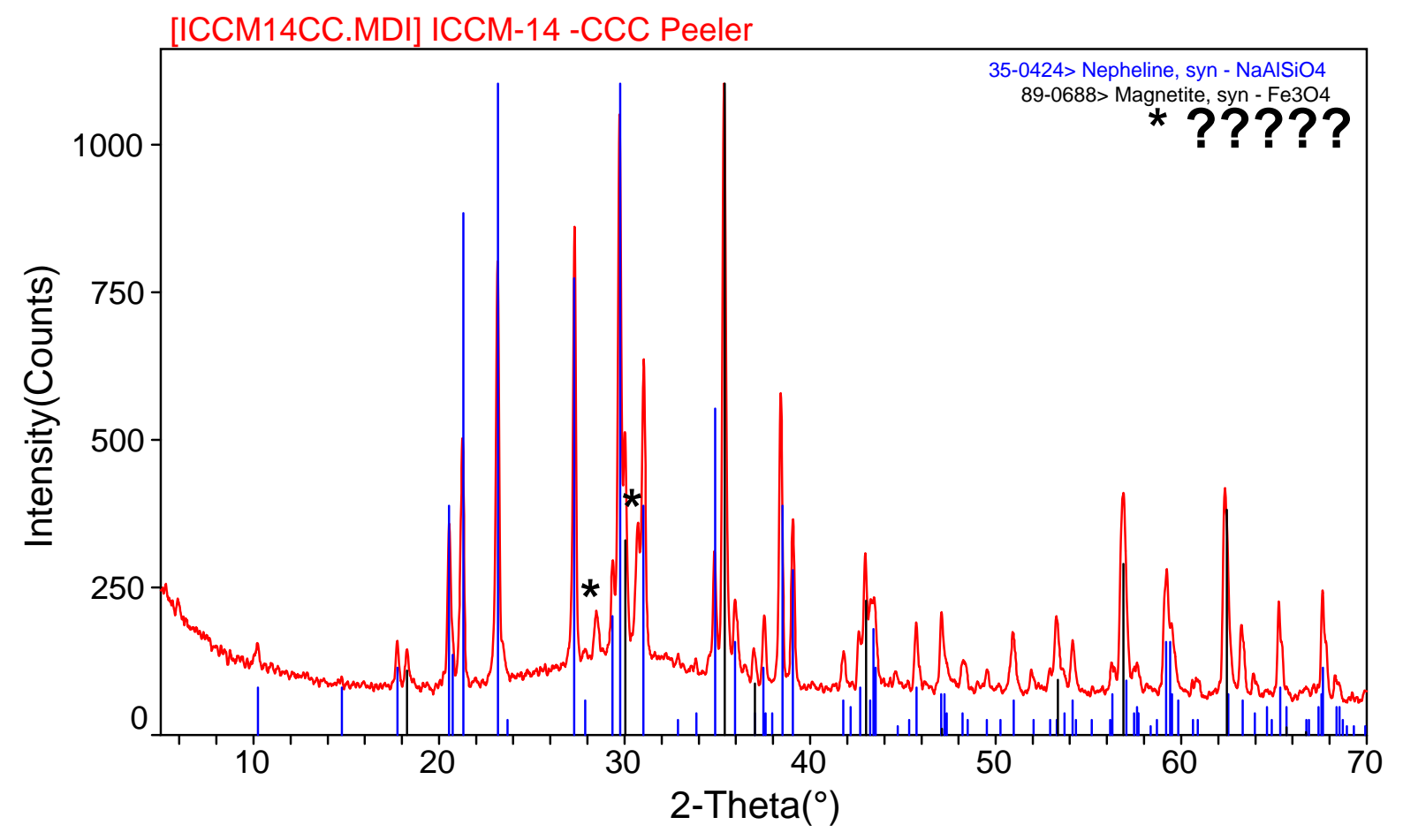

Figure B.28. XRD Results of ICCM-14 CCC. 


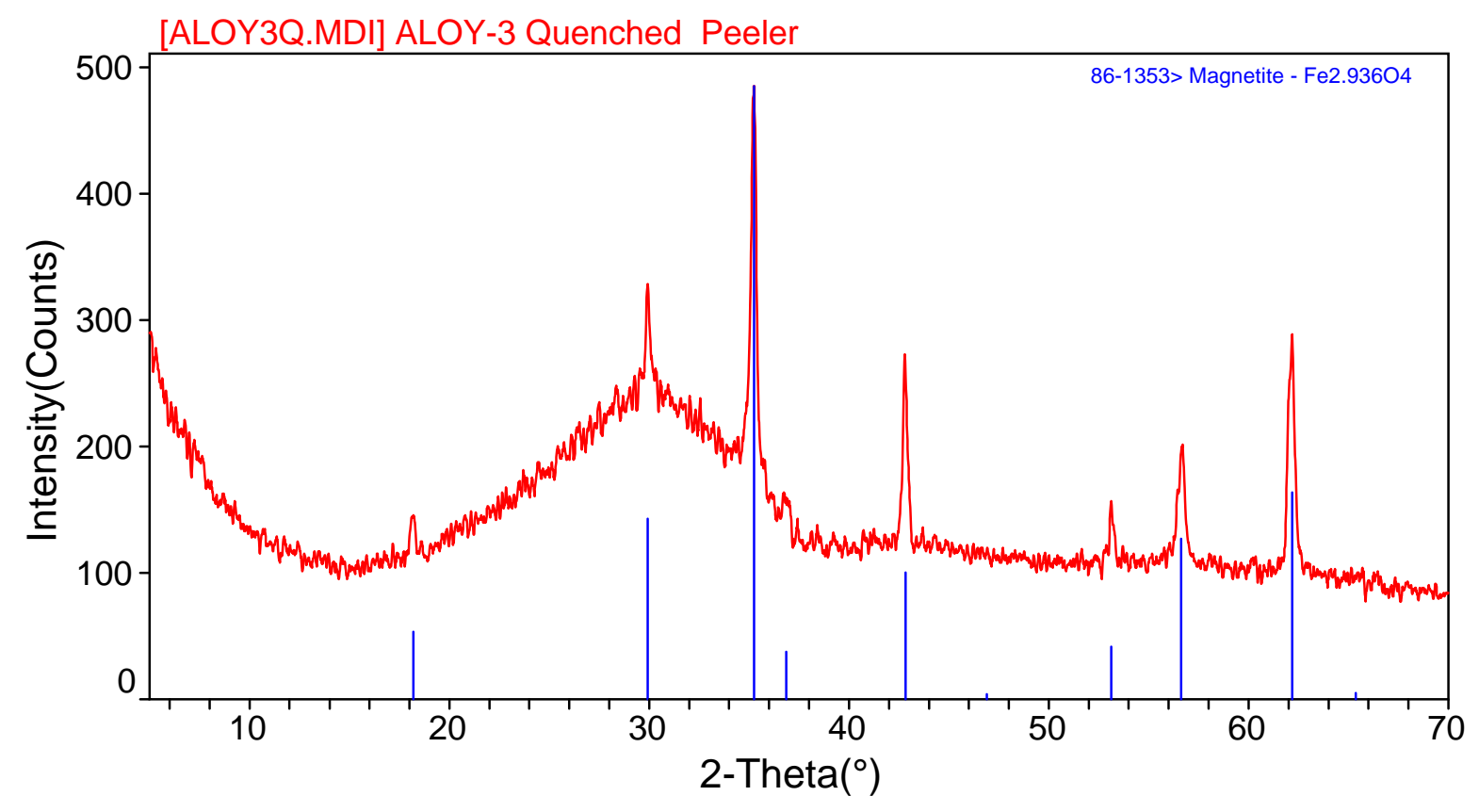

Figure B.29. XRD Results of Aloy-3 Quenched.

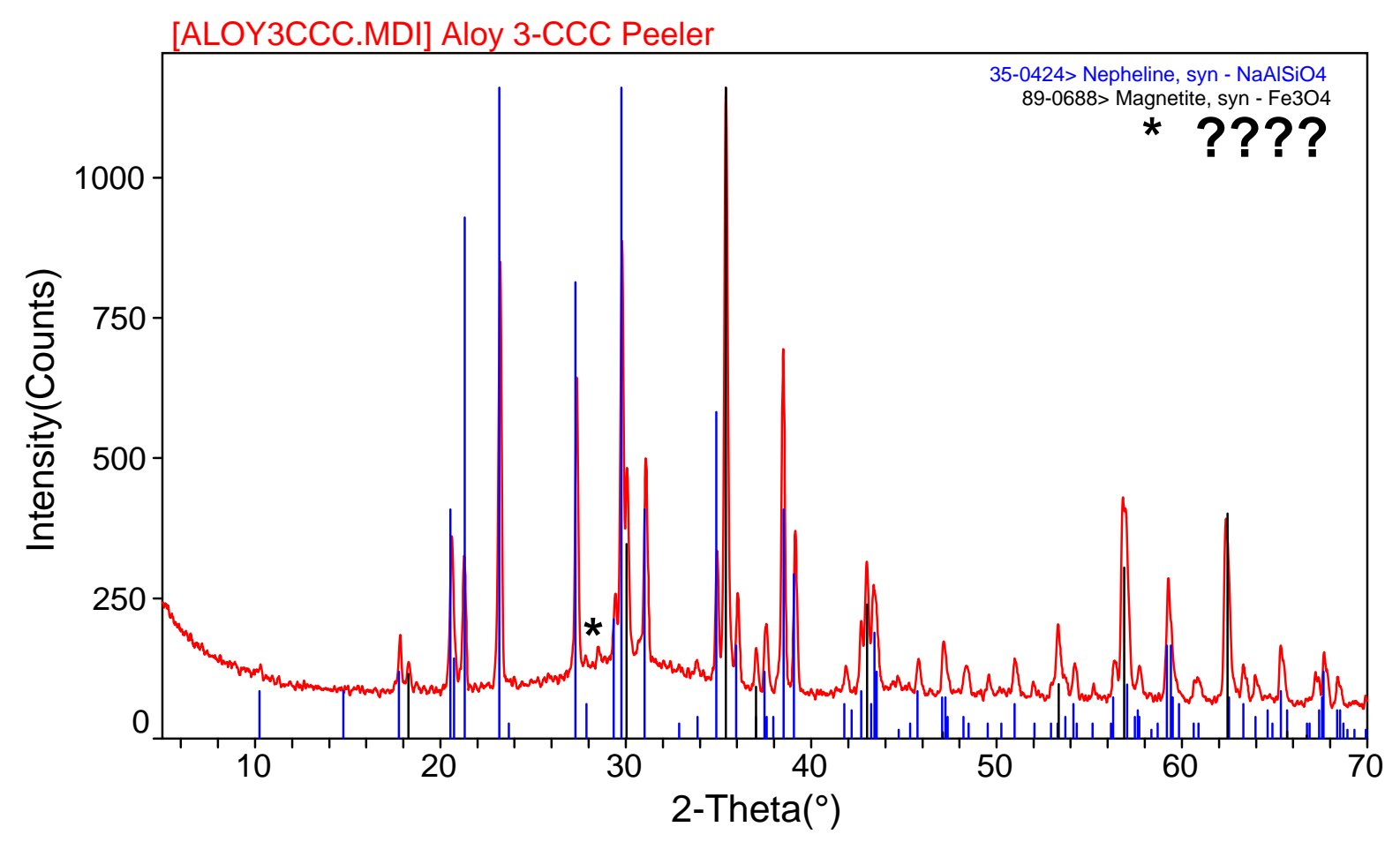

Figure B.30. XRD Results of Aloy-3 CCC. 
Immobilization Technology Section

WSRC-TR-2002-00426

Savannah River Technology Center

Rev. 0

Westinghouse Savannah River Company

\section{Appendix C}

\section{Viscosity Data for ICCM-1 and ICCM-2}


Table C.1. Viscosity Data for ICCM-1

(to convert Poise to Pa-s divide by 10)

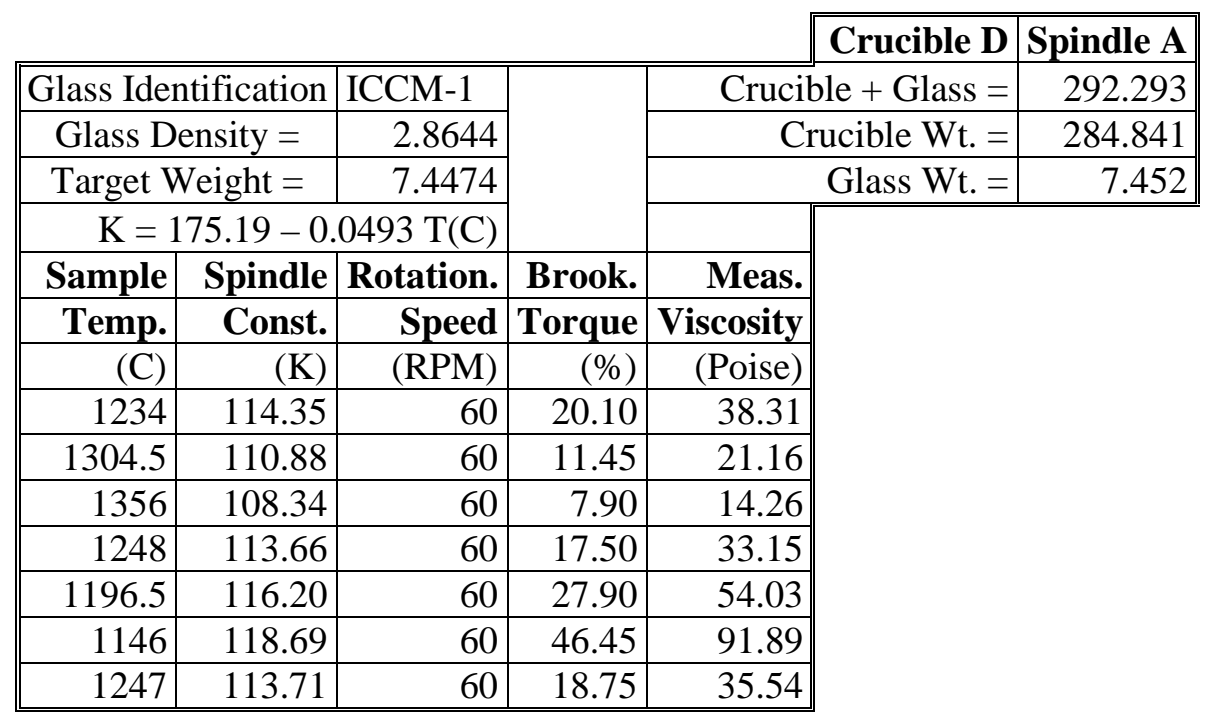

Table C.2. Viscosity Data for ICCM-2

(to convert Poise to Pa-s divide by 10)

Crucible D Spindle A

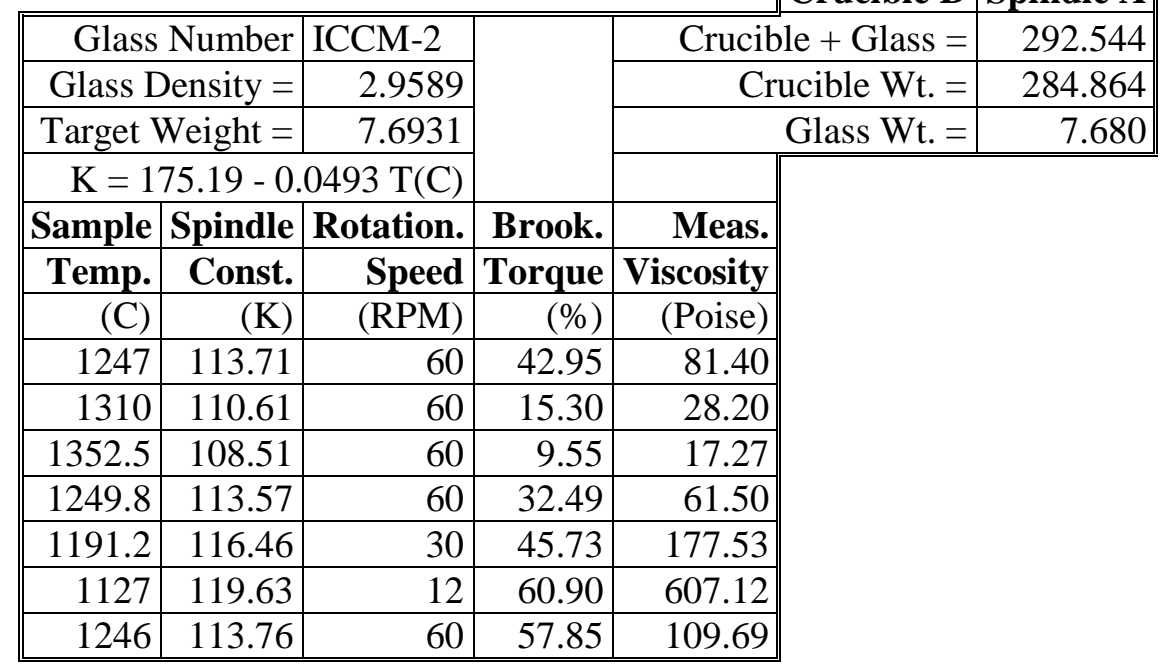

